\title{
ARTICLES
}

\section{THE GATEKEEPER OF THE ICC: PROSECUTORIAL STRATEGIES FOR SELECTING SITUATIONS AND CASES AT THE INTERNATIONAL CRIMINAL COURT}

\author{
LOVISA BÅDAGÅRD \& MARK KLAMBERG*
}

\begin{abstract}
The Office of the Prosecutor (OTP) of the International Criminal Court (ICC) has a unique role in the proceedings before the Court. It is the organ primarily tasked with choosing among the numerous situations and cases under the Court's jurisdiction. The legal criteria for situation and case selection, provided in the Rome Statute and related regulations, are relatively open as to allow the Prosecutor a considerable degree of discretion. In order to guide this discretion, the Office of the Prosecutor has developed certain policies and strategies. Prosecutorial policy and strategy stands, almost by definition, at a crossroads between law and politics. This Article identifies strategic choices of the OTP in situation and case selection and analyzes them in relation to the ICC's objectives. There are tensions between the need for predictability and legal certainty on the one hand and for pragmatism and case-by-case flexibility on the other hand. The Article finds that the OTP is downplaying its own discretion by emphasizing the legalistic and apolitical character of its decision-making and bringing the objectives of ending impunity, preventing crimes, and providing redress to victims to the fore. The objectives of restoring peace and security and of contributing to a historical record have been secondary to the OTP's strategic choices.
\end{abstract}

I. INTRODUCTION . . . . . . . . . . . . . . . . . . . . . . . . . . . . . . 642

II. ReSEARCH Methodology . . . . . . . . . . . . . . . . . . . . . . . 643

III. Background: A Unique Prosecutor. . . . . . . . . . . . . . . . 647

A. Prosecutorial Discretion in General . . . . . . . . . . . . . 647

B. The Prosecutor of the ICC . . . . . . . . . . . . . 648

IV. The Objectives of The ICC. . . . . . . . . . . . . . . . . . . 649

A. Ending Impunity. . . . . . . . . . . . . . . . . . . . . . . . . . . 650

B. Preventing Crimes ................... 651

* Lovisa Bådagård received her L.L.M. degree from Uppsala University. She is currently a Law Clerk at the Uppsala District Court. Mark Klamberg is an Associate Professor at Stockholm University, where he received his LL.D. Klamberg has an LL.M. from Raoul Wallenberg Institute and received his Candidate of Law degree from Lund University. ( 2017, Lovisa Bådagård \& Mark Klamberg. 
C. Improving Respect for International Law . . . . . . . . . . . 653

D. Restoring International Peace and Security. . . . . . . . . . . 654

E. Creating a Historical Record. . . . . . . . . . . . . . . . 656

F. Providing Redress for Victims . . . . . . . . . . . . 657

G. Broad and Interrelated Objectives . . . . . . . . . . . . 658

V. The Legal Framework for Situation and Case Selection . . . 659

A. Situations and Cases: What is the Difference? . . . . . . . 659

B. Trigger Mechanisms. .................... 661

1. State Referrals ................... 661

2. Security Council Referrals . . . . . . . . . . . . 661

3. Proprio Motu Investigations. . . . . . . . . . . . . . . 662

C. The Preliminary Examination Phase . . . . . . . . . . . 663

1. Reasonable Basis for Investigation . . . . . . . . . . 663

2. Evidence and Jurisdiction . . . . . . . . . . . . 665

3. Admissibility of the Situation . . . . . . . . . . . . . 665

a. Complementarity and Ne Bis in Idem . . . . . . . . . . 666

b. Gravity...................... 668

4. The Interests of Justice. . . . . . . . . . . . . 670

5. The Outcome of a Preliminary Examination.... . 671

a. The Decision to Open an Investigation . . . . . . . . 671

b. The Decision Not to Open an Investigation . . . . . . 672

6. Security Council Deferral. . . . . . . . . . . . . . 674

D. The Investigation Phase . . . . . . . . . . . . . . . . . . 674

1. Preliminary Rulings Regarding Admissibility. . . . 674

2. Duties and Powers of the Prosecutor While

Conducting the Investigation. . . . . . . . . . . . . . . . 675

3. Selecting Cases for Prosecution . . . . . . . . . . 675

a. The Parameters of Selection . . . . . . . . . . . 675

b. Sufficient Basis for a Warrant of Arrest or Summons to Appear. . . . . . . . . . . . . . . . . 676

c. The Admissibility of Cases . . . . . . . . . . . 676

4. Cases and the Interests of Justice . . . . . . . . . 679

5. The Outcome of an Investigation . . . . . . . . 680

a. The Decision to Prosecute. . . . . . . . . . . . . 680

b. Decision Not to Prosecute . . . . . . . . . . . . . . . 681

E. Summary: What Room is There for Discretion in Situation and Case Selection? . . . . . . . . . . . . . . . . . . . 682

1. Situation Selection . . . . . . . . . . . . . . . . . . 682

2. Case Selection ... . . . . . . . . . . . . . . . . . 684

VI. The ICG Prosecutorial Strategy and Policy . . . . . . . . . . . 684

A. Inventory of Policy and Strategy Documents . . . . . . . . . 684

B. General Content of the Strategy and Policy Documents . . . . 686 
1. Initial Policy Paper (2003) . . . . . . . . . . . . 686

2. Strategy Documents . . . . . . . . . . . . . . . 687

a. Strategy Documents under Luis Moreno Ocampo (2006-2012). . . . . . . . . . . . . 687

b. Strategy Documents under Fatou Bensouda (2012-2018). . . . . . . . . . . . . . . 689

3. Policy Papers . . . . . . . . . . . . . . . . . . 691

a. Policy Paper on the Interests of Justice (2007). . . . 691

b. Policy Paper on Victims' Participation (2010) .... 693

c. Policy Paper on Preliminary Examinations (2013). . . 694

d. Policy Paper on Sexual and Gender-Based Crimes (2014) . . . . . . . . . . . . . . . . 695

e. Draft Policy Paper on Case Selection and Prioritization (2016). . . . . . . . . . . . . . . . . . 695

VII. Analysis of Strategic CHOices . . . . . . . . . . . . . . . . 698

A. Strategic Choice 1: Presumption for the Interests of Justice. . . 698

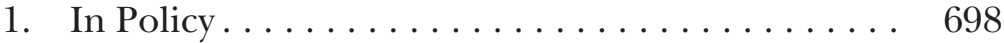

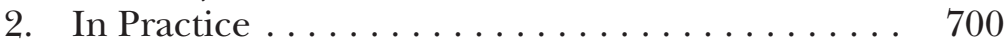

3. Analysis ................. 703

a. A Duty to Investigate and Prosecute . . . . . . . 703

b. An Apolitical Prosecutor . . . . . . . . . . 705

c. The Interests of Justice vs. the Interests of Peace. . . . 708

d. Conclusions: Focusing on "What A Court Does Best"................... 710

B. Strategic Choice 2: Relative Gravity in Situation Selection . . . 712

1. In Policy . . . . . . . . . . . . . . . . . 712

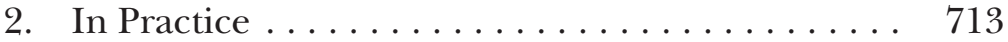

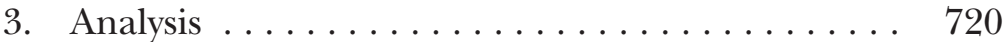

a. Gravity, Neutrality, and Moral Clarity . . . . . . 720

b. Painting A Broad Historical Picture . . . . . . . . . 722

c. Conclusions: Recognizing the Need for Selectivity . . 723

C. Strategic Choice 3: Focusing on High-Level Perpetrators . . . 723

1. In Policy . . . . . . . . . . . . . . . . 723

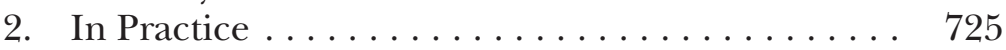

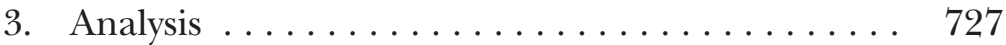

a. Ending Impunity for the Most Powerful. . . . . . . 727

b. Avoiding A Singular Focus . . . . . . . . . . . . 728

c. Conclusions: A Principally and Pragmatically Reasonable Approach . . . . . . . . . . . . . 730

VIII. Conclusion . . . . . . . . . . . . . . . . . . . 730 


\section{INTRODUCTION}

The Prosecutor of the International Criminal Court (ICC) has a unique role in the proceedings before the Court. It is the organ primarily tasked with choosing among the numerous situations and cases under the Court's jurisdiction. The legal criteria for situation and case selection, provided in the Rome Statute (the Statute) and related regulations, are relatively open as to allow the Prosecutor a considerable degree of discretion. In order to guide this discretion, the Office of the Prosecutor (OTP) has developed certain policies and strategies.

Prosecutorial policy and strategy stands, almost by definition, at a crossroads between law and politics. This may explain why prosecutorial discretion of the ICC, ever since the drafting of the Statute, ${ }^{1}$ has been a controversial issue. ${ }^{2}$ Opponents of wide discretionary powers argue that they lead to "politicization" of the Court's powers, or even a risk of abuse. ${ }^{3}$ Conversely, supporters emphasize the judicial and "apolitical" character of the OTP as essential for the Court's credibility. ${ }^{4}$ An especially delicate question is whether the Prosecutor should exercise discretion based on strictly legal criteria, or include "extralegal" criteria, such as political and practical considerations. ${ }^{5}$ The role of the Prosecutor in selecting situations and cases to investigate and prosecute is certainly pivotal for the functioning of the ICC. Indeed, the Prosecutor has been dubbed the "gatekeeper" of the ICC. ${ }^{6}$ In the best case, a well-calculated and exercised strategy could contribute to achieving the lofty goals of international justice. This begs the question of how the OTP has chosen to exercise its discretion in formal strategies and in practice and if these choices contribute to fulfilling the promise of the permanent global criminal court. In previous

1. Allison M. Danner, Enhancing the Legitimacy and Accountability of Prosecutorial Discretion at the International Criminal Court, 97 Am. J. INT'L L. 510, 513-16 (2003).

2. See examples in James A. Goldston, More Candour about Criteria: The Exercise of Discretion by the Prosecutor of the International Criminal Court, 8 J. INT'L CRIM. Just. 383, 384-86 (2010).

3. William A. Schabas, Victor's Justice: Selecting Situations at the International Criminal Court, 43 J. Marshall L. Rev. 535, 549-50 (2010). See also Alexander K.A. Greenawalt, Justice without Politics? Prosecutorial Discretion and the International Criminal Court, 39 N.Y.U. J. INT'L L. \& Pol. 583, 586-87 (2007); Danner, supra note 1, at 513-14.

4. Danner, supra note 1, at 515; Goldston, supra note 2, at 387; Greenawalt, supra note 3, at $586-87$.

5. Cale Davis, Political Considerations in Prosecutorial Discretion at the International Criminal Court, 15 INT'L CRIM. L. REv. 170 (2015).

6. Héctor Olásolo, The Prosecutor of the ICC before the initiation of investigations: A quasi-judicial or political body?, 3 INT'L CRIM. L. REV. 87, 89 (2003). 
research, this has been identified as a perspective worthy of additional attention. $^{7}$

The purpose of the present study is to identify strategic choices of the OTP in situation and case selection and to analyze them in relation to the ICC's objectives. The overarching question is: how do strategic choices of the OTP correspond to the objectives of the ICC? In order to find an answer, the following sub-questions will be explored: 1) Which objectives of the ICC are relevant for situation and case selection?; 2) what room does the legal framework leave for prosecutorial discretion in situation and case selection?; and, 3) what are some strategic choices that the OTP has made with respect to situation and case selection?

This study will begin with a brief background to the unique role of the ICC Prosecutor when it comes to situation and case selection. Subsequently, relevant objectives of the ICC will be identified, providing a response to the first sub-question. Next, the legal framework for initiating investigations and prosecutions at the ICC will be presented. This will serve to explain the concept of situation and case selection. Furthermore, it will provide a response to the second sub-question, on what room the legal framework leaves for prosecutorial discretion. In the following part of the study, the third sub-question will be addressed by identifying three specific strategic choices: 1) how the choices are reflected in the OTP's policy and strategy documents; 2) how the choices have been applied in specific situations and cases, which may provide a clearer picture of the strategic choices; and 3) the strategic choices in relation to the ICC's objectives. The study will end with a more general discussion on the OTP's role in fulfilling the Court's objectives.

\section{ReseArch Methodology}

Policy may be defined as "a definite course or method of action selected from among alternatives and in light of given conditions to guide and determine present and future decisions." ${ }^{8}$ Similarly, strategy is defined as "a careful plan or method for achieving a particular goal

7. See Margeret M. deGuzman \& William A. Schabas, Initiation of Investigations and Selection of Cases, in International Criminal Procedure: Principles and Rules 131, 133 (Goran Sluiter et al. eds., 2013) (holding that "additional attention should be focused on the manner in which selection decisions contribute to accomplishing and prioritizing the various goals and objectives of international criminal law").

8. Merriam-Webster on-Line Dictionary, Policy, http://www.merriam-webster.com/ dictionary/policy (Jan. 5, 2016). 
usually over a long period of time." ${ }^{\text {A }}$ A distinction can thus be made between the terms, as strategy suggests a more long-term and goaloriented plan. However, for the purposes of this study, the main point is that both policy and strategy are tools to guide the exercise of discretion. Moreover, strategy and policy often entail considerations of a more practical or political nature, bringing them into relevance for legal decision-making. ${ }^{10}$

According to Article 31(1) of the Vienna Convention on the Law of Treaties (VCLT), "a treaty shall be interpreted in the light of its object and purpose." 11 Because the OTP's mandate is based on the Statute and related instruments, it is legally relevant to analyze it in light of the objects and purposes of these instruments. ${ }^{12}$ In a broader sense, when analyzing prosecutorial strategy, it is particularly pertinent to connect it to the underlying objectives of the lawmaker. ${ }^{13}$ Thus, a teleological or "interest-based" method will be used. ${ }^{14}$ A critique against an interestbased method is that objectives can be used in a selective and subjective way to further a certain agenda. ${ }^{15}$ To avoid this, objectives are sought in positive law, or at least where a strong case can be made to that effect. ${ }^{16}$

This study will not attempt to provide a comprehensive analysis of the OTP's strategy and policy on situation and case selection. Instead, it will focus on select strategic choices. The question then becomes how these should be identified. First, an understanding of the legal framework for situation and case selection is necessary to identify the scope of prosecutorial discretion. Thereafter, one method would be to look

9. Merriam-Webster on-Line Dictionary, Strategy, http://www.merriam-webster.com/ dictionary/strategy (Jan. 5, 2016).

10. Rosalyn Higgins, Problems and Process: International Law and How We Use It 4-5 (1995). See also Goldston, supra note 2, at 84; Davis supra, note 5, at 187-89.

11. Vienna Convention on the Law of Treaties, art. 31(1), May 23, 1969, 1155 U.N.T.S. 331.

12. Even though instruments such as the Rules of Procedure and Evidence and the Regulations of the Office of the Prosecutor are not treaties in themselves, but derive their legality from the Rome Statute, the rules of treaty interpretation apply to them. See MARK KLAMberg, EVidence in International Criminal Trials: Confronting Legal Gaps and the Reconstruction OF Disputed Events 20 (2013) (referring to Prosecutor v. Dyilo, ICC-01/04-01/06, Opinion of Judge Steiner, Decision on the Final System of Disclosure and the Establishment of a Timetable, Annex I, II 1 (May 15, 2006)).

13. See Keith Hawkins, The New Oxford Companion to Law 331 (Peter Cane \& Joanne Conaghan eds., 2008). See also deGuzman \& Schabas, supra note 7, at 132 ("Decisions to pursue certain investigations and cases but not others reflect underlying beliefs about the goals and purposes of international criminal law.").

14. See KLAmberg, supra note 12, at 5-11.

15. Id. at 11 ; HigGins, supra note 10 , at $5-6$.

16. See KLAMBerg, supra note 12 , at 51 ; see also infra Section IV. 
at the OTP's strategy in actual practice, i.e., to analyze decisions that relate to situation and case selection. The difficulty with such an approach is identifying the motives behind these choices. The choices of a prosecutor are in practice governed by a wide array of legal, factual, and practical factors. Due to the complex nature of prosecutorial decision-making, it would arguably be difficult to decipher strategies merely from the so far rather limited practice of the OTP.

Another method for identifying strategic choices would be to look at the strategy and policy documents of the OTP. In accordance with Regulation 14 of the OTP, the Office has released a series of strategic plans and policy papers. ${ }^{17}$ These documents are likely the best available sources for finding out strategic motivations behind the choices of the OTP. At the same time, their reliability should not be overestimated. There are clearly inherent difficulties in defining a general prosecutorial strategy, while keeping the necessary flexibility for decisions case-bycase. ${ }^{18}$ Therefore, policy and strategy documents of the OTP should be taken more as guidance than as prescriptions for the OTP's decisionmaking. ${ }^{19}$ Bearing this in mind, the most viable method for identifying strategic choices will arguably be to look at both policy and practice. Using the stated policies and strategies as a starting point and then examining actual decisions can hopefully reconcile the strengths and weaknesses of both types of sources. ${ }^{20}$

As an organ of the ICC, the OTP's mandate is based on the Statute. ${ }^{21}$ According to Article 21 of the Statute, the Court's sources of applicable law are primarily the Statute itself, the Rules of Procedure and Evidence (RPE), and the Elements of Crimes. ${ }^{22}$ In the second place, other treaties, rules, and principles of international law are applicable. Article 21(2) additionally recognizes the Court's own case law as applicable, though not binding for the Court. ${ }^{23}$ Thus, Article 21 largely

17. See infra Section VI.A.

18. For a discussion on the articulation and publication of strategy by the ICC OTP, see Danner, supra note 1, at 541-52; Goldston, supra note 2, at 402-05; Greenawalt, supra note 3, at 652.

19. See Goldston, supra note 2, at 403.

20. For a similar method, see Frederik de Vlaming, Selection of Defendants, in InTERnational Prosecutors 542-71 (Luc Reydams et.al. eds., 2012).

21. Rome Statute of the International Criminal Court arts. 34(c), 42, July 17, 1998, 2187 U.N.T.S. 90 [hereinafter Rome Statute].

22. Id. art. 21.

23. Id. art. 21 (2). See Gilbert Bitti, Article 21 and the Hierarchy of Sources of Law before the ICC, in The Law and Practice of the International Criminal Court 411, 422-25 (Carsten Stahn ed., 2015). 
corresponds to Article 38 of the Statute of the International Court of Justice (ICJ), which recognizes the primary sources of international law as treaties, customs, general principles, and judicial decisions. ${ }^{24}$ Legal literature, also cited in Article 38 of the ICJ Statute, is also relevant to determine and analyze the legal framework within which the OTP operates.

The OTP's functioning is further governed by internally adopted Regulations, pursuant to Rule 9 of the RPE. ${ }^{25}$ As previously explained, for the purposes of this study, the policy and strategy documents of the OTP are also relevant. It should be borne in mind, however, that these documents are not legally binding in a formal sense.

The preparatory works of the Statute, including reports from the various working groups and negotiation sessions that led to its adoption, will be useful to a limited extent. Under Article 32 of the VCLT, preparatory works are but a supplementary means for the interpretation of treaties. ${ }^{26}$ In the particular case of the Statute, available preparatory works are not comprehensive, because part of the negotiations were held informally. ${ }^{27}$ Bearing this in mind, the material can still provide useful background information to Statute provisions. Finally, for comparative purposes, the statutes and other material related to other international tribunals, mainly the International Criminal Tribunal for Rwanda (ICTR) and for the former Yugoslavia (ICTY), will also be useful to a certain extent. ${ }^{28}$

As indicated above, the present study will focus on "sample" strategic choice of the OTP, the selection of which will be motivated later in this study. ${ }^{29}$ Consequently, other aspects of the prosecutorial strategy and policy will be touched upon more briefly. The study will focus solely on the ICC. Although some comparison will be made with other international criminal tribunals, this will serve as illustration rather than as

24. Compare Rome Statute, supra note 21, art. 21 with Statute of the International Court of Justice art 38, June 26, 1945, 59 Stat. 1055, 33 U.N.T.S. 993 [hereinafter ICJ Statute]. See KLAMBERG, supra note 12, at 26-27. Article 38 of the ICJ Statute is widely considered to reflect customary international law. See, e.g., Oppenheim's International Law 24 (Sir Robert Jennings \& Sir Arthur Watts eds., 9th ed. 1992).

25. See Bitti, supra note 23, at 421-22 where these are referred to as "supplementary legal texts."

26. Vienna Convention on the Law of Treaties, supra note 11, art. 32.

27. See Anotonio Cassese, The Statute of the International Criminal Court: Some Preliminary Reflections, 10 Eur. J. INT'L L. 144, 145 (1999).

28. On the relevance of the jurisprudence of the ad hoc tribunals for the ICC, see Bitti, supra note 23, 427-29.

29. See infra Section VI. 
comprehensive comparative analysis. Similarly, no significant comparisons to national legal systems will be made.

\section{Background: A Unique Prosecutor}

\section{A. Prosecutorial Discretion in General}

In domestic legal systems, prosecutors enjoy varying degrees of discretion in choosing whether or not to pursue cases, which persons to prosecute, and on what charges. Legal systems of the common law tradition generally grant prosecutors a higher degree of discretion than those of the civil law tradition. ${ }^{30}$ Many common law prosecutors may, for instance, decline to prosecute based on an assessment that it would not serve the public interest. The discretion of civil law prosecutors may be curtailed either by legal requirements or by judicial oversight. Some systems apply a principle of mandatory prosecution, subject only to narrow legal exceptions, such as de minimis limits. ${ }^{31}$ Other systems grant prosecutors more discretion, but make it subject to oversight by judges.

When it comes to prosecutorial discretion, there is a key difference between domestic legal systems and international criminal justice. International prosecutors are generally concerned only with crimes of the gravest kind, such as war crimes, crimes against humanity, and genocide. ${ }^{32}$ In the investigation and prosecution of such serious and violent crimes, domestic legal systems generally aspire to universality. ${ }^{33}$ This means that, though some narrow exceptions may apply, the general assumption is that a domestic prosecutor will not decline to prosecute such a crime to the full extent to its powers. International prosecutors, however, are more constrained in terms of mandate and capacity, and must exercise some selectivity with respect to the crimes under their jurisdiction. ${ }^{34}$

30. Greenawalt, supra note 3, at 599-60; Danner, supra note 1, at 512-13; deGuzman \& Schabas, supra note 7, at 157-60.

31. deGuzman \& Schabas, supra note 7, 160-62.

32. Luc Reydams \& Jed Odermatt, Mandates, in International Prosecutors 81, 82 (Luc Reydams et al. eds., 2012). See, e.g., Rome Statute, supra note 21, art. 5.

33. See Louise Arbour, The Need for an Independent and Effective Prosecutor in the Permanent International Criminal Court, in 17 Windsor Y.B. ACCEss Just. 207, 213 (1999); William A. Schabas, Selecting Situations and Cases, in The LaW and Practice of the International Criminal Court 365 (Carsten Stahn ed., 2015); Greenawalt, supra note 3, at 610.

34. Arbour, supra note 33, at 213. 
The prosecutors of the post-World War II international military tribunals in Nuremberg (IMT) and the Far East in Tokyo (IMTFE) enjoyed a limited degree of discretion and independence. ${ }^{35}$ As representatives of the Allied governments which had set up the tribunals, they were not completely shielded from political influence. ${ }^{36}$ Furthermore, their mandate was limited to prosecuting "major war criminals" of the Axis powers. ${ }^{37}$ When the Security Council (SC) established the ad hoc international criminal tribunals for the former Yugoslavia and Rwanda, it stipulated that the prosecutors would be independent, and that they should not seek or receive instructions from governments or other outside sources. ${ }^{38}$ The mandates of these tribunals, like those of the IMT and IMTFE, are limited to the contexts of particular conflicts, hence the term ad hoc tribunals. ${ }^{39}$ However, within these parameters, the prosecutors exercise considerable discretion in deciding who to prosecute and on what charges. In this sense, they act as common law prosecutors, but with respect to very serious crimes.

\section{B. The Prosecutor of the ICC}

The ICC Prosecutor is independent like the prosecutors of the ad hoc tribunals. This is stipulated in Article 42(1) of the Statute, and it includes not seeking nor acting on instructions from outside actors. ${ }^{40}$ What makes the ICC Prosecutor unique is primarily the permanent and global nature of the Court. The Court's jurisdiction is limited in subject-matter to "the most serious crimes of concern to the interna-

35. Luc Côté, Independence and Impartiality, in International Prosecutors 319, 372-73 (Reydams et al. eds., 2012).

36. Id

37. See Charter of the International Military Tribunal, art. 1, Aug. 8, 1945, 59 Stat. 1546, 82 U.N.T.S. 284, [hereinafter IMT Charter]; Charter of the International Military Tribunal for the Far East art. 1, Jan. 19, 1946, T.I.A.S. No. 1589 [hereinafter IMTFE Charter].

38. International Tribunal for the Prosecution of Persons Responsible for Serious Violations of International Humanitarian Law Committed in the Territory of the Former Yugoslavia since 1991 art. 16(2), S.C. Res. 827, U.N Doc. S/Res/827 (May 25, 1993) [hereinafter ICTY Statute]; Article 15(2), Statute of the International Criminal Tribunal for Rwanda, S.C. Res. 955, annex, art 4, U.N. Doc. S/RES/955 (Nov. 8, 1994) [hereinafter ICTR Statute].

39. For the sake of simplicity, the prosecutors of "internationalized" or "hybrid" criminal tribunals such as the Special Court for Sierra Leone, the East-Timor Tribunal, the Extraordinary Chambers in the Courts of Cambodia, the Court of Bosnia and Herzegovina and the Special Tribunal for Lebanon are left out here.

40. Rome Statute, supra note 21, art. 42(1). See also Regulations of the Office of the Prosecutor, reg. 12, ICC-BD/05-01-09 (Apr. 23, 2009) [hereinafter OTP Regulation]. 
tional community," ${ }^{41}$ defined in Article 5 of the Statute as war crimes, crimes against humanity, genocide, and aggression. ${ }^{42}$ The fact that the Court is treaty-based means some additional limits on its temporal ${ }^{43}$ and geographical jurisdiction. ${ }^{44}$ However, within these limits, the Court's mandate is general rather than specific. ${ }^{45}$ Unlike his or her predecessors, the precise parameters of the ICC Prosecutor's investigations are not predetermined in underlying legislation. ${ }^{46}$ Instead, he or she needs to engage in a process of identifying general contexts, known as "situations," within which to conduct investigations. Section V of this study will thoroughly explain this process, as well as the distinction between the terms "situation" and "case." In conclusion, the ICC Prosecutor exercises an unprecedentedly high degree of selectivity with regard to some of the most serious crimes.

\section{The Objectives of the ICC}

As a first step in the analysis of the OTP's strategic choices, the relevant objectives of the ICC must be identified. The assumption behind the formation of the ICC is that, like all legal institutions, the ICC was established to meet certain social needs, which are described in this article as objectives which may be both conflicting and mutually enforcing. ${ }^{47}$ The aim of this section is to identify objectives that are arguably rooted in positive law, and thus relevant to an interest-based analysis of the OTP's strategic choices. ${ }^{48}$ An inventory of potential objectives includes ending impunity, preventing crimes, improving respect for international law, restoring international peace and security, creating a historical record, providing redress for victims and other interrelated objectives elaborated upon in the following sections.

41. Rome Statute, supra note 21, pmbl.

42. Id. art. 5 .

43. Id. art. 11.

44. Id. art. 12. See also infra Section V.B.

45. See Reydams \& Odermatt, supra note 32, at 108.

46. See IMT Charter, supra note 37, art. 1; IMTFE Charter, supra note 37, art. 1; ICTY Statute, supra note 38, art. 1; ICTR Statute, supra note 38, art. 1. See also Olásolo, supra note 6, at 91-92.

47. See Roscoe Pound, Philosophical Theory and International Law, BibliotheCA VISSERIANA dissertationum Jus internationale illustrantium 71, 89 (1923); Martti Koskenniemi, From Apology to Utopia: The Structure of International Legal Argument 24 (2005); KLAmBerG, supra note 12 , at $5,7,11,48-51$.

48. See infra Section II. 


\section{A. Ending Impunity}

The preamble is a natural starting point for identifying the objects and purpose of a treaty. ${ }^{49}$ The ICC Appeals Chamber has stated that the aims of the Statute "may be gathered from its preamble and general tenor of the treaty." 50 The Statute Preamble contains several principal statements from which objectives can be derived. As the Appeals Chamber has stated, perhaps the most obvious objective is the punishment of core international crimes. ${ }^{51}$ This purpose can also be derived from the Statute as a whole, providing a substantive and procedural framework for the prosecution of such crimes.

Paragraph 4 of the Preamble states that: "the most serious crimes of concern to the international community as a whole must not go unpunished and that their effective prosecution must be ensured by taking measures at the national level and by enhancing international cooperation." ${ }^{2}$ The "most serious crimes" refers to the crimes under Court's subject-matter jurisdiction under Article 5 of the Statute, also commonly referred to as "core," "grave," or "atrocity" crimes. ${ }^{53}$ The reference to measures at the national level is linked to the principle, more clearly expressed in paragraph 10 of the Preamble, that the ICC shall be complementary to national jurisdictions. ${ }^{54}$

In a similar vein, paragraph 5 of the Preamble reads: "Determined to put an end to impunity for the perpetrators of these crimes and thus to contribute to the prevention of such crimes." ${ }^{\text {55 }}$ Being framed as a purpose of ending impunity, prevention is sometimes viewed as the supreme objective of the ICC. ${ }^{56}$ However, ending impunity and prevent-

49. See Mark E. Villiger, Commentary on the 1969 Vienna Convention on the LaW of TrEATIES 428 (2009).

50. Situation in the Democratic Republic of the Congo, ICC-01/04-168, Judgment on the Prosecutor's Application for Extraordinary Review of Pre-Trial Chamber I's 31 March 2006 Decision Denying Leave to Appeal, II 33 (ICC App. Chamber July 13, 2006).

51. Id. I 37.

52. Rome Statute, supra note 21, pmbl.

53. William A. Schabas, The International Criminal Court: A Commentary on the Rome STATUTE, $2^{\mathrm{ND}}$ Edition, 40-42 (2016). For a critical discussion on the concept of international crimes, see Roger O’Keefe, International Criminal Law 63 (2015).

54. See more on the principle of complementarity infra Section V.C.3.a.

55. Rome Statute, supra note 21, pmbl.

56. Jens David Ohlin, Goals of International Criminal Justice and International Criminal Procedure, in International Criminal Procedure: Principles and Rules 55, 59 (Goran Sluiter et al. eds., 2013); Gustavo Gallón, The International Criminal Court and the Challenge of Deterrence, in international Crimes, Peace, and Human Rights: The Role of the International Criminal CourT 93, 93-94 (Dinah Shelton ed., 2000). 
ing crimes can also be seen as distinct, albeit closely linked, objectives. ${ }^{57}$ While ending impunity primarily relates to the punishment of crimes committed, prevention is forward-looking. ${ }^{58}$ Moreover, ending impunity can have purposes besides prevention, such as retribution, rehabilitation, stigmatization, and redress. ${ }^{59}$ These purposes may be conflicting, mutually reinforcing, complementary, or overlapping. In different criminal legal systems, they are emphasized and balanced against each other in different ways. Without delving deeper into these issues, it appears that the drafters of the Statute have placed some emphasis on the preventative purpose.$^{60}$ However, the statement that serious crimes must not go unpunished also seems to suggest a more retributive or restorative concept of justice.

The goal of ending impunity is lofty and likely impossible to fully achieve. In a court-wide ICC strategic plan, the objective has been framed in terms of "fighting" impunity rather than ending it. ${ }^{61}$ Through the principle of complementarity, it has been recognized that the objective cannot be attained by the ICC alone, but is a collective global endeavor. In an early policy paper, the OTP stated that the absence of trials before the ICC could even be a success if it was due to the proper functioning of national justice systems. ${ }^{62}$ But if states do not adequately deal with serious international crimes, the ICC is supposed to step in. Therefore, in terms of contributing to the objective of ending impunity, the ICC's performance could arguably be assessed by factors such as efficiency, but also the quality and credibility of proceedings. ${ }^{63}$

\section{B. Preventing Crimes}

The goal of preventing future crimes was less prominent for the ad hoc criminal tribunals because they were created in the aftermath of

57. Ohlin, supra note 56; Gallón, supra note 56.

58. Ohlin, supra note 56; Gallón, supra note 56.

59. Ohlin, supra note 56, at 59; Gallón, supra note 56, at 93-94.

60. Ohlin, supra note 56; Gallón, supra note 56, at 93-94.

61. Int'l Criminal Court, International Criminal Court Strategic Plan 2013-2017, 2 (July 24, 2015), https://www.icc-cpi.int/iccdocs/registry/Strategic_Plan_2013-2017__update_Jul_2015. pdf.

62. Office of the Prosecutor, Int'l Criminal Court, Paper on some policy issues before the Office of the Prosecutor 4 (Sept. 2003) [hereinafter Paper on SOME POlicy issues before the OfFice of the Prosecutor].

63. See KLAMBERG, supra note 12, at 52. 
large-scale crimes. ${ }^{64}$ As a permanent and global court, the ICC could potentially play a deterrent role in a similar way to national courts. Deterrence can be specific, such as impacting the person prosecuted, or general, such as impacting the public at large. For the ICC, the ambition seems to be general deterrence on a global scale, not only discouraging prospective perpetrators in the situations under examination by the Court but also in vastly different situations. ${ }^{65}$

The deterrent effect of criminal prosecution has been questioned both in the domestic and international context. ${ }^{66}$ Assuming that such an effect depends on the likelihood of prosecution, it is surely more difficult for an international tribunal to achieve than it is for functioning national legal systems. ${ }^{67}$ Moreover, some argue that perpetrators of core international crimes are especially unlikely to be deterred by the threat of prosecution. ${ }^{68}$ These crimes often have strong ideological, economic, or political motives, particularly when committed by highranking political or military leaders ${ }^{69}$ For such actors, the threat of international prosecution may even pale in comparison to other risks facing them, such as military defeat or summary execution. ${ }^{70}$ Furthermore, powerful persons may be able to shield themselves from prosecution using various tactics.

Leaving aside the question of whether or not the ICC can be successful in preventing crimes, the objective can likely be seen as a lofty aspiration similar to ending impunity. Assuming that a preventative effect is not totally unrealistic, it is therefore relevant to consider ways for the Court, including the OTP, to maximize it. The threat of prosecution may perhaps be enhanced by, for example, achieving a high number of convictions, or by targeting perpetrators in a strategic manner.

64. This is somewhat of a simplification, because the ad hoc tribunals also aimed to promote lasting peace, thereby preventing future crimes. See Greenawalt, supra note 3, at 604 .

65. See Greenawalt, supra note 3, at 605; Office of the Prosecutor, Int'l Criminal Court, Report on Prosecutorial Strategy 6 (Sept. 14, 2006) [hereinafter 2006 Report on Prosecutorial Strategy].

66. Ohlin, supra note 56 , at 58-59.

67. Mirjan R. Damaška, What is the Point of Int'l Criminal Justice?, 83 Chi.-Kent L. Rev. 329, 344-45 (2008). See also Greenawalt, supra note 3, at 610.

68. Damaška, supra note 67, at 344; Gallón, supra note 56, at 97-98; Greenawalt, supra note 3, at $605-07$.

69. Damaška, supra note 67, at 344; Gallón, supra note 56, at 97-98; Greenawalt, supra note 3, at 605-07.

70. See Greenawalt, supra note 3, at 607 . 


\section{Improving Respect for International Law}

Paragraph 11 of the Statute Preamble reads: "Resolved to guarantee lasting respect for and the enforcement of international justice."71 This might be indicative of a more normative goal of international criminal justice-namely, to strengthen respect for the norms of international law and, in particular, human rights and humanitarian law. ${ }^{72}$ The scholar Mirjan Damaška-known for his works in the fields of comparative criminal justice and international criminal law- has suggested that such a pedagogical goal should be central to the mission of international criminal justice. ${ }^{73}$ Unlike deterrence, he argues, a pedagogical effect could be attained despite a low probability of punishment. ${ }^{74}$ Court proceedings can serve as examples whereby crimes are exposed, denounced and stigmatized. ${ }^{75}$ This could in turn contribute to a stronger "sense of accountability" within the international community. ${ }^{76}$ To put it differently, the goal is to end a "culture of impunity"77 by demonstrating non-acceptance on behalf of the international community.

The pedagogical and preventative objectives are, of course, closely linked. It could be argued that the promotion a "sense of accountability" ultimately aims to achieve prevention. ${ }^{78}$ On the other hand, perhaps respect for international human rights and humanitarian law could be strengthened in a wider sense, beyond the prohibition of core international crimes. A system of international justice could perhaps feed into a wider narrative of fostering political and public support for the rule of law. Conversely, it is does not seem unlikely that a "culture of impunity" contributes to a weaker respect for international legal norms in general. As Damaška notes, the pedagogical effect requires that the Court is perceived as legitimate. ${ }^{79}$ Otherwise, it cannot credibly act as a

71. Rome Statute, supra note 21, pmbl.

72. See Ohlin, supra note 56, at 58; Dominic McGoldrick, The Legal and Political Significance of a Permanent International Criminal Court, in The Permanent International Court: Legal and Policy Issues 453, 459-60 (Dominic McGoldrick et al. eds. 2004).

73. Damaška, supra note 67 , at $345-47$ (referring to the goal as didactic or sociopedagogical).

74. Id.

75. Id.

76. $I d$.

77. See McGoldrick, supra note 72 , at 459 .

78. Id.

79. Damaška, supra note 67 , at 345 . 
legal and moral authority. Legitimacy, in its turn, will likely depend on such factors as the quality and fairness of decisions and procedures. ${ }^{80}$

\section{Restoring International Peace and Security}

An objective that is often associated with international criminal justice is the contribution to international peace and security. This objective was, in a sense, the very legal basis for the establishment of the ICC's predecessors, the U.N. ad hoc tribunals. The tribunals were established by the SC, using its binding powers under Article 41, Chapter VII of the U.N. Charter. These powers are derived from the $\mathrm{SC}^{\prime}$ 's role as the U.N. body primarily charged with maintaining international peace and security under Article 24 of the U.N. Charter. ${ }^{81}$ Establishing tribunals is a non-military measure to that end, like economic sanctions or blockades. ${ }^{82}$ Thus, the establishment of the $a d$ $h o c$ tribunals was premised on the notion that justice on the individual criminal level can contribute to peace and reconciliation on a national and international level. ${ }^{83}$ The purpose of promoting peace and reconciliation has later been emphasized in the case law of the ICTY, most clearly by the Tribunal's Appeals Chamber in the Tadic case. ${ }^{84}$

Unlike the ad hoc tribunals, the ICC does not derive its mandate from a SC resolution, but from the Statute. However, there are strong connections between the Court and the U.N., and in particular the SC. ${ }^{85}$ Most importantly, the SC has the power to extend the Court's jurisdiction by referring situations under Chapter VII of the U.N. Charter. ${ }^{86}$ Because restoring international peace and security is the objective of such referrals, it can convincingly be argued that the

80. Id.; McGoldrick, supra note 72, at 460 .

81. U.N. Charter art. 24.

82. Nico Krisch, Article 41, Actions with Respect to Threats, Breaches of the Peace and Acts of Aggression, in 2 The Charter of the United Nations: A Commentary 1305, 1319-22 (Bruno Simma et al. eds., 3d ed. 2012).

83. Ohlin, supra note 56 , at 56 .

84. Prosecutor v. Tadic, Case No. IT-94-1, Decision on the Defense Motion for Interlocutory Appeal on Jurisdiction, II II 32-48 (Int'l Crim. Trib. For the Former Yugoslavia App. Chamber Oct. $2,1995)$.

85. See Rome Statute, supra note 21, arts. 2, 115(b) (discussing the relationship of the Court with the U.N. and the funds of the Court); Negotiated Relationship Agreement between the International Criminal Court and the United Nations, ICC-ASP/3/Res.1, Oct. 2004.

86. See infra Section V.B.2. 
following investigations and prosecutions also have this objective. ${ }^{87}$ Furthermore, if the underlying rationale that criminal prosecutions can contribute to peace is accepted, this should logically apply to all ICC prosecutions in situations of conflict, not just in the situations referred by the SC. ${ }^{88}$

Certain phrases in the Statute Preamble also seem to support the idea that restoring peace and security is an objective of the ICC. First, Paragraph 3 recognizes that grave crimes "threaten the peace, security and well-being of the world." 89 This reflects a similar view on the correlation of individual criminal responsibility and the broader interest of peace that was underlying the creation of the $a d$ hoc tribunals. ${ }^{90}$ Second, Paragraph 4 reaffirms the purposes and principles of the U.N. Charter. ${ }^{91}$ Under Article 1 of the Charter, the purposes include the maintenance of international peace and security. ${ }^{92}$ The principles under Article 2 include the settlement of international disputes by peaceful means, as well as the prohibition of the use of force, which is especially emphasized in the Statute Preamble. ${ }^{93}$

However, the idea that criminal prosecutions contribute to peace is not uncontroversial. Some question if criminal prosecutions are necessarily the right way of dealing with conflict-related crimes. ${ }^{94}$ It has instead been proposed that "alternative transitional justice mechanisms," such as truth commissions or even amnesty programs, may be more appropriate for the promotion of peace and reconciliation. ${ }^{95}$ This is premised on the notion that justice and peace may be conflicting interests in certain contexts. Leaving this discussion aside for now,

87. William A. Schabas and Guilia Pecorella, Article 13: Exercise of Jurisdiction, in COMMENTARY ON THE ROME STATUTE OF THE INTERNATIONAL CRIMINAL COURT 690, 701 (Otto Triffterer \& Kai Ambos eds., 2016).

88. See infra Section V.B. for more on the so-called trigger mechanisms.

89. Rome Statute, supra note 21, pmbl.

90. See Schabas, The International Criminal Court, supra note 53, at 43-44.

91. Rome Statute, supra note 21, pmbl.

92. U.N. Charter art. 1, I 1.

93. U.N. Charter art. 2, III 3-4.

94. Greenawalt, supra note 3 , at $614-20$.

95. Id. See also Thabo Mbeki \& Mahmood Mamdani, Courts Can't End Civil Wars, N.Y. Times (Feb. 5, 2014), http://www.nytimes.com/2014/02/06/opinion/courts-cant-end-civil-wars.html?_ $\mathrm{r}=0$; Rianne Lestschert \& Marc Groenhuijsen, Not Everyone Thinks the ICC in Syria is a Good Idea, JUST. IN CONFLICT (June 12, 2014), http://justiceinconflict.org/2014/06/12/not-everyone-thinksthe-icc-in-syria-is-a-good-idea/; Leslie Vinjamuri, The ICC and the Politics of Conflict, in THE LAW AND Practice Of THE INTERNATIONAL Criminal Court 12-29 (Carsten Stahn ed., 2015). 
it appears that a compelling case can be made for including peace and security among the objectives of the ICC.

\section{E. Creating a Historical Record}

Another objective traditionally associated with international criminal justice is the creation of historical records of conflicts. ${ }^{96}$ This is a task more clearly vested in other institutions, such as truth and reconciliation commissions. ${ }^{97}$ However, the evidence collected for court proceedings might also contribute to uncovering the truth and preserving the memory of the broader context of crimes. ${ }^{98}$ This is especially relevant for international core crimes, because they are often large-scale with considerable political and societal implications. ${ }^{99}$ Memory and truth are generally held to contribute to post-conflict reconciliation, but creating historical records can also be seen as an end in itself. ${ }^{100}$

Under Article 54(1) (a) of the Statute, the Prosecutor has a "truthseeking" role while conducting investigations. ${ }^{101}$ The OTP shall extend the investigation to all relevant facts, and investigate incriminating and exonerating circumstances equally. ${ }^{102}$ The "truth" to be established primarily relates to the specific conduct of the accused. ${ }^{103}$ However, regardless of the primary purpose, the evidence produced by broad and objective investigations can, in practice, also serve the purposes of memorialization. Correspondingly, placing emphasis on a historical objective might create a tendency to stretch investigations as broadly as possible. For this reason, the objective is criticized by Damaška. ${ }^{104} \mathrm{He}$ points out that the historic truth uncovered by legal proceedings will be governed by legal relevance, not historical relevance. ${ }^{105}$ Therefore, he holds that the best international criminal courts can achieve are fragmentary historical accounts. ${ }^{106}$ These accounts can then be built upon by more dedicated "truth-seekers," such as historians or truth commissions.

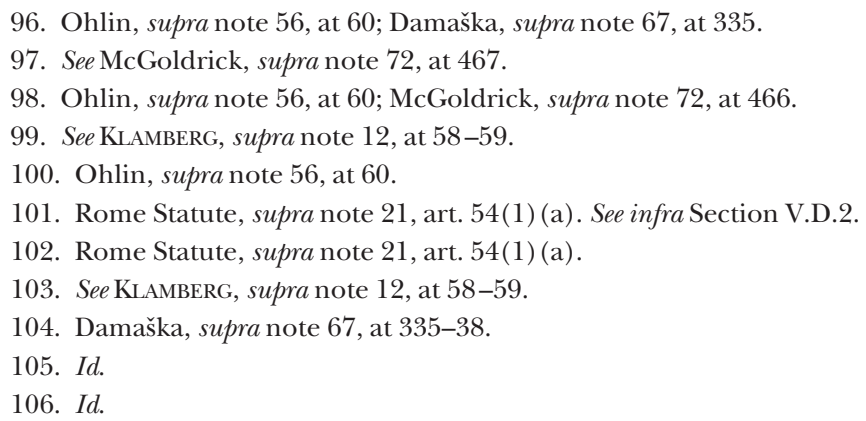


Damaška's conclusion is not to disregard the historical objective completely, but to suggest that it should have a modest place among the objectives of international criminal justice. It could be argued that even a modest contribution to the memorialization of conflict is worth some effort. Moreover, perhaps facts included in judgments and decisions, bearing the "hallmark" of legal evidence, are not as easily denied and distorted as facts conveyed to the public in other forms. As expressed by former ICTY and ICTR Prosecutor Louise Arbour, "[a] criminal court provides an official, final, binding conclusion about historical facts, upon which may rest the legitimate deprivation of a person's liberty for life." ${ }^{107}$ Such a function of the Court's judgment would, of course, require that they are both communicated and perceived as reasonably fair and credible.

\section{F. Providing Redress for Victims}

Victims' interests have been described as a clear theme running through the Statute. ${ }^{108}$ Paragraph 2 of the Preamble recognizes the suffering of victims, stating that "during this century millions of children, women and men have been victims of unimaginable atrocities that deeply shock the conscience of humanity." 109 The Statute and the RPE provide for victim participation at various stages of proceedings ${ }^{110}$ and a unique reparations regime. ${ }^{111}$ The interests of victims are also included among the parameters for selecting situations and cases. ${ }^{112}$ The Court Registry contains a Victims and Witnesses Unit, responsible for security arrangements, information, and other forms of assistance to victims appearing before the Court. ${ }^{113}$ In addition, the ICC Trust Fund for Victims has a broad mandate to deliver different forms of reparations to victims of ICC crimes and their families. ${ }^{114}$ In sum, an objective of providing redress to victims can arguably be gathered from

107. Arbour, supra note 33, at 216.

108. McGoldrick, supra note 72, at 464. See also Schabas, The International Criminal Court, supra note 53, at 42-43.

109. Rome Statute, supra note 21, pmbl.

110. Id. art. 68; Int'l Criminal Court, Rules of Procedure and Evidence, rules 89-93, IT/32/Rev.50 (2015) [hereinafter RPE].

111. Rome Statute, supra note 21, art. 75; RPE, supra note 110, rules 94-99.

112. Rome Statute, supra note 21, arts. 53(1) (c), (2) (c).

113. Rome Statute, supra note 21, art. 43(6); RPE, supra note 110 , rules 16-19.

114. Rome Statute, supra note 21, art. 79; RPE, supra note 110, rule 98; INT'L CRIMINAL CourT, Establishment of a fund for the benefit of crimes within the jurisdiction of the Court, and of the families of such victims, ICC-ASP/1/Res.6 (Sept. 9, 2002). 
the Preamble and general tenor of the Statute. ${ }^{115}$

It can be argued that redress for victims is one of the main purposes of ending impunity. ${ }^{116}$ Alternatively, the community of victims could be seen as one of the interested parties to proceedings at the ICC alongside accused persons, states, and the international community, whose interests must all be balanced against each other. ${ }^{117}$ Therefore, placing too much emphasis on the interests of victims may in some cases be problematic. For example, as the interests of victims will generally weigh in favor of convictions, this must not come at the expense of the right of the accused to a fair trial. ${ }^{118}$

\section{G. Broad and Interrelated Objectives}

This section does not aspire to present an exhaustive or indisputable list of the ICC's objectives. ${ }^{119}$ Instead, a few objectives that appear rooted in positive law have been presented. Mindful that objectives can operate on different levels, broad objectives are used that apply to the ICC as a whole. ${ }^{120}$ An alternative would have been more specific strategic goals of the ICC, or particularly of the OTP. ${ }^{121}$ Such objectives perhaps relate more closely to the strategic choices of the OTP. However, they are more temporary and susceptible to change. Also, they are not as legally authoritative as the objectives that can be derived from the Preamble and Statute as a whole. Moreover, the OTP's role in selecting situations and cases is arguably pivotal for the functioning of the Court, and consequently, for the reaching of its "highest" objectives.

Though the Statute Preamble is a useful starting point for finding objectives, its provisions are brief and somewhat vague. Because the objectives have rarely been interpreted by the Court, the writings of international criminal law scholars and practitioners, such as those

115. See also Reydams \& Odermatt, supra note 32, at 109.

116. Gallón, supra note 56, at 93 .

117. See Madeline Morris, Complementarity and its Discontents: States, Victims and the International Criminal Court, in International Crimes, Peace and Human Rights: The Role of the InTERnAtional Criminal Court 177-201 (Dinah Shelton, ed.2000) [hereinafter Morris].

118. Damaška, supra note 67, at 333-34; KLAMBERG, supra note 12, at 61. See also Rome Statute, supra note 21 , art. $68(3)$.

119. See Klamberg, supra note 12, at 50.

120. See deGuzman \& Schabas, supra note 7, at 163.

121. See Office of the Prosecutor, Int'l Criminal Court, Prosecutorial Strategy 200920122 (Feb. 2010) [hereinafter Prosecutorial Strategy 2009-2012]; Office of the Prosecutor, Int'l Criminal Court, Strategic Plan 2012-2015 17 (Oct. 2013) [hereinafter OTP Strategic Plan 2012-2015]; Office of the Prosecutor, Int'l Criminal Court, Strategic Plan 2016-2018 17-18 (Nov. 2016) [hereinafter OTP Strategic Plan 2016-2018]. See further infra Section VI. 
cited throughout this section, may be relied upon for more elaborate interpretations. ${ }^{122}$ Though there seems to be agreement in the examined literature on the broad strokes of objectives, it is clear that they can be framed and categorized in several different ways. ${ }^{123}$ Moreover, the objectives are often closely linked or even overlapping. ${ }^{124}$ Different hierarchies and ways of subsuming objectives under each other might be suggested. ${ }^{125}$ However, for present purposes, it is not necessary to establish a clear ranking order between the objectives. In fact, it is arguably not even necessary to make completely watertight distinctions between them. Instead, it is understood and accepted that the objectives will sometimes overlap, complement each other, and come into conflict. The question that is interesting here is in what way the strategic choices of the OTP, either expressly or tacitly, reflect considerations, prioritizations, and interpretations of the identified objectives. ${ }^{126}$

\section{The Legal Framework for Situation and Case Selection}

The following sections will present the legal framework for situation and case selection, beginning with an explanation of the terms "situation" and "case." The aim is to respond to sub-question two posed in this Article's Introduction: what room does the legal framework leave for prosecutorial discretion in situation and case selection? Consequently, the procedural steps that entail prosecutorial decision-making will be highlighted, while other procedural steps will be explained more briefly for the sake of completeness.

\section{A. Situations and Cases: What is the Difference?}

The term "situation" has been interpreted by the Pre-Trial Chamber (PTC) I as being "generally defined in terms of temporal, territorial and, in some cases, personal parameters." ${ }^{27}$ Thus, simply put, a

122. See Ohlin, supra note 56 , at 55.

123. Compare, e.g., id. at 55-60 with Damaška, supra note 67, at 340-47.

124. Ohlin, supra note 56 , at 56.

125. See KlamberG, supra note 12, at 50; Damaška, supra note 67, at 339-40. For example, it could be argued that prevention and redress for victims should be subsumed under ending impunity. Alternatively, it could be argued that ending impunity, improving respect for international law and creating a historical record should be subsumed under prevention.

126. See deGuzman \& Schabas, supra note 7, at 163.

127. Situation in the Democratic Republic of the Congo, ICC-01/01-101-tEN-Corr, Decision on Applications for Participation in the Proceedings of VPRS-1, VPRS-2, VPRS-3, VPRS-4, VPRS-5 and VPRS-6, II 65 (PTC I Jan. 17 2006) [hereinafter DRC Decision on Applications for Participation in the Proceedings of VRPS-1-6]. 
situation is a more general context within which cases may be identified during the course of investigations. ${ }^{128}$ A situation may cover the entire territory of a specific state, such as the Democratic Republic of the Congo (DRC) or Kenya, or a more limited region or area within a state, such as Darfur, Sudan or "in and around South Ossetia, Georgia."129 Article 11 of the Statute limits all situations to the time after the Statute entered into force. Additional temporal limits may also be imposed, such as in the Situation in Georgia. ${ }^{130}$ Because the Court's jurisdiction can be either territorially or personally based, situations can also be limited in terms of the nationality of defendants, as in the Situation in Iraq. ${ }^{131}$

The same PTC I decision that defined situations also defined cases. It stated that "cases, comprising specific incidents during which one or more crimes within the jurisdiction of the Court seem to have been committed by one or more identified suspects, entail proceedings that take place after the issuance of a warrant of arrest or a summons to appear." ${ }^{132}$ Accordingly, what separates cases from situations appears to be that the former a) concern specific incidents, persons and conduct, and b) formally arise at a later stage of proceedings, namely when the PTC issues a warrant or summons. ${ }^{133}$

The distinction between situations and cases is not as clear in practice as in theory. In fact, a situation necessarily consists of a number of potential cases. ${ }^{134}$ While investigating situations, the OTP will therefore need to work on one or a number of case hypotheses. As the investigation evolves, these hypotheses may eventually become the object of arrest warrants or summonses to appear, thereby turning into

128. Rod Rastan, "What is a 'Case' for the Purpose of the Rome Statute?," 19 Crim. L.F., 435, 435 (2008).

129. See Situation in Georgia, ICC-01/15, Decision on the Prosecutor's request for authorization of an investigation, If 64 (PTC I Jan. 27, 2016) [hereinafter Georgia authorization decision].

130. Id. The situation concerns the period between July 1 and October 10, 2008.

131. The situation only covers crimes allegedly committed by nationals of the United Kingdom in Iraq. Because Iraq has neither ratified the Statute nor accepted the ICC's jurisdiction, the Court cannot exercise territorial jurisdiction in accordance with Article 12(2) (a). However, because the United Kingdom is a state party to the Statute, the Court may exercise jurisdiction over crimes allegedly committed by its nationals in Iraq accordance with Article 12(2) (b).

132. DRC Decision on Applications for Participation in the Proceedings of VRPS-1-6, supra note 124, I 65 .

133. The issue of when a case arises is not entirely unambiguous, because certain provisions of the Statute refer to the existence of a "case" at earlier stages of proceedings. For a discussion of these issues, in the context of the application of the principle of complementarity, see Rastan, supra note 128 , at $440-43$.

134. See Schabas, Selecting Situations and Cases, supra note 33, at 367. 
cases in the eyes of the Court. ${ }^{135}$ Therefore, it is fair to say that a case arises at an earlier stage in the eyes of the OTP.

\section{B. Trigger Mechanisms}

There are three ways in which the investigation of a situation by the OTP can be initiated. These so-called "trigger mechanisms" are listed in Article 13 of the Statute. ${ }^{136}$ First, a situation can be referred to the Prosecutor by a state party to the Statute. ${ }^{137}$ Second, it can be referred by the SC acting under Chapter VII of the U.N. Charter. ${ }^{138}$ Third, the OTP may initiate investigations proprio motu, on its own accord, based on information from other sources. ${ }^{139}$

\section{State Referrals}

To date, the OTP has received five referrals from countries: Uganda, the DRC, the Central African Republic (CAR), Mali, and the Union of Comoros. The first four were so-called "self-referrals" and concerned situations on the territories of the referring countries. All four have led to the opening of investigations. ${ }^{140}$ The referral from Comoros concerned incidents on registered vessels of Comoros, Greece, and Cambodia, and did not lead to the opening of an investigation. ${ }^{141}$

\section{Security Council Referrals}

Security Council referrals require a resolution under Chapter VII of the U.N. Charter in the wake of identifying a threat to international

135. See OTP Strategic Plan 2016-2018, supra note 121, at 15.

136. See, e.g., Schabas, The International Criminal Court, supra note 53, at 367. Also known as notitia criminis. See, e.g., Giulano Turone, Powers and Duties of the Prosecutor, in 2 Antonio Cassese, The Rome Statute of the International Criminal Court: A Commentary 1137, 1143-46 (2002).

137. Rome Statute, supra note 21, arts. 13(a), 14.

138. Id. art. 13(b).

139. Id. arts.13(c), 15(1). Although art. 15 refers to both cases and situations, it is clear from case law that proprio motu investigations, like state and SC referrals, concern situations. See Situation in the Republic of Kenya, ICC-01/09-19-Corr, Decision Pursuant to Art 15 of the Rome Statute on the Authorization of an Investigation into the Situation in the Republic of Kenya, III 40-48, (PTC II Mar. 31, 2010) [hereinafter Kenya authorization decision].

140. Schabas, The International Criminal Court, supra note 53, at 387-390. For a discussion on the phenomenon of self-referrals, see Harmen Van Der Wilt, Self-Referrals as an Indication of the Inability of States to Cope with Non-State Actors, in The Law and Practice of the InTernational Criminal Court 210 (Carsten Stahn ed. 2015).

141. See infra Section VII.B.2 for more. 
peace and security. ${ }^{142}$ This possible action by the SC is meant to replace the need for ad hoc tribunals. ${ }^{143}$ As opposed to state referrals and proprio motu investigations, SC referrals are exempt from a jurisdictional requirement in Article 12(2) of the Statute. This provision otherwise requires that a state with territorial or personal jurisdiction over the crimes in question is a party to the Statute or accepts the Court's jurisdiction. ${ }^{144}$ However, the SC has the power to permit ICC investigations despite opposition from the states concerned. This should be seen in the context of Article 25 of the U.N. Charter, stipulating that SC decisions are binding for U.N. member states. ${ }^{145}$ So far, the SC has referred two situations to the OTP: Darfur in Sudan and Libya. Both referrals led to the opening of investigations. ${ }^{146}$

\section{Proprio Motu Investigations}

According to Article 15(1) of the Statute, the Prosecutor may initiate proprio motu investigations on the basis of information on crimes that may be sent by individuals or groups, countries, intergovernmental or NGOs. ${ }^{147}$ These transmissions are referred to as "[A]rticle 15 communications." 148 In addition to receiving communications, the OTP is free to examine open sources of information, which it has reportedly done. ${ }^{149}$ Such open sources may include news items in TV, radio and newspapers, as well as public reports issued by intergovernmental organizations and/or NGOs.

A specificity of proprio motu investigations is that they require the approval of a PTC, according to Article 15(3-5). ${ }^{150}$ During the Statute

142. U.N. Charter art. 39.

143. Deborah Ruiz Verduzco, The Relationship between the ICC and the United Nations Security Council, in The Law and Practice of the International Criminal Court 30, 32 (Carsten Stahn ed. 2015). See also Int'l Law Comm'n, Rep. of the Working Group on a Draft Statute for international criminal court, art. 25 and accompanying commentary, U.N. Doc. A/CN.4/L.490 (July 19, 1993); S.C. Res. 808 (Feb. 22, 1993); S.C. Res. 955 (Nov. 8, 1994). However, at least in theory, the SC's power to create ad hoc tribunals remains. See Olásolo, supra note 6, at 95.

144. Rome Statute, supra note 21, art. 12(2).

145. See U.N. Charter art. 25.

146. S.C. Res. 508, II 1 (Mar. 31, 2005); S.C. Res. 1970, II 4 (Feb. 26, 2011).

147. See OTP Regulation, supra note 40, at reg. 25(1) (a).

148. See, e.g., Office of the Prosecutor, Int'l Criminal Court, Report on Preliminary Examination Activities IIf 18, 40 (Nov. 12, 2015) [hereinafter 2015 Report on Preliminary Examination Activities (2015)].

149. See ICC Assembly of State Parties Rep. on the Activities of the Court, ICC-ASP/7/25, If 64 (Oct. 29 2008).

150. Rome Statute, supra note 21, at art. 15 . 
negotiations, some delegations opposed the idea that the Prosecutor would be able to initiate investigations independently. ${ }^{151}$ They feared such wide prosecutorial powers might be used in an improper manner. ${ }^{152}$ Conversely, the proponents of proprio motu powers argued that they would limit the control of political actors, such as states and the SC, over the activities of the Court. ${ }^{153}$ The resulting compromise was that the proprio motu powers should be subject to authorization by judges, safeguarding against arbitrariness and abuse. ${ }^{154}$

As of October 31, 2015, the OTP has reportedly received a total of 11,519 Article 15 communications, a majority of which have been deemed to fall manifestly outside the Court's jurisdiction. ${ }^{155}$ To date, the OTP has been granted authorization to open proprio motu investigations in three situations: Kenya, Côte d'Ivoire, and Georgia. ${ }^{156}$ Additionally, Article 15 communications have led the OTP to conduct preliminary examinations in twelve situations, including in Afghanistan, Colombia, Guinea, Iraq, Nigeria, Palestine, Ukraine, Comoros, Honduras, Republic of Korea, and Venezuela. ${ }^{157}$

\section{The Preliminary Examination Phase}

1. Reasonable Basis for Investigation

Once the OTP has received information about alleged crimes, whether through a state referral, a SC referral, or an Article 15 communication, the first step is to analyze and evaluate that informa-

151. Preparatory Comm. on the Establishment of an International Criminal Court, Proceedings of the Preparatory Committee during March-April and August 1996, II 151, U.N. Doc. A/51/22, (Sept. 13, 1996) [hereinafter Preparatory Committee 1996 Report].

152. Id.

153. Id. I 149. See also Danner, supra note 1, at 513-14.

154. Preparatory Comm. on the Establishment of an Int'l Criminal Court, Proposal Submitted by Argentina and Germany, Article 46, Information Submitted to the Prosecutor, U.N. Doc. A/AC.249/1998/WG.4/DP.35 (Mar. 25 1998). See also Preparatory Committee 1996 Report, supra note 151, I 150. For a more detailed summary of the drafting process, see ScHABAs, THE INTERNATIONAL CRIMINAL COURT, supra note 53, at 394-397.

155. Report on Preliminary Examination Activities (2015), supra note 148, at If 18.

156. Kenya authorization decision, supra note 139; Situation in the Republic of Côte d'Ivoire, ICC-02/11, Decision Pursuant to Art 15 of the Rome Statute on the Authorization of an Investigation into the Situation in the Republic of Côte d' Ivoire, (PTC III Oct. 3, 2011) [hereinafter Côte d' Ivoire authorization decision]; Georgia authorization decision, supra note 129.

157. See Int'l Criminal Court, Structure of the Court: Office of the Prosecutor: Preliminary Examinations (Feb. 23, 2016), https://www.icc-cpi.int/en_menus/icc/structure\%20of\% 20the\%20court/office\%20of\%20the\%20prosecutor/comm\%20and\%20ref/Pages/communications\% 20and\%20referrals.aspx. 
tion based on Article 53(1) of the Statute. ${ }^{158}$ In the case of proprio motu investigations, there are additional provisions in Article 15. ${ }^{159}$ It is this phase that is known as the preliminary examination. ${ }^{160}$

Under Articles 53(1) and 15(3), the purpose of a preliminary examination is to determine whether there is a "reasonable basis to proceed" with an investigation. In Article 53(1), this is phrased negatively: "the Prosecutor shall initiate an investigation unless he or she determines that there is no reasonable basis to proceed." ${ }^{161}$ Conversely, Article 15(3) states that the Prosecutor shall request PTC authorization of an investigation if there is a reasonable basis to proceed. ${ }^{162}$ Nonetheless, the OTP has stated that it conducts preliminary examinations in the same manner regardless of the trigger. ${ }^{163}$ As PTC II stated in the Kenya authorization decision, the standard of "reasonable basis to proceed" is the same. ${ }^{164}$ This is further clarified by Rule 48 of the RPE, stating that the OTP shall consider the factors in Article 53(1) when making a determination under Article 15(3). ${ }^{165}$

During the preliminary examination phase, the OTP does not enjoy full investigative powers. However, according to Article 15(2), and Article 53(1) combined with Rule 104(2) of the RPE, the Prosecutor may seek information from countries, organizations, or "other reliable sources," and may receive written or oral testimony. ${ }^{166}$ The OTP is free to seek as much information as it deems necessary. ${ }^{167}$ For example, if it is clear from the beginning that the crimes alleged would not fall within the jurisdiction of the Court, no further examination of the information will be necessary. ${ }^{168}$

158. Office of the Prosecutor, Int'L Criminal Court, Policy Paper on Preliminary Examinations 95 (Nov. 2013) [hereinafter Policy Paper on Preliminary Examinations].

159. See Rome Statute, supra note 21, art. 15.

160. The term preliminary examination appears in Article 15(6), relating to the opening of proprio motu investigations. However, it is used by the OTP to describe the procedure regardless of the trigger mechanism. See Policy PAPER on Preliminary Examinations, supra note 158, I 5.

161. Rome Statute, supra note 21, art. 53(1).

162. Id. art. $15(3)$.

163. Policy Paper on Preliminary Examinations, supra note 158, II 12.

164. Kenya authorization decision, supra note 139, II I 21-25. See also Côte d' Ivoire authorization decision, supra note 156, II 17-18; Georgia authorization decision, supra note 129, If 4. Accordingly, PTC authorization decisions provide interpretations of the provisions in Article 53(1) that are relevant for all preliminary examinations.

165. RPE, supra note 110 , rule 48.

166. Rome Statute, supra note 21, arts. 15(2), 53(1); RPE, supra note 110, rule 104(2).

167. Turone, supra note 136 , at 1151.

168. Id. 
Article 53(1) specifies factors for determining a "reasonable basis to proceed." First, the OTP shall consider if there is a reasonable basis to believe that a crime within the jurisdiction of the Court has been or is being committed under Article 53(1)(a). ${ }^{169}$ Second, it shall consider the issue of admissibility under Article 17 of the Statute 53(1)(b). ${ }^{170}$ Finally, if these requirements are fulfilled, the OTP shall consider if there are, nonetheless, substantial reasons to believe that an investigation would not serve the interests of justice under Article 53(1) (c). ${ }^{171}$

\section{Evidence and Jurisdiction}

Article 53(1) (a) contains two criteria: reasonable basis and jurisdiction. ${ }^{172}$ Reasonable basis is a standard of proof, which PTC I has interpreted as "a sensible or reasonable justification for a belief that a crime ... has been or is being committed." 173 The jurisdictional requirements follow from Articles 5-12 of the Statute. The criteria of reasonable basis and jurisdiction do not leave room for discretion, because they essentially depend on an objective assessment of facts and evidence. $^{174}$

\section{Admissibility of the Situation}

Article 53(1) (b), referenced in Article 17 of the Statute, establishes three criteria for admissibility: complementarity, ne bis in idem, and gravity. ${ }^{175}$ Strictly speaking, Article 17 concerns the admissibility of cases. For the purposes of assessing the admissibility of a situation, PTC II has therefore stated that "potential cases" should be identified, based on factors such as potential defendants and alleged crimes. ${ }^{176}$ These potential cases would not be binding for the OTP in its selection of cases at a later stage. In other words, the case hypotheses developed during a preliminary examination may develop, change, or be replaced during an investigation. ${ }^{177}$

169. Rome Statute, supra note 21, art. 53(1) (a).

170. Id. art. 53(1) (b)

171. Id. art. 53(1) (c).

172. Id. art. 53(1) (a).

173. Kenya authorization decision, supra note 139, II 35. See also Côte d'Ivoire authorization decision, supra note 156, II 24; Georgia authorization decision, supra note 129, If 25.

174. Turone, supra note 136, at 1152.

175. Rome Statute, supra note 21, arts. 53(1) (b), 17(1) (a) 17(1) (b), 17(1) (c), 17(1) (d).

176. Kenya authorization decision, supra note 139, II 50. See also Côte d'Ivoire authorization decision, supra note 156, II 190 and Georgia authorization decision, supra note 129, II If 36-37.

177. See also Policy PAPER on Preliminary Examinations, supra note 158, II 1 4 44-45. 


\section{a. Complementarity and $\mathrm{Ne}$ Bis in Idem}

Complementarity has been described as the fundamental concept underpinning the Statute. ${ }^{178}$ Both Paragraph 10 of the Preamble and Article 1 stipulate that the ICG shall be complementary to national jurisdictions. ${ }^{179}$ As a global criminal court with limited resources, it would be both impossible and undesirable for the ICC to completely take over the responsibilities of states to investigate and prosecute core international crimes. Rather, the Court is meant to "fill in the blanks" where national justice systems fail to act. ${ }^{180}$

The OTP, along with several scholars, have construed the principle of complementarity as having both a positive and a negative side. ${ }^{181}$ Positive complementarity is premised on the assumption, reflected in Paragraph 6 of the Statute Preamble, that the investigation and prosecution of international crimes is not only a prerogative, but a duty of states. ${ }^{182}$ As a matter of policy, the OTP has assumed a role of promoting and encouraging national investigations and prosecutions. ${ }^{183}$ This active engagement is known as positive complementarity. Negative complementarity, on the other hand, requires the ICC to refrain from taking the place of states that are already adequately investigating and prosecuting crimes within their jurisdiction.

Article 17(1) (a)-(b) provides a mechanism to ensure negative complementarity. It stipulates that a case that is being investigated or prosecuted by a state with jurisdiction is inadmissible before the ICC. ${ }^{184}$ The same applies if such an investigation has resulted in a decision not to prosecute the person concerned. ${ }^{185}$ In both cases, an exception applies if the country in question is unable or unwilling to genuinely

178. Mohamed El Zeidy, Principle of Complementarity in International Criminal LaW: Origin, Development and Practice 1 (2007).

179. See Rome Statute, supra note 21, pmbl, art. 1.

180. Schabas, The International Criminal Court, supra note 53, at 453-55.

181. See, e.g., PAPer on SOMe POlicy issues Before the Office of the Prosecutor, supra note 62, at 5. See also William Burke-White, Implementing a Policy of Positive Complementarity in the Rome System of Justice, 19 Crim. L.F. 59 (2008); Carsten Stahn, Complementarity: A Tale of Two Notions, 19 CRIM. L.F. 87 (2008).

182. Burke-White, supra note 181, at 60-61. See also Office of the Prosecutor, InT'L Criminal Court, Informal Expert Paper: The Principle of Complementarity in Practice, at 19 n.24 (2003).

183. See, e.g., OTP Strategic Plan 2012-2015, supra note 121, III 66-67. See also Informal Expert Paper, supra note 182, at 5-7.

184. Rome Statute, supra note 21, art. 17(1) (a).

185. Rome Statute, supra note 21, art. 17(1) (b). 
carry out the investigation or prosecution. ${ }^{186}$ According to an interpretation by the Appeals Chamber, the first step is to determine if any relevant national judicial activity is being carried out regarding the same person and conduct that the Court or the OTP is considering. ${ }^{187}$ If that is the case, then it will be necessary to, as a second step, assess the genuineness of such activities. ${ }^{188}$ Relevant factors for determining a state's unwillingness and inability are specified in Article 17(2) and Article 17(3). ${ }^{189}$ Unwillingness primarily refers to national proceedings that aim to shield a person from being prosecuted at the ICC, whereas inability refers to a lack of capacity within the national legal system. ${ }^{190}$

Like the issues of reasonable basis and jurisdiction, the determination of negative complementarity would appear to be essentially nondiscretionary. ${ }^{191}$ However, the assessment of inability and unwillingness may have an element of discretion, because the factors are somewhat vague. Moreover, the policy of positive complementarity is completely discretionary, and may give rise to difficult strategic issues. Imagine, for instance, a country that chooses not to investigate a crime, not because it is unable or unwilling in the sense of Article 17(2)-(3), but because it prefers that the ICC act for some other reason. Should the OTP simply abide by the wishes of that country, or encourage the country to prosecute in line with the policy of positive complementarity? This issue becomes especially relevant in the context of self-referrals.

Article 17(1)(c) relates closely to the issue of complementarity, because it concerns a situation where a state has prosecuted a person for the same conduct that the OTP is examining. However, in that case, action by the ICC is prohibited due to the principle of ne bis in idem, ${ }^{192}$

186. Rome Statute, supra note 21, art. 17.

187. Prosecutor v. Katanga, ICC-01/04-01/07-1497, Judgment on the Appeal of Mr Germain Katanga Against the Oral Decision of Trial Chamber II of 12 June 2009 on the Admissibility of the Case II 78 (ICC App. Chamber Sept. 25, 2009) [hereinafter Judgment on the Appeal of Katanga on the Admissibility of the Case].

188. Policy Paper on Preliminary Examinations, supra note 158, $\mathbb{I} 8$.

189. Rome Statute, supra note 21, arts. 17(2), 17(3).

190. See id.

191. Turone, supra note 136, at 1152. See also Judgment on the Appeal of Katanga on the Admissibility of the Case, supra note 187, If 80.

192. The principle ne bis in idem, also described by the term "doubly jeopardy," entitles a person to not "being prosecuted or sentenced twice for substantially the same offense," Black's Law Dictionary, 8th Edition, Thomson West, 2007. 
stipulated in Article 20(3) of the Statute and recognized as a human right in several international treaties. ${ }^{193}$

\section{b. Gravity}

The ICC only has jurisdiction over the most serious crimes of international concern. Consequently, all crimes listed in Article 5 are grave per se. However, Article 17(d) imposes an additional threshold of gravity in order for cases and situations to be admissible. ${ }^{194}$ In the preliminary examination phase, the PTCs have stated that the gravity assessment should be general and preliminary in nature. ${ }^{195}$ In the Kenya authorization decision, the gravity of both potential cases, and of the situation as a whole, were assessed. ${ }^{196}$ In the later Côte d'Ivoire and Georgia decisions, only potential cases were evaluated. ${ }^{197}$

In the Kenya authorization decision, PTC II interpreted gravity as having both a quantitative and a qualitative dimension. ${ }^{198}$ It stated that, for instance, it is not just the number of victims that matter, but also certain qualitative factors. ${ }^{199}$ It referred to Rules 145 (1) (c) and 2(b) (iv) of the RPE, which list aggravating circumstances for sentencing purposes. ${ }^{200}$ These factors can be summarized as the scale, nature, manner of commission, and impact of the crimes in question, and are also listed in OTP Regulation 29 as relevant for the OTP to consider in its determination of gravity. ${ }^{201}$

In its assessment of the gravity of the Situation in the Republic of Kenya as a whole, PTC II took into account the scale, manner of commission, and impact on victims of violence during the country's post-electoral period. Regarding the scale, it found that a large number of incidents

193. Rome Statute, supra note 21, art. 20(3). See, e.g., International Covenant on Civil and Political Rights, art. 14(7), Dec. 16, 1966, 999 U.N.T.S. 171; Protocol No. 7 to the Convention for the Protection of Human Rights and Fundamental Freedoms, art. 4, Nov. 22, 1984, E.T.S. 117.

194. See Kenya authorization decision, supra note 139, Il 56; Côte d'Ivoire authorization decision, supra note 156, II 201.

195. Kenya authorization decision, supra note 139, I 58; Côte d' Ivoire authorization decision, supra note 156, II 202; Georgia authorization decision, supra note 129, II 51.

196. Kenya authorization decision, supra note 139, Il 189.

197. Côte d'Ivoire authorization decision, supra note 156, If 204-205; Georgia authorization decision, supra note 129 , I 51.

198. Kenya authorization decision, supra note 139, II 62. See also Côte d'Ivoire authorization decision, supra note 156, Il 203; Georgia authorization decision, supra note 129, II 51; POLICY PAPER on Preliminary Examinations, supra note 158, III 61-65.

199. Kenya authorization decision, supra note 139, I 62.

200. Id.

201. OTP Regulation, supra note 40, reg. 29. 
had been documented and were widespread in terms of geographical location. ${ }^{202}$ Furthermore, it found the manner of commission of alleged crimes included elements of brutality. ${ }^{203}$ Finally, it took into account the considerably negative impact on victims. ${ }^{204}$

Turning to the gravity of potential cases, PTC II divided its assessment into two elements: a) the persons, and b) the crimes that would likely become the object of an investigation. ${ }^{205}$ PTC I used the same approach in its decisions on Côte d'Ivoire and Georgia. ${ }^{206}$ Regarding the first element, the PTCs considered whether the persons involved included those bearing "the greatest responsibility" for the alleged crimes. ${ }^{207}$ In the first two decisions, the Chambers noted that the individuals in question held high-ranking political and/or military positions. ${ }^{208}$ Regarding Kenya, it was noted that the alleged role of those involved included inciting, planning, financing and otherwise contributing to the organization of the crimes in question. ${ }^{209}$ As for the second element, the PTCs considered the scale of the alleged crimes. ${ }^{210}$ In the Kenya decision, the PTC once again noted that the manner of commission was marked by brutality. Similarly, PTC I brought up elements of brutality in the Georgia decision, as well as the fact that the crimes had targeted peacekeepers. ${ }^{211}$ In the Côte d' Ivoire decision, the PTC emphasized the fact that alleged crimes appeared to be part of a plan in furtherance of a policy. In sum, the PTCs found both situations to meet the gravity threshold under Article 17(1) (d). ${ }^{212}$

Though there are relevant factors to guide the assessment of gravity, the outcome will ultimately depend on how these factors are construed

202. Kenya authorization decision, supra note 139, I 190-91.

203. Such as cutting and hacking, burning victims alive, gang rapes and selecting victims on grounds of ethnicity, see id. II I 192-93.

204. Such as psychological trauma, social stigma, contraction of HIV/AIDS and other sexually transmitted diseases, unwanted pregnancies, displacement and separation of families, see id. II 194-96.

205. Id. I 59 .

206. Côte d' Ivoire authorization decision, supra note 156, I 204; Georgia authorization decision, supra note 129, II 52-53.

207. Kenya authorization decision, supra note 139, III 60, 188; Côte d' Ivoire authorization decision, supra note 156, II 204.

208. Kenya authorization decision, supra note 139, I 198; Côte d' Ivoire authorization decision, supra note 156, II 205.

209. Kenya authorization decision, supra note 139, If 198.

210. Id. II 199; Côte d' Ivoire authorization decision, supra note 156, II 205.

211. Georgia authorization decision, supra note 129, II 54-55.

212. Kenya authorization decision, supra note 139, I 200; Côte d' Ivoire authorization decision, supra note 156, II 206. 
and weighed against each other. Therefore, the gravity criterion arguably has an element of discretion. ${ }^{213}$ Indeed, when explaining its decision not to move forward with a proprio motu investigation in the Situation in Iraq, the OTP stated that it must use the gravity criterion in order to select among the many situations with which it is faced. ${ }^{214}$ This decision will be thoroughly discussed later in this Article. ${ }^{215}$ For now it suffices to note that, in the eyes of the OTP, there is certainly a degree of discretion involved in assessing the gravity of situations.

\section{The Interests of Justice}

If the criteria of reasonable basis, jurisdiction, and admissibility are fulfilled, the OTP shall consider if "taking into account the gravity of the crimes and the interests of victims, there are nonetheless substantial reasons to believe that an investigation would not serve the interests of justice." The "interests of justice" criterion is thus not a positive requirement, but a countervailing factor. ${ }^{216}$ Therefore, PTCs do not review the $\mathrm{OTP}^{\prime} \mathrm{s}$ assessment of the interests of justice when authorizing investigations. ${ }^{217}$

The reference to the "gravity of the crimes" in Article 53(1)(c) creates some overlap with Articles 53(1) (b) and 17(d). ${ }^{218}$ Additionally, the OTP is to consider the interests of victims. ${ }^{219}$ However, the broader expression "the interests of justice" is not defined anywhere in the Statute, nor has it been interpreted authoritatively by the Court. ${ }^{220}$ From its drafting history, it appears that the provision was intended to allow for prosecutorial discretion. ${ }^{221}$ When first introduced into the Statute negotiations, it was compared to the discretion of prosecutors in some domestic legal systems to refrain from prosecuting for reasons

213. See Olásolo, supra note 6 , at 136.

214. ICC Chief Prosecutor, OTP Response to Communications Received Concerning Iraq, 8 (Feb. 9, 2006), https://www.icc-cpi.int/NR/rdonlyres/04D143C8-19FB-466C-AB77-4CDB2FDEB EF7/143682/OTP_letter_to_senders_re_Iraq_9_February_2006.pdf.

215. See infra Section VII.B.2.

216. See Office of the Prosecutor, Int'L Criminal Court, Policy Paper on the Interests of Justice 2-3 (Sept. 2007).

217. Kenya authorization decision, supra note 139, II 63; Côte d' Ivoire authorization decision, supra note 156, II 207-08; Georgia authorization decision, supra note 129, If 58.

218. See Rome Statute, supra note 21, arts. 53(1) (c), 53(1) (b), 17(d); Turone, supra note 136, at 1153

219. See Rome Statute, supra note 21, art. 53.

220. Policy Paper on the Interests of Justice, supra note 216, at 2-3.

221. Schabas, The International Criminal Court, supra note 53, at 836. 
like the age or illness of a defendant. ${ }^{222}$ However, the state parties did not agree on a closed list of factors to be considered by the Prosecutor under Article 53(1) (c). This was noted by PTC I in a decision concerning the Situation in Darfur, recognizing the high degree of discretion thus left to the Prosecutor. ${ }^{223}$

Scholars have proposed a variety of factors which could considered under the "interests of justice" criterion. Some argue that the criterion could serve as a legal basis for considerations of a political or pragmatic nature, such as the practical feasibility of investigations or the prospects of state cooperation. ${ }^{224}$ Moreover, regarding the much debated issue of "justice vs. peace," 225 some argue that the OTP could use the "interests of justice" criterion in order to avoid disrupting peace processes or to defer to alternative mechanisms of transitional justice. ${ }^{226}$ However, views differ as to whether such considerations should influence the OTP's decisions. ${ }^{227}$ The OTP has presented its own views on the matter in a 2007 policy paper, which will be presented later. ${ }^{228}$

\section{The Outcome of a Preliminary Examination}

\section{a. The Decision to Open an Investigation}

If the OTP finds a reasonable basis to investigate a situation referred by a state or the SC, it can simply decide to do so under Article 53(1). ${ }^{229}$ An exception, to describe it briefly, would be if the SC decided to defer the investigation under Article $16 .^{230}$ For proprio motu investigations, however, the OTP must submit a request to the PTC under Article

222. UK Discussion Paper: International Criminal Court, Complementarity, Preparatory Committee, Il 30 (Mar. 29, 1996), http:/ / www.iccnow.org/documents/UKPaperComplementarity. pdf.

223. Situation in Darfur, Sudan, ICC-02/05-185, Decision on Application under Rule 103, PTC I, II 18 (Feb. 4, 2009), https://www.icc-cpi.int/CourtRecords/CR2009_00881.pdf.

224. Davis, supra note 5, at 182-83; Matthew R. Brubacher, Prosecutorial Discretion Within the International Criminal Court, 2 J. INT'L CRIM. JUST. 71, 81-82 (2004).

225. See supra Section IV.D.

226. See Brubacher, supra note 224, at 81; Greenawalt, supra note 3, at 664-71.

227. See, e.g., Schabas, The International Criminal Court, supra note 53, at 838-39; Human Rights Watch, The Meaning of "the Interests of Justice” in Article 53 of the Rome Statute, Human Rights Watch Policy Paper (2005), https://www.hrw.org/news/2005/06/01/meaninginterests-justice-Article-53-rome-statute.

228. See infra Section VI.B.3.a

229. See Rome Statute, supra note 21, art. 53(1).

230. See infra Section V.C.6. 
15(3). ${ }^{231}$ Under Article 15(5), a refusal by the PTC to authorize an investigation does not prevent the OTP from presenting a new request regarding the same situation, provided that it can present new facts or evidence. $^{232}$

\section{b. The Decision Not to Open an Investigation}

Should the OTP conclude that there is no reasonable basis to proceed with an investigation, it must inform those who provided the "triggering" information. For Article 15 communications, this follows directly from Article 15(6) of the Statute. ${ }^{233}$ Under Rule 105(1) of the RPE, the same obligation to inform applies to state and SC referrals. ${ }^{234}$ If the OTP's decision not to investigate is based solely on the interests of justice under Article 53(1) (c), it must also notify the PTC. ${ }^{235}$ Under Rules 40 and 105 of the RPE, all of the above mentioned notifications shall include the reasons for the OTP's conclusion. ${ }^{236}$

In the case of a state or SC referral, Article 53(3) (a) permits the SC or state to request a PTC review of the decision not to investigate. ${ }^{237}$ After such a review, the PTC may request the OTP to reconsider its decision. ${ }^{238}$ There is nothing preventing the OTP from maintaining its initial decision. However, the additional check by the PTC, along with the duty for the OTP to once more provide reasons for its decision, is meant to reduce the risk of arbitrary or unfounded negative decisions. ${ }^{239}$

The possibility of requesting a PTC review is not open to senders of Article 15 communications. ${ }^{240}$ This suggests that the OTP enjoys a higher degree of discretion with regard to proprio motu investigations. ${ }^{241}$ Some flexibility seems practical in view of the sheer amount of Article 15 communications received by the OTP, as compared to relatively few

231. See RPE, supra note 110, rule 58 (providing some additional rules for the authorization procedure, including a duty to inform concerned victims).

232. Rome Statute, supra note 21, art. $15(5)$.

233. Rome Statute, supra note 21, art. 15(6).

234. RPE, supra note 110 , rule 105 (1).

235. RPE, supra note 110 , rule $105(4)$

236. RPE, supra note 110 , rules $105,40$.

237. Rome Statute, supra note 21, art. 53(3) (a). See also RPE, supra note 110, rule 107.

238. Rome Statute, supra note 21, art. 53(3) (a). See also RPE, supra note 110, rule 108.

239. Turone, supra note 136, at 1156-57.

240. See Turone, supra note 136, at 1158.

241. This is also indicated by the use of the word "may" in Article 15(1); "The Prosecutor may initiate investigations proprio motu”. Rome Statute, supra note 21, art. 15(1). 
state and SC referrals. ${ }^{242}$ A more principled argument is that state and SC referrals carry more political weight than communications sent by individuals or NGOs. ${ }^{243}$ A referral decision by a government or by the $\mathrm{SC}$ will surely have been preceded by discussions and deliberations on a political level, whereas that is not necessarily the case with Article 15 communications. In legal terms, states and the SC are undoubtedly more powerful subjects of public international law than individuals or organizations. After all, the ICC is based on a multilateral treaty concluded by states, with important ties to the SC and the U.N. in general. Finally, practically speaking, the OTP is in some respects dependent on the cooperation of states. ${ }^{244}$

As indicated above, Article 53(3) (a) permits the U.N.S.C. or a state to request a PTC review of a decision by the OTP not to investigate. The wording of the provision suggests that it only applies when there is an express decision not to investigate, and not if the OTP simply remains inactive in respect of a situation. PTC III touched upon this issue in a decision regarding the Situation in the Central African Republic (CAR). ${ }^{245}$ Two years into the preliminary examination, the OTP had not yet reached a decision on whether or not to investigate. ${ }^{246}$ The CAR government requested PTC III to ask the OTP for clarification on this issue. ${ }^{247}$ While the PTC stated that a preliminary examination should be completed within a reasonable time period, it did not conduct a review under Article 53(3), meaning that it did not interpret the lengthy examination as a tacit decision not to investigate. ${ }^{248}$ On the other hand, it did not address the question squarely, leaving it to some extent unanswered.

If a decision not to investigate is based solely on the "interests of justice" criterion, the PTC may also decide to review the decision on its own initiative under Article 53(3)(b). ${ }^{249}$ As opposed to a review re-

242. See Fabricio Guariglia \& Emeric Rogier, The Selection of Situations and Cases by the OTP of the ICC, in The Law and Practice of the International Criminal Court 350, 356-57 (Carsten Stahn ed., 2015).

243. Id.

244. See Davis, supra note 5, at 180-82 (pointing out that the Court's relationship with civil society, though not as important as the one with states, should not be under-estimated).

245. Situation in the Central African Republic, ICC-01/05-6, Decision Requesting Information on the Status of the Preliminary Examination of the Situation in the Central African Republic, PTC III (Nov. 30, 2006), https://www.icc-cpi.int/CourtRecords/CR2007_03776.pdf.

246. Id. at 4 .

247. Id. at 5 .

248. Id. at 4 .

249. Rome Statute, supra note 21, art. 53(3) (b). See also RPE, supra note 110, rule 109. 
quested by a state or by the SC, such a review may lead the PTC to overrule the decision by the OTP. In other words, the PTC may in effect order the OTP to investigate against its will. Such a decision would, of course, significantly limit the prosecutorial discretion inherent in the "interests of justice" criterion.

\section{Security Council Deferral}

According to Article 16 of the Statute, the SC may at any point suspend investigations or prosecutions at the Court for a period of twelve months. ${ }^{250}$ This period can also be renewed. ${ }^{251}$ No case law exists regarding Article 16, however there have been four resolutions adopted by the Security Council invoking Article 16 since the entry of the Statute which may give some guidance on its applicability: Resolutions 1422 (2002), 1487 (2003), 1597 (2005) and 1970 (2011). ${ }^{252}$ Like a referral, it would require a resolution under Chapter VII of the U.N. Charter. ${ }^{253}$ The provision is meant to avoid inappropriate Court interference in the sensitive situations under examination by the SC. ${ }^{254}$ Thus, it was a way of reconciling the powers of the Court with the SC's primary responsibility for the maintenance of international peace and security. ${ }^{255}$

\section{The Investigation Phase}

\section{Preliminary Rulings Regarding Admissibility}

When opening an investigation, the OTP's first step is to notify all state parties to the Statute, along with any states that "would normally exercise jurisdiction over the crimes concerned." ${ }^{256}$ However, this duty does not apply to SC referrals. Article 18 provides an additional mechanism to ensure negative complementarity. It allows states to request the deferral of ICC investigations which they believe coincide with national investigations. Upon such an objection, the OTP can

250. Rome Statute, supra note 21, art. 16.

251. Id.

252. Yassin M. Brunger, Article 16: Deferral of Investigation or Prosecution, CommentaRY on the LAW OF THE InTERnational Criminal Court 44 (Torkel Opsahl Academic 2017).

253. U.N. Charter art. 24.

254. See Preparatory Committee 1996 report, supra note 151 I 141.

255. U.N. Charter art. 24; see also See Luigi Condorelli and Santiago Villalpando, Referral and Deferral by the Security Council, in 1 The INTERNATIONAL Criminal COURT: A COMMENTARY ON THE ROME STATUTE 627, 644 (Antonio Cassese ed., 2002).

256. Rome Statute, supra note 21, art. 18(1). 
accept it or request the PTC to authorize the investigation regardless of the state's objections. ${ }^{257}$

\section{Duties and Powers of the Prosecutor While Conducting the Investigation}

Article 54 of the Statute lists duties and powers of the Prosecutor while conducting investigations. The duties include taking appropriate measures to ensure an effective investigation and aiming to establish the objective truth by investigating incriminating and exonerating circumstances equally. ${ }^{258}$ The powers include collecting and examining evidence, requesting the presence of persons for questioning, and seeking the cooperation of a state or an intergovernmental organization. ${ }^{259}$ Accordingly, it is at this stage of the process that the OTP's full investigative powers come into play. This means it should have enough tools at its disposal to identify cases. Needless to say, this corresponds to a higher standard of proof for initiating court proceedings against a specific suspect as opposed to investigating a situation. ${ }^{260}$

\section{Selecting Cases for Prosecution}

\section{a. The Parameters of Selection}

The aim of an investigation is to identify cases. This process is selective in nature because it is not expected of the OTP to prosecute all possible cases within a situation. ${ }^{261}$ OTP Regulation 33 states that the OTP shall collect information and evidence "in order to identify the most serious crimes committed within the situation." ${ }^{262}$ It further states that the OTP shall once again consider the factors in Article $53(1)$, including reasonable basis, jurisdiction, admissibility, and the

257. See Rome Statute, supra note 21, art. 18(2); RPE, supra note 110, rules 52-57 for additional provisions.

258. On a side-note, this objective role of the Prosecutor is an example of a compromise in the Statute between the more "party-driven" adversarial and the more "judge-driven" inquisitorial model of criminal procedure. See, e.g., Schabas, The International Criminal Court, supra note 53, at 847-849; Kai Ambos, The Structure of International Criminal Procedure: 'Adversarial', 'Inquisitorial' or Mixed?, in International Criminal Justice: A Critical Analysis of Institutions and Procedures 429, 449-50 (Michael Bohlander ed., 2007).

259. Rome Statute, supra note 21, art. 54(3).

260. See infra Section V(D) (4) (a).

261. Schabas, Selecting Situations and Cases, supra note 33, at 378.

262. ОТР Regulation, supra note 40, reg. 33. 
interests of justice. ${ }^{263}$

Under Article 53(2), the Prosecutor may also conclude that there is "not a sufficient basis" for prosecution. The parameters for such a decision correspond to the ones in Article 53(1), although the term "sufficient," as opposed to "reasonable basis," suggests a higher evidentiary threshold. ${ }^{264}$ First, the OTP may find no sufficient legal and factual basis for seeking a warrant or summons under Article 58. Second, it may find the case inadmissible under Article 17. Finally, it may find that prosecution would not serve the interests of justice. Due to the overlap with Article 53(1), the assessments can be described rather briefly here. However, in the investigation phase, they are applied to concrete instead of potential cases.

\section{b. Sufficient Basis for a Warrant of Arrest or Summons to Appear}

Article 53(2) (a) refers to Article 58, which sets out the requirements for issuing an arrest warrant or a summons to appear against an individual. ${ }^{265}$ The expression "sufficient legal or factual basis" suggests that the OTP should make a comprehensive assessment of the prospects of securing warrants or summonses in the cases under investigation. ${ }^{266}$ Of course, such an assessment would be necessary even without the reference in Article 53(2)(a) if the OTP is to be successful in seeking warrants or summons.

Under Article 58, the first requirement for a warrant or summons is reasonable grounds to believe that the person has committed a crime within the Court's jurisdiction. ${ }^{267}$ This corresponds to Article 53(1) (a) in the preliminary examination phase. For an arrest warrant, there is the additional requirement that the arrest must be necessary to ensure the person's appearance at trial, to avoid obstruction of the investigation or trial, or to prevent further crimes related to the case. ${ }^{268}$

\section{c. The Admissibility of Cases}

Article 53(2) (b) requires the OTP to assess the admissibility of cases. This is also necessary because admissibility may become subject to

263. $I d$.

264. See Schabas, The International Criminal Court, supra note 53, at 839.

265. A summons to appear is an alternative to an arrest warrant if there are no specific grounds for arrest, and if the PTC finds that a summons will be sufficient to ensure the person's appearance at trial (Rome Statute, supra note 21, art. 58(7)).

266. Id

267. Rome Statute, supra note 21, art. 58(1) (a).

268. Id. art. 58(1) (b). 
judicial review under Article 19. This can happen on the Court's own motion, or upon request of an accused persons, a concerned state, or the OTP itself. ${ }^{269}$ According to Trial Chamber II, such a challenge of admissibility should normally be brought during the pre-trial phase. ${ }^{270}$

In early decisions, the PTCs treated admissibility as a prerequisite to the issuance of arrest warrants and summonses to appear under Article 58. ${ }^{271}$ Based on this, PTC I once denied an arrest warrant due to insufficient gravity. ${ }^{272}$ However, the Appeals Chamber overturned this decision upon appeal, stating that Article 58 exhaustively lists the conditions for issuing a warrant or summons. ${ }^{273}$ Although Article 19(1) allows the PTC to determine the admissibility of a case on its own motion, the Appeals Chamber held that this could be inappropriate. ${ }^{274}$ Moreover, the Appeals Chamber disagreed with the PTC's interpretation of the gravity-criterion.

The PTC decision concerned a request for arrest warrants in the cases against Thomas Lubanga and Bosco Ntaganda, who were both members of the Congolese armed group, the Union of Congolese Patriots, Patriotic Forces for the Liberation of Congo (UPC/FPLC). The PTC interpreted the gravity criterion in light of its context. It held that, because all ICC crimes are grave, the threshold in Article 17(1)(d)

269. Id. arts. 19(1), 19(2), 19(3).

270. Certain exceptions apply. See Prosecutor v. Germain Katanga and Mathieu Ngudjolo Chui, ICC-01/04-01/07-1213-tENG, Reasons for the Oral Decision on the Motion Challenging the Admissibility of the Case (Article 19 of the Statute), Trial Chamber II, II 49 (June 16, 2009), https://www.icc-cpi.int/CourtRecords/CR2009_05171.pdf.

271. Situation in the Democratic Republic of the Congo, ICC-01/04-02/06-20-Anx2, Decision on the Prosecutor's Application for Warrants of Arrest, Article 58, PTC I, II 18 (Feb. 10, 2006), https://www.icc-cpi.int/RelatedRecords/CR2008_04250.pdf (Lubanga, Ntaganda) [hereinafter Situation in the DRC, Decision on the Prosecutor's Application for Warrants of Arrest, Article 58, PTC I]; see also, e.g., Prosecutor v. Joseph Kony, Vincent Otti, Raska Lukwiya, Okot Odhiambo and Dominic Ongwen, ICC-02/04-01/05-53, Warrant of Arrest for Joseph Kony issued on 8th July 2005 as amended on 27th September 2005, PTC II, II 38 (Oct. 13, 2005), https://www.icc-cpi.int/CourtRecords/CR20 06_01096.pdf [hereinafter Prosecutor v. Joseph Kony].

272. Situation in the DRC, Decision on the Prosecutor's Application for Warrants of Arrest, Article 58, PTC I, supra note 271, I 155.

273. Situation in the Democratic Republic of the Congo, ICC-01/04-169, Judgment on the Prosecutor's Appeal Against the Decision of Pre-Trial Chamber I Entitled "Decision on the Prosecutor's Application for Warrants of Arrest, Article 58," III 42-45 (App. Chamber July 13, 2006), https://www.icc-cpi.int/CourtRecords/CR2006_01807.pdf [hereinafter Situation in the DRC, Decision on the Prosecutor's Application for Warrants of Arrest, Article 58, Appeals Chamber].

274. Id. II 48-53. In this case, the arrest warrant proceedings had been held ex parte Prosecutor only, denying the accused the possibility of making submissions on the issues of admissibility. 
must require some specific features. ${ }^{275}$ Rather than leaving the identification of relevant circumstances to the OTP's discretion, the PTC identified three specific parameters to determine if a case was sufficiently grave. ${ }^{276}$ First, it held that the conduct in question should be systematic or large-scale, causing "social alarm" to the international community. ${ }^{277}$ Second, it held that the person in question should be a "senior leader" of a state entity, organization, or armed group involved in the situation. ${ }^{278}$ Lastly, it held that the person should be one of the "most responsible" leaders for crimes within the situation. ${ }^{279}$ This requires a consideration of both the person's role within the entity and the role of that entity in the overall commission of crimes.

If upheld, the PTC's interpretation of Article 17(1)(d) would have limited ICC prosecution in a significant way. ${ }^{280}$ The focus on "senior leaders" was based on a teleological interpretation, because the PTC considered that prosecuting leaders with a high degree of influence would most effectively contribute to the prevention of crimes. ${ }^{281}$ Interestingly, the Chamber observed that the OTP had taken a similar stance in a policy paper, ${ }^{282}$ but then stated that "the adoption of these factors is not discretionary for the Prosecution because they are a core component of the gravity threshold provided for in [A] rticle 17(1)(d) of the Statute." 283 Applying the gravity criterion to the warrant requests at hand, the PTC granted the warrant against Lubanga, who was considered the highest ranking leader of UPC/FPLC. However, the PTC denied the warrant against Ntaganda because he had a lower ranking position within the group. ${ }^{284}$

275. Situation in the DRC, Decision on the Prosecutor's Application for Warrants of Arrest, Article 58, PTC I, supra note 271, I 46.

276. Id. If 64.

277. $I d$.

278. Id.

279. Id.

280. See Carsten Stahn, Judicial Review of Prosecutorial Discretion: Five Years On, in The EMERGING Practice of the International Criminal Court 247, 274-75 (Carsten Stahn \& Göran Sluiter eds., 2009).

281. Situation in the DRC, Decision on the Prosecutor's Application for Warrants of Arrest, Article 58, PTC I, supra note 271, II II 48-55.

282. Paper on SOMe policy issues before the Office of the Prosecutor, supra note 62. See infra Section VI.B.1.

283. Situation in the DRC, Decision on the Prosecutor's Application for Warrants of Arrest, Article 58, PTC I, supra note 271, III 62-63.

284. Id. ๆ 89. 
Although the Appeals Chamber initially ruled that admissibility issues should not be addressed at all, it also found it necessary to reject the PTC's interpretation of gravity. ${ }^{285}$ First, it pointed out that the large scale or systematic nature of crimes are merely aggravating circumstances of war crimes or crimes against humanity under Articles 7 and 8 , not elements of the crimes. ${ }^{286}$ Adding such elements, through an interpretation of the gravity criterion, would go against the intentions of the Statute's drafters. ${ }^{287}$ Second, concerning the exclusive focus on senior leaders, the Appeals Chamber disagreed with the PTC's statement that it would contribute to deterrence. ${ }^{288}$ On the contrary, it held that excluding any category of perpetrators, low-ranking or otherwise, from the risk of prosecution at the ICC would be in contradiction to the goal of prevention. ${ }^{289}$

In sum, the Appeals Chamber overturned an interpretation of gravity that would have significantly limited the OTP's discretion in case selection, and thus, the room for strategic choices. ${ }^{290}$ Therefore, the OTP remains free to make strategic determinations on, for example, whether or not to focus on high level perpetrators or on large scale crimes. Consequently, while the prosecution of a mid-level perpetrator might not render a case inadmissible, the OTP may consider it more or less strategically appropriate. This finding by the Appeals Chamber is persuasive, because there is little in the Statute, preparatory works, or otherwise to suggest a narrow and specific interpretation of gravity. Instead, the vagueness of the criterion suggests that it should be applied in a more casuistic and discretionary manner. At least with a strategic approach, this appears more beneficial to the ICC's objectives.

\section{Cases and the Interests of Justice}

Under Article 53(2)(c), the OTP may consider that a prosecution would not serve the interests of justice. ${ }^{291}$ The provision is somewhat more detailed than its equivalent in Article 53(1) (c). In addition to the gravity of the crime and the interests of victims, the OTP shall take into account the age or infirmity of the alleged perpetrator, as well as his or

285. Situation in the DRC, Decision on the Prosecutor's Application for Warrants of Arrest, Article 58, Appeals Chamber, supra note 273, II 54.

286. Id. II I71-72.

287. Id. 971 .

288. Id. II $73-79$.

289. Id. II 73-74.

290. See Stahn, supra note 280, at 275.

291. Rome Statute, supra note 21, art. 53(2) (c). 
her role in the alleged crime. ${ }^{292}$ It is logical that such personal considerations are more relevant at the later stage of proceedings, when the alleged perpetrator is definitely identified. However, the list of factors to consider is not exhaustive, and the assessment remains highly discretionary. ${ }^{293}$

\section{The Outcome of an Investigation}

\section{a. The Decision to Prosecute}

The first step of prosecution is to request a warrant of arrest or summons to appear under Article 58 of the Statute concerning a specific person and alleged crimes. ${ }^{294}$ Following the accused person's initial appearance at the Court, the PTC shall hold a hearing on the confirmation of charges under Article 61. Based on the hearing, the PTC shall determine whether there are "substantial grounds to believe that the person committed each of the crimes charged." 295 This is a higher evidentiary threshold than reasonable grounds. It has been interpreted by the PTC as requiring "concrete and tangible proof demonstrating a clear line of reasoning underpinning its specific allegations." ${ }^{296}$ It is incumbent on the Prosecutor to specify the charges and present sufficient evidence to support each of them. ${ }^{297}$ If the charges are confirmed, the PTC may still permit the Prosecutor to amend them (art. 61(9)). ${ }^{298}$ Additional or more serious charges, however, necessitate an additional confirmation hearing.

After the confirmation of charges, the Presidency of the Court shall constitute a Trial Chamber (art. 61(11)) to take over from the PTC. This marks the beginning of the trial phase of ICC proceedings. After this point, the Prosecutor has the possibility to withdraw charges, but not to introduce new ones.

292. Id.

293. See Schabas, The International Criminal Court, supra note 53, at 839; Turone, supra note 136 , at $1173-74$.

294. The conditions for issuing a warrant or summons have been provided supra Section V.D.3.b.

295. Rome Statute, supra note 21, art. 61(7).

296. Prosecutor v Dyilo, ICC-01/04-01/06, Decision on the Confirmation of Charges, If 39 (PTC I Jan. 29, 2007).

297. Rome Statute, supra note 21, art. 61(5).

298. Id. art. 61(9). 


\section{b. Decision Not to Prosecute}

Article 53(2) and Rule 106 of the RPE requires the OTP to notify the PTC, as well as a state or the SC that triggered the investigation, of a decision not to proceed with a prosecution. ${ }^{299}$ The notification must also contain reasons. This corresponds with the similar duty concerning decisions not to investigate. ${ }^{300}$ Like those decisions, the main purpose of a notification is to permit judicial review under Article 53(3) of the Statute. This provision applies equally to decisions on investigations as to prosecutions. Accordingly, PTC review can either be undertaken on request by a referring state or the SC, or on the Court's own initiative if the decision is based solely on the interests of justice criterion. It is only in the latter case that the PTC can overrule the OTP's decision. This has so far never occurred. ${ }^{301}$ As observed in literature, it would create a somewhat peculiar situation if the PTC ordered the OTP to prosecute against its will. ${ }^{302}$

The issue of whether PTC review under Article 53(3) requires an express decision by the Prosecutor not to prosecute came up in the Lubanga case. After PTC I issued an arrest warrant against Lubanga, an NGO called the Women's Initiative for Gender Justice ("the Women's Initiative") took issue with the limited charges brought by the OTP, especially the fact that they did not include gender-based crimes. ${ }^{303}$ The Women's Initiative filed a motion with PTC I, requesting to submit observations as amicus curiae under Rule 103(1) of the RPE. It argued, inter alia, that the PTC had inherent powers to review the OTP's selection of charges, including the persons and crimes charged. ${ }^{304}$ In response, the PTC stated that there was no reason for such a review in the absence of a decision not to prosecute. ${ }^{305}$ The conclusion was thus similar to that of PTC III in the Situation in the CAR. Both decisions

299. Rome Statute, supra note 21, art. 53(2); RPE, supra note 110, rule 106.

300. See supra Section V.C.5.b.

301. See Schabas, The International Criminal Court, supra note 53, at 843.

302. Id.

303. Situation in the Democratic Republic of the Congo, ICC-01/04-313, Request Submitted Pursuant to Rule 103(1) of the Rules of Procedure and Evidence for Leave to Participate as Amicus Curiae with Confidential Annex 2, PTC I, II I 34-36 (Nov. 10, 2006), https://www.icc-cpi. int/CourtRecords/CR2007_01670.pdf.

304. Id. II $8-20$.

305. Situation in the Democratic Republic of the Congo, ICC-01/04-373, Decision on the Request Submitted Pursuant to Rule 103(1) of the Rules of Procedure and Evidence, PTC I, II 5 (Aug. 17, 2007), https://www.icc-cpi.int/CourtRecords/CR2007_03714.pdf [hereinafter Situation in the DRC, Decision on Request Pursuant to Rule 103(1), PTC I]. 
indicate a reluctance to interpret the OTP's inactivity as an implicit decision not to investigate or prosecute under Article 53(3), and thus a certain respect for prosecutorial discretion. ${ }^{306}$

\section{E. Summary: What Room is There for Discretion in Situation and Case Selection?}

On initial reflection, the situation and case selection process is intricate and repetitive. The OTP is required to make similar assessments on issues such as jurisdiction, complementarity, gravity, and the interests of justice at several different stages of the process. This may appear ineffective, especially because the early assessments need to be preliminary in nature. However, it is natural that assessments become more specific as investigations narrow down on cases. Also, the evidentiary threshold gradually rises, starting with the "reasonable basis to proceed" in Article 53(1) and leading to the "substantial grounds" for confirmation of charges in Article 61.

After the overview of the process, situation and case selection will be summarized, with a view to responding to sub-question two from this Article's Introduction: what room does the legal framework leave for prosecutorial discretion in situation and case selection?

\section{Situation Selection}

Situation selection starts with the trigger mechanisms in Article 13. Leaving aside the OTP's yet unused possibility to base a proprio motu investigation on information from open sources, outside actors such as countries, the SC, or NGOs provide the initial information on potential situations. The fact that the triggers concern situations instead of cases allows a greater degree of prosecutorial discretion. In fact, during the drafting of the Statute, a purpose of making situations the object of referrals was to limit state parties' and the SC's influence over the precise conduct and individuals to be prosecuted at the ICC. ${ }^{307}$ In this respect, prosecutorial discretion was favored over political control.

The system appears to create somewhat of a hierarchy between the three trigger mechanisms, with SC referrals at the top and proprio motu investigations at the bottom. ${ }^{308}$ SC referrals give rise to so called "fast

306. However, the decisions have not ruled out such interpretations per se. See Stahn, supra note 280 , at $277-78$.

307. See Preparatory Committee 1996 report, para 151. See also Olásolo, supra note 6, at 99.

308. See Chris Gallavin, Prosecutorial Discretion Within the ICC: Under the Pressure of Justice, 17 CRIM. L. F. 43, 49-50 (2006). 
track" proceedings, requiring neither PTC authorization nor a notification to states under Article $18 .^{309}$ State referrals do not require PTC approval, but instead a notification to states that may lead to preliminary objections on admissibility. If the OTP decides not to investigate or prosecute, the $\mathrm{SC}$ and states both have the possibility to request a PTC review. The SC has the additional power of deferral in Article 16, making it the outside actor with the highest degree of formal influence over investigations. However, it lacks the power to direct the OTP's action more precisely.

Proprio motu investigations are subject to a higher degree of judicial control, requiring both PTC authorization under Article 15 and notification to states under Article 18. The PTC authorization is especially significant, because it deprives the OTP of the "final say" in the situation selection process. At the same time, senders of Article 15 communications are unable to challenge a decision by the OTP not to investigate. Consequently, the OTP exercises comparatively less influence over a decision to investigate proprio motu, but more influence over a decision not to investigate.

Although state and SC referrals enjoy a more privileged position than Article 15 communications, the parameters for deciding to investigate are essentially the same regardless of the trigger. The criterion that is most clearly discretionary is "the interests of justice." The concept is intentionally vague and has not been authoritatively defined in the Statute nor by the Court. ${ }^{310}$ At the same time, an application of the criterion may become subject to PTC review. Like PTC authorization of proprio motu investigations, this is likely a way of balancing wide prosecutorial discretion with a degree of judicial control.

Although it appears more objective, the gravity criterion also has an element of discretion, mainly due to its vagueness. PTC authorization decisions provide some guidance; however, the many ways in which gravity factors can be assessed and weighed against each other leaves considerable room for strategic considerations. Furthermore, when gravity is interpreted less as a minimum requirement, and more as a parameter for prioritizing the situations worthiest of the OTP's attention, the discretionary element is clear. To some extent, the complementarity criterion also involves some discretion, though rather in its function as a positive concept than as a negative requirement.

309. Olásolo supra note 6, at 100-101.

310. Policy Paper on the Interests of Justice, supra note 216, at 2-3. 


\section{Case Selection}

The opening of an investigation marks the conclusion of the situation selection process. With its full investigative powers activated, the OTP is now expected to narrow down on specific incidents and persons, i.e., cases. Prior to the issuance of an arrest warrant or summons to appear, investigations formally concern situations. However, considering that situations are made up of "potential cases," the process of case selection in a sense has already begun in the preliminary examination phase. However, it is in the investigation phase that the process is completed for the purposes of bringing a case to trial.

Compared to situation selection, case selection is more explicitly selective. Assuming that a number of cases could be identified within any given situation, there is a clear need to prioritize. Because of the lack of directions from outside actors, the Prosecutor selects cases almost completely independently. However, the legal thresholds are higher. Provided that the investigation culminates in charges against an individual, the OTP will need to present a case that is sufficiently supported by evidence. Therefore, the availability of evidence will likely have a considerable impact on the selection of cases.

The remaining parameters in Article 53(2) and 53(1), read in conjunction with OTP Regulation 33, serve both as requirements and as more discretionary parameters of selection. As in situation selection, discretion may be exercised particularly in the interests of justice and gravity criteria. While the process is subject to some judicial control, case law suggests a will to avoid "over-reaching." In rejecting the PTC's narrow interpretation of gravity, the Appeals Chamber preserved prosecutorial discretion in this respect. Similarly, the PTC decision on the Women's Initiative motion in the Lubanga case indicates a reluctance to review the selection of specific charges.

\section{ICG Prosecutorial Strategy and Policy}

\section{A. Inventory of Policy and Strategy Documents}

According to Article 14 of the OTP Regulations, the OTP shall make public its strategy and, as appropriate, additional policy papers on "key principles and criteria" of the strategy. ${ }^{311}$ This regulation was essentially a codification of the OTP's existing practice of publication. Prior to its adoption in 2009, the OTP had published an initial document on

311. OTP Regulations, supra note 40. 
policy issues in $2003,{ }^{312}$ followed by a more comprehensive strategy document in $2006 .{ }^{313}$ It had also adopted a policy paper on the interest of justice criterion in Article 53(1)(c) and (2) (c) of the Statute. ${ }^{314}$ Following the adoption of the regulation, the Office has published three strategic plans, three finalized policy papers, and a draft policy paper. Based on the categorization in Regulation 14, the policy and strategy documents published to date by the OTP can be summarized as follows:

I. Strategy documents

1. Report on Prosecutorial Strategy (September 2006) (15 $^{315}$

2. Prosecutorial Strategy 2009-2012 (February 2010) ${ }^{316}$

3. Strategic Plan 2012-2015 (October 2013) 317

4. Strategic Plan 2016-2018 (July 2015) ) $^{318}$

II. Policy papers on specific issues

1. Paper on some Policy Issues before the OTP (September 2003) $)^{319}$

2. Policy Paper on the Interests of Justice (September 2007) ${ }^{320}$

3. Policy Paper on Victims' Participation (April 2010) ${ }^{321}$

4. Policy Paper on Preliminary Examinations (November 2013) ${ }^{322}$

5. Policy Paper on Sexual and Gender-Based Crimes (June 2014) ${ }^{323}$

6. Draft Policy Paper on Case Selection and Prioritization (February 2016) $)^{324}$

This categorization is simply a way of aiding the presentation of the documents. The main difference between the categories is that strategy

312. PAPER ON SOME POLICY ISSUES BEFORE THE OFFICE OF THE PROSECUTOR, supra note 62.

313. 2006 REPORT ON PROSECUTORIAL STRATEGY, supra note 65.

314. POLICY PAPER ON THE INTERESTS OF JUSTICE, supra note 216.

315. 2006 REPORT ON PROSECUTORIAL STRATEGY, supra note 65.

316. PROSECUTORIAL STRATEGY 2009-2012, supra note 121.

317. OTP STRATEGIC PLAN 2012-2015, supra note 121.

318. OTP STRATEGIC PLAN 2016-2018, supra note 121.

319. PAPER ON SOME POLICY ISSUES BEFORE THE OFFICE OF THE PROSECUTOR, supra note 62.

320. POLICY PAPER ON THE INTERESTS OF JUSTICE, supra note 216.

321. Office of the Prosecutor, Int'l Criminal Court, Policy paper on victims' participaTION (2010) [hereinafter POLICY PAPER ON VICTIMS' PARTICIPATION].

322. POLICY PAPER ON PRELIMINARY EXAMINATIONS, supra note 158.

323. Office of the Prosecutor, Int'l Criminal Court, policy paper on sexual and GENDER-BASED CRIMES (2014) [hereinafter POLICY PAPER ON SEXUAL AND GENDER-BASED CRIMES].

324. Office of the Prosecutor, Int'L Criminal Court, DRAFt POLicy PAPER on CASE SElection AND PRIORITIZATION (2016) [hereinafter POLICY PAPER ON CASE SELECTION AND PRIORITIZATION]. 
documents are more comprehensive plans for the OTP's work. They include policy issues, but also other issues such as internal organization, budget management and public outreach. In addition, the strategy documents establish objectives and attempt to evaluate progress.

The policy paper from 2003 only covers a few select policy and organizational issues. However, it also constituted a first attempt at formulating a prosecutorial strategy. Therefore, it will be presented separately and before the strategy documents.

\section{B. General Content of the Strategy and Policy Documents}

\section{Initial Policy Paper (2003)}

A few months into the tenure of first head Prosecutor Luis Moreno Ocampo, and before any investigations had been launched, the OTP issued its first policy paper. ${ }^{325}$ At the outset, the Office considered that it would face specific challenges as compared to national prosecutorial authorities. ${ }^{326}$ Unlike these authorities, the OTP would not necessarily be supported by a state with control over territory and with enforcement agencies at its disposal. ${ }^{327}$ The difficulty of securing necessary state cooperation would be further compounded if the crimes under investigation had been committed by agents or even leaders of a state. $^{328}$ For this reason, the OTP considered that it would need to select situations carefully. ${ }^{329}$ The possibilities of carrying out investigations would in practice depend on various factors, including the nature and stage of conflict, the security situation, and the prospects of securing necessary cooperation and arrests. ${ }^{330}$ Consequently, these factors should be considered when choosing whether to open an investigation.

The Office also discussed the selection of cases and, more specifically, of defendants. ${ }^{331}$ Firstly, it held that the Court's global character and limited resources would necessitate prioritization. ${ }^{332}$ Secondly, it referred to Paragraph 4 of the Preamble and Article 5 of the Statute, stating that the Court shall have jurisdiction over the most serious

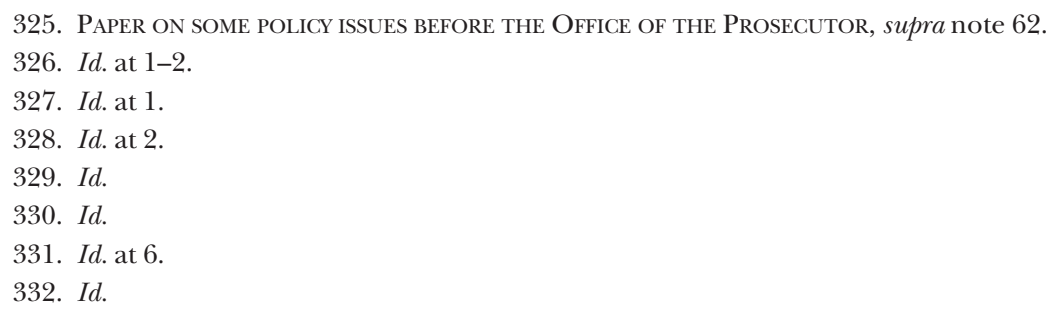


crimes of international concern. ${ }^{333}$ The OTP also referred to the gravity criterion in Article $17(\mathrm{~d}) .{ }^{334}$ It drew the preliminary conclusion that, as a general rule, it should focus its efforts on those bearing the greatest responsibility for crimes, such as leaders of a state or organization. ${ }^{335}$

The OTP recognized that a strategy of focusing on a specific category of perpetrators risked creating a so called "impunity gap" for lower level perpetrators. ${ }^{336}$ To avoid this, it stated that it might sometimes need to broaden its focus. ${ }^{337}$ Mainly, however, it held that the Court and the international community should seek to encourage national prosecutions of lower-level perpetrators. ${ }^{338}$ Accordingly, the policy on selecting defendants was linked to the principle of complementarity. ${ }^{339}$ This principle was also construed quite restrictively, as the OTP held that it would only investigate and prosecute in the place of states who were clearly unable or unwilling to do so themselves. ${ }^{340}$

\section{Strategy Documents}

\section{a. Strategy Documents under Luis Moreno Ocampo (2006-2012)}

Beginning in 2006, the OTP has continuously issued more comprehensive strategy documents. The first two, published during the tenure of first Prosecutor Luis Moreno Ocampo, will be presented together, followed by the latest two, published under current Prosecutor Fatou Bensouda.

The first strategy document, published in 2006, established five strategic objectives, relating to the quality and quantity of investigations and prosecutions and the cooperation with states and organizations. ${ }^{341}$ In the 2010 document, these objectives were largely retained. ${ }^{342}$ Furthermore, the 2006 document established three principles for the work of the OTP: a) positive complementarity; b) focused investigations and

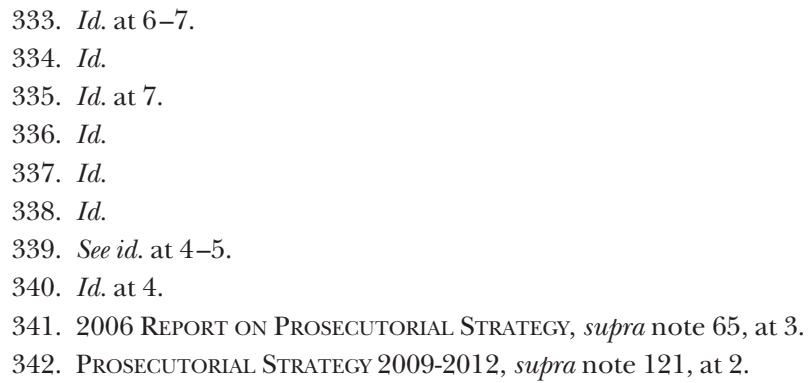


prosecutions, and c) maximizing preventative impact. ${ }^{343}$ The 2010 document added a fourth principle, d) addressing the needs of victims. $^{344}$

The principle of positive complementarity builds on the reasoning in the 2003 policy paper. Encouraging national investigations and prosecutions has since then been discussed in all strategy documents. ${ }^{345}$ It has also been linked to the more general issue of cooperating and coordinating with national justice systems and other actors, such as NGOs and international organizations, in support of both ICC and national efforts. $^{346}$

The principle of focused investigations and prosecutions also builds on statements in the 2003 paper on case selection. In order to ensure a focus on the most serious crimes and the most responsible perpetrators, the 2006 document stated that cases would be selected in a sequential manner according to their gravity. ${ }^{347}$ Considering the Court's limited capacity, the OTP would aim to select a representative sample of the gravest cases within each situation. By choosing a small number of cases, the OTP held it would be able to carry out short investigations and expeditious trials, limiting the number of witnesses, minimizing security risks, and increasing cost-effectiveness. In the 2010 document, the policy was specifically linked to the selection of defendants. The OTP stated that it would focus on "those situated at the highest echelons of responsibility, including those who ordered, financed or otherwise organized the alleged crimes."348

By the principle of maximizing preventative impact, the OTP meant that it would aspire to achieve such an impact as early as possible. It was quite optimistic about the prospects for this, holding that the effect could be achieved simply by monitoring a situation or announcing an investigation. Moreover, it believed that the effect would stretch wider than the situations under investigations, affecting potential perpetrators worldwide. ${ }^{349}$

343. 2006 Report on Prosecutorial Strategy, supra note 65, at 4-6.

344. Prosecutorial Strategy 2009-2012, supra note 121, at 6-7. Thus, the issue of victim's interests went from being framed as a strategic objective to a principle.

345. Prosecutorial Strategy 2009-2012, supra note 121, at 4-5; OTP Strategic Plan 2012-2015, supra note 121, at 28-29; OTP STRATEGIC Plan 2016-2018, supra note 121, at 32-35.

346. OTP Strategic Plan 2012-2015, supra note 121, at 28-29.

347. 2006 Report on Prosecutorial Strategy, supra note 65, at 5-6.

348. Prosecutorial Strategy 2009-2012, supra note 121, at 5-6.

349. 2006 Report on Prosecutorial Strategy, supra note 65, at 6; Prosecutorial Strategy 2009-2012, supra note 121, at 7. 
In summary, during its first years, the OTP seems to have been concerned with how to make the most of its limited capacity and resources to achieve the greatest possible impact. The principles of positive complementarity, focused investigations and prosecutions, and maximizing the preventative impact all follow in that vein.

\section{b. Strategy Documents under Fatou Bensouda (2012-2018)}

The strategic plan published in 2013, the year after Prosecutor Bensouda took office, brought a shift in prosecutorial strategy. The OTP had evaluated its past performance, noting acceptable progress for a "start-up phase." "350 Looking forward, it considered that the demands on the OTP would remain very high, particularly given its limited resources. It noted that ICC judges were expecting it to submit more substantial evidence at an earlier stage of proceedings. Most likely, this was in reference to the decisions by PTCs to refuse confirming the charges against Bahar Idriss Abu Garda ${ }^{351}$ (Darfur), Callixte Mbarushimana ${ }^{352}$ (DRC), Henry Kiprono Kosgey, ${ }^{353}$ and Mohammed Hussein $A i^{354}$ (Kenya). In all four cases, the PTC did not find sufficient evidence to support individual criminal responsibility. These decisions were surely seen as setbacks for the OTP, especially in light of its policy of focusing on a small number of cases. Indeed, the OTP stated in the 2013 plan that it would need to focus more on "success in court" in order to ensure credibility and long-term impact. ${ }^{355}$

Furthermore, the OTP noted that the crimes it investigated often took place within complex organizational structures. ${ }^{356}$ This created the problem, familiar to investigators of organized crime, that the most responsible persons were able to distance themselves from the crimes and avoid prosecution. Compared to national authorities, the OTP also lacked access to so called specialized investigative techniques, such as

350. Prosecutorial Strategy 2009-2012, supra note 121, at 11-12.

351. Prosecutor v. Bahar Idriss Abu Garda, ICC-02/05-02/09-243-Red, Decision on the Confirmation of Charges, Public Redacted Version, PTC I, II 233 (Feb. 8, 2010), https:/ /www.icccpi.int/CourtRecords/CR2010_00753.pdf [hereinafter Prosecutor v. Bahar Idriss Abu Garda].

352. Prosecutor v. Mbarushimana, ICC-01/04-01/10, Decision on the Confirmation of Charges, If 303 (Dec. 16, 2011).

353. Prosecutor v. Ruto, ICC-01/09-01/11, Decision on the Confirmation of Charges Pursuant to Article 61 (7) (a) and (b) of the Rome Statute (Jan. 23, 2012).

354. Prosecutor v. Muthaura, ICC-01/09-02/11, Decision on the Prosecutor's Application for Summonses to Appear, II 427, (Jan. 23, 2012).

355. OTP StRategic Plan 2012-2015, supra note 121, at 12.

356. Id. at 13 . 
infiltration or voice interception, making the investigations even more challenging.

In light of the identified challenges, the OTP introduced strategic changes at three levels: policy, resources, and organization. At the policy level, the principle of focused investigations and prosecutions was replaced with "in-depth, open-ended investigations, while maintaining focus to avoid over-expanding the investigations at the expense of efficiency." 357 The "in-depth" aspect of investigations meant that the collection of evidence would be diversified and expanded so as to better meet the Court's standards. ${ }^{358}$ The "open-ended" aspect meant that the OTP would work on multiple case hypotheses throughout investigations, avoiding ruling out cases too soon. Finally, the OTP would attempt to be as trial-ready as possible before requesting the confirmation of charges. This new strategy would be applied to the newly opened investigation in Mali. ${ }^{359}$

Furthermore, if it would prove too difficult to convict the most responsible perpetrators, the OTP would instead adopt an upwardsbuilding strategy. It would start with a select number of mid- to high-level perpetrators, aiming to build a case against the persons at the top of the chain. This is reminiscent of the strategy used by the Prosecutor of the ICTY. ${ }^{360}$ The OTP would even consider prosecuting low-level perpetrators, but only if their conduct had been "particularly grave" and "acquired extensive notoriety." 361

In the 2015 strategic plan, the OTP maintained the new approach to investigations and prosecutions. ${ }^{362}$ It noted that the policy shift had created a promising trend, as charges were on average more likely to be confirmed. ${ }^{363}$ However, it argued that its need to prioritize quality over quantity had limited its ability to react to on-going crimes. ${ }^{364}$ This had in turn negatively impacted perceptions of the Office's performance. ${ }^{365}$ Therefore, as in 2013, the OTP argued that it would ideally

357. Id.

358. Id.

359. Id. at 34 .

360. See de Vlaming, supra note 20, at 550. The Prosecutor of the ICTR was able to target high-level perpetrators more directly, largely due to the cooperation of the Rwandan government. See deGuzman \& Schabas, supra note 7, at 139.

361. OTP Strategic Plan 2012-2015, supra note 121, at 14.

362. OTP Strategic Plan 2016-2018, supra note 121, at 15-16.

363. $I d$. at 5 .

364. Id. at 7 .

365. Id. 
require a substantial increase in resources. ${ }^{366}$

In summary, the later strategy of the OTP seems to reflect a developing Office which is gradually learning from its successes and failures, as well as from the evolving practice of the Court. The policy shift reveals the difficulties of balancing quality, as in well-founded cases that are likely to hold in court, and quantity, as in a high number of cases pursued. Starting in 2013, the OTP considered it would need to focus on quality in the first place. In order to also ensure quantity, a resource increase would be needed, something that the OTP did not press for in earlier strategy documents. This reflects a more ambitious approach to what the ICC could and should achieve, especially when it comes to the number of cases pursued within a situation.

\section{Policy Papers}

\section{a. Policy Paper on the Interests of Justice (2007)}

The interests of justice criterion in Article 53(1)(c) and (2) (c) of the Statute was the first issue to which the OTP dedicated a special policy paper, likely due to the ambiguity and discretionary nature of the term. ${ }^{367}$ However, as the OTP admitted, the clarification was limited. ${ }^{368}$ The paper did not give a full account of factors that could fall under the interests of justice, because these would vary from case to case. Instead, it discussed the criterion in a more general sense, lifting what the OTP considered to be key aspects.

First, the OTP held that the interests of justice criterion should only be applied under exceptional circumstances. ${ }^{369}$ In fact, it argued that there was a presumption in favor of investigating or prosecuting if other legal requirements were fulfilled. Firstly, the OTP noted that its role under the Statute was to investigate and prosecute those responsible for ICC crimes. Furthermore, it pointed to a "consistent trend" of imposing a legal duty on states to prosecute core international crimes. ${ }^{370}$ In that regard, it invoked Paragraph 6 of the Statute Preamble, along with statements by the U.N. Under-Secretary-General for Legal Affairs

366. OTP Strategic Plan 2012-2015, supra note 121, at 14-15; OTP Strategic Plan 2016-2018, supra note 121, at 7-8, 35-36.

367. See Danner, supra note 1, at 543 (holding that "a prime goal of the prosecutorial guidelines should be to give content to this nebulous phrase" (emphasis added)).

368. Policy Paper on the Interests of Justice, supra note 216, at 1.

369. Id. at $2-4$.

370. Id. at 3 . 
and by the President of the $\mathrm{SC}^{371}$ as well as a report adopted by the U.N. Human Rights Commission. ${ }^{372}$ The main thrust of the OTP's reasoning seems to be that it is unacceptable for core international crimes to go unpunished. Therefore, both states and the ICC have a principal duty to act when such crimes fall under their respective jurisdictions, following the principle of complementarity.

In support of its argument, the OTP also invoked the objects and purposes of the Statute. ${ }^{373}$ Specifically, it cited the purposes of ending impunity, preventing crimes, and contributing to lasting respect for international justice. While generally speaking in favor of investigations and prosecutions, the OTP argued that these objectives also provided guidance to the rare instances where prosecutorial action would not be in the "interests of justice." ${ }^{374}$ As an example, it imagined a situation where a suspect's rights would be violated "in a manner that could bring the administration of justice into disrepute." 375

The OTP continued by discussing the explicit factors to be considered under Article 53(1)(c) and (2)(c): the gravity of crimes, the interest of victims, and, regarding prosecutions, the particular circumstances of the accused. ${ }^{376}$ Concerning gravity, the OTP noted the overlap with the gravity criterion in Article 17(1)(d), holding that this revealed the central importance of the factor. ${ }^{377}$ As for the interests of victims, it stated that these would generally weigh in favor of prosecution. However, it recognized the possibility of divergent views among victims. It also held that due consideration should be given to factors such as safety, well-being, dignity, and privacy of victims. ${ }^{378}$ Finally, as examples of personal circumstances that might compel it to abstain from prosecuting a particular person, the OTP cited terminal illness

371. Both statements originated from the same meeting. See Press Release, Security Council, Security Council, Following Day-Long Debate, Underscores Critical Role of International Law in Fostering Global Stability, Order, U.N. Press Release SC/8762 (June 22, 2006) (quoting Nicolas Michel, U.N. Under Secretary-General for Legal Affairs); see also U.N. President of the S.C., Statement by the President of the Security Council, U.N. Doc. S/PRST/2006/28 (June 22, 2006).

372. Rep. of the Independent Expert to Update the Set of Principles to Combat Impunity, Diane Orentlicher, Addendum, Updated Set of Principles for the Protection and Promotion of Human Rights Through Action to Combat Impunity, U.N. Doc. E/CN.4/2005/102/Add.1 (Feb. $8,2005)$.

373. Policy Paper on the Interests of Justice, supra note 216, at 4.

374. Id.

375. Id. at 4 n.8.

376. Id. at $4-7$.

377. Id. at 5 .

378. Id. 
and serious human rights violations. ${ }^{379}$

The OTP went on to discuss some considerations that frequently arose as suggestions on what the interests of justice could entail. ${ }^{380}$ Firstly, it brought up the relevance of other justice mechanisms, such as truth seeking, reparations programs and traditional justice mechanisms. The OTP held that such mechanisms could play a "complementary role" in the pursuit of justice, and that it would seek to support such efforts. ${ }^{381}$ It is not entirely clear how this reasoning applies to the interests of justice. Possibly, because the OTP views other justice mechanisms as merely complementary, their existence would not prompt it to abstain from investigating or prosecuting under Article $53(1)(\mathrm{c})$ or $(2)(\mathrm{c})$.

Thereafter, the OTP addressed the much discussed question on the relationship between the interests of justice and the interests of peace. ${ }^{382}$ At the outset, it considered that the ICC was based on the premise that justice and peace are reconcilable interests, and that justice is necessary for sustaining peace. Furthermore, it held that, while the interests of justice was a broader concept than criminal justice, it was not broad enough to embrace "all issues related to peace and security." 383 The OTP argued that considering such issues was not its responsibility, but fell under the purview of "other institutions." ${ }^{384}$ Specifically, it referred to the SC, and to its power of deferral under Article 16 of the Statute.

In summary, the clarification offered by the policy paper was indeed limited. In comparison to the OTP's first policy paper from 2003, it is noteworthy that the practical conditions for investigations or prosecutions, such as the level of cooperation and security situation, were not invoked as possible considerations under the interests of justice.

\section{b. Policy Paper on Victims' Participation (2010)}

The paper on victim's participation was mainly concerned with the interpretation of Article 68(3) of the Statute, stipulating that the Court shall permit the views and concerns of victims to be presented and considered at various stages of proceedings. ${ }^{385}$ Of relevance here is mainly a reference to the policy of focused investigations and prosecu-

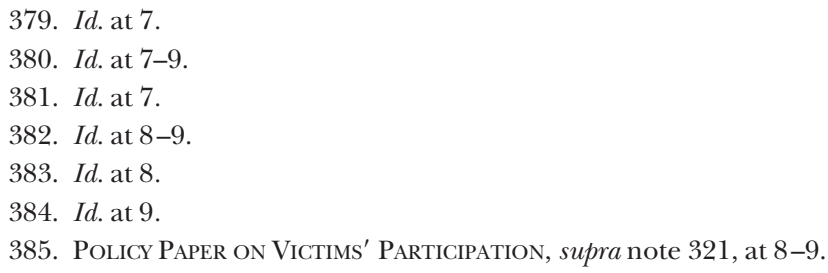


tions. ${ }^{386}$ Article $68(3)$ only concerns victims with a personal interest in the specific cases chosen by the OTP. ${ }^{387}$ Because the OTP's policy then was to pursue a limited number of cases, it acknowledged that there would be victims of other ICC crimes within the situation that would not enjoy the full rights of participation. Therefore, it would seek to address the interests of victims more broadly in other ways, for example in assessing the gravity of crimes, and for the purposes of reparations. ${ }^{388}$

\section{c. Policy Paper on Preliminary Examinations (2013)}

The paper on preliminary examinations described the OTP's policy and practice during the situation selection process. It establishes general principles and objectives for the process, discusses the different statutory criteria and describes the practical arrangements of conducting a preliminary examination. ${ }^{389}$

The general principles to guide the situation selection process are independence, impartiality, and objectivity. ${ }^{390}$ Prosecutorial independence under Article 42 of the Statute was given a broad meaning. The OTP held that beyond not taking instructions from other parties, its decisions would not be influenced at all by the wishes of others, not even in the purpose of securing cooperation. ${ }^{391}$ Regarding impartiality, it rejected the notion that all "sides" to a conflict must necessarily be targeted to an equal extent. 392

After stating these general principles, the OTP went on to discuss the different statutory criteria for situation selection under Article 53(1). ${ }^{393}$ In particular, it elaborated on relevant factors for assessing complementarity and gravity. ${ }^{394}$ It reaffirmed the importance of gravity in both situation and case selection, because it viewed it as an objective criterion.

Regarding the interests of justice, some points from the 2007 policy paper were reiterated. ${ }^{395}$ The OTP underlined the exceptional nature of the criterion, as well as the irrelevance of "the interests of peace."396

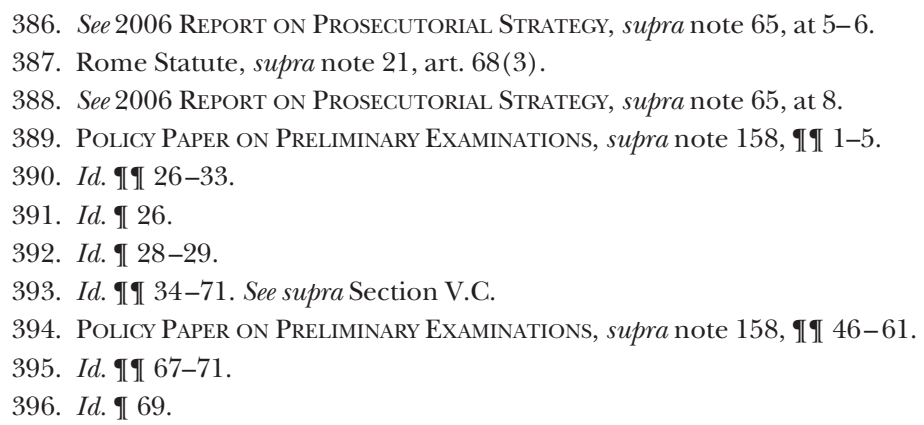


It added that "the interests of justice provision should not be considered a conflict management tool requiring the Prosecutor to assume the role of a mediator in political negotiations. ${ }^{397}$ Moreover, the OTP now squarely addressed the issue of practical feasibility, stating that it was not a factor to consider under the interests of justice. The reason was that it might lead to inconsistency, or even give opponents of the ICC a reason to engage in obstructionism. ${ }^{398}$

\section{d. Policy Paper on Sexual and Gender-Based Crimes (2014)}

The paper on sexual and gender-based (SGB) crimes falls in line with a current strategic goal of the OTP: to pay particular attention to this category of crimes. ${ }^{399}$ It is based on the assessment that these are particularly grave crimes whose investigation and prosecution entail specific challenges, such as underreporting and stigma. ${ }^{400}$ In a broader sense, the paper recognizes the need for comprehensive gender analysis in carrying out its work. Thus, it deals with a wide range of issues, including the interpretation of crime definitions, investigation practices, witness protection, and even internal personnel policies.

For the present purposes, it is especially interesting to note the link made between SGB crimes and the concept of gravity. The OTP stated that it considers SGB crimes to be among the gravest under the Statute. ${ }^{401}$ When assessing their gravity under Article 53, the Office intends to take into account their multifaceted character and great negative impact on victims. ${ }^{402}$ Moreover, while reiterating its strategy of focusing on mid- to high-level perpetrators, the OTP cited SGB crimes as examples of particularly grave or notorious crimes which might warrant the prosecution of low-level perpetrators. ${ }^{403}$

\section{e. Draft Policy Paper on Case Selection and Prioritization (2016)}

At the time of writing, the OTP is in the process of developing a policy paper on the process of case selection. In February 2016, a draft

397. Id.

398. Id. I 70 .

399. OTP Strategic Plan 2012-2015, supra note 121, at 27. See OtP Strategic Plan 2016-2018, supra note 121, at 19 (reiterating this goal); see also POLICY PAPER ON SEXUAL AND GENDER-BASED CRIMES, supra note 323.

400. Policy Paper on Sexual and Gender-based Crimes, supra note 323, at 10, 24-25.

401. Id. at 23-24.

402. Id.

403. Id. at 14. 
paper was released for external consultation. ${ }^{404}$ While it should be borne in mind that the paper is not yet in its final form, its subject matter makes it relevant to discuss here. At the outset, the OTP noted the close correlation of situation and case selection, and that the new policy paper will complement the policy paper on preliminary examinations. ${ }^{405}$ However, it stated that case selection is more discretionary. With the new policy paper, the OTP would aim to present "sound, fair and transparent principles and criteria" to guide the exercise of that discretion. ${ }^{406}$

As a matter of methodology, the OTP stated that it will develop case selection plans for each situation under investigation, identifying and developing case hypotheses. ${ }^{407}$ These plans will build on the conclusions of the preliminary examination phase, and will be subject to review throughout the investigation phase. The OTP went on to state that the general principles of independence, impartiality, and objectivity-presented for the purposes of situation selection in the policy paper on preliminary examinations-also apply to case selection. ${ }^{408}$ Subsequently, the legal criteria for case selection were presented: jurisdiction, admissibility, and the interests of justice. Regarding the interests of justice, the exceptionality of the criterion was reiterated. ${ }^{409}$

It was in the subsequent part of the draft paper that the OTP provided some new insights into the parameters of case selection. Firstly, it presented the following "case selection criteria": the gravity of crimes, the degree of responsibility of alleged perpetrators, and the potential charges. ${ }^{410}$ Regarding gravity, a distinction was made between its function as an admissibility criterion under Article 17(1)(d) and as a more general parameter for selection. For the latter purposes, the OTP stated that a higher threshold can be applied. ${ }^{411}$

When it comes to the selection of defendants, the "upwardsbuilding" strategy presented in the 2013 strategic plan was reiter-

404. Press Release, Office of the Prosecutor, Int'l Criminal Court, ICC Prosecutor, Fatou Bencouda, Issues Draft Policy Paper on Case Selection and Prioritization, for Comment, ICC-CPI-20160229-PR1192 (Feb. 29, 2016), https://www.icc-cpi.int/en_menus/icc/press\%20and\% 20media/press\%20releases/Pages/pr1192.aspx.

\footnotetext{
405. Draft Policy Paper on Case Selection and Prioritization, supra note 324, at 3-4.

406. Id. at 4 .

407. Id. at 5-6.

408. Id. at 6-8; see Policy Paper on Preliminary Examinations, supra note 158, If If 25-33.

409. Draft Policy Paper on Case Selection and Prioritization, supra note 324, at 11.

410. Id. at 11-14.

411. Id. at 12 .
} 
ated. ${ }^{412}$ It was also clarified that the degree of responsibility is not solely dependent on a person's de jure position within a hierarchical structure, but also on factors such as the nature of the alleged conduct and the degree of participation or intent. Finally, regarding the selection of charges, the OTP reiterated its aim to select a representative sample of "the main types of victimization" within a given situation. ${ }^{413}$ Furthermore, it stated that it shall pay specific attention to crimes that have been traditionally under-prosecuted, such as SGB crimes, the recruitment and use of child soldiers, and attacks against humanitarian and peacekeeping personnel. ${ }^{414}$

The OTP stated that ultimately it will aim to investigate and prosecute all cases that meet the case selection criteria. ${ }^{415}$ However, it will also need to prioritize among the cases. It stated that it will do so through a comparative assessment, considering the case selection criteria along with certain prioritization criteria. ${ }^{416}$ Interestingly enough, these criteria largely relate to the practical feasibility of prosecutions, such as the availability of resources and evidence, the security situation, the prospects of international cooperation, judicial assistance, and securing the arrest or voluntary appearance of the suspect. The OTP noted the difference from the policy paper on preliminary examinations, wherein it had held that for situation selection, practical feasibility was not a relevant factor. ${ }^{417}$

In addition, the OTP stated that it will consider the impact of its activities with regard to opposing parties to a conflict, and to the continued commission of crimes. ${ }^{418}$ While it has repeatedly stated that it shall not pursue an equal distribution of "blame," 119 it will consider the appropriateness of pursuing prosecutions of both sides to a conflict simultaneously or in a sequenced manner. The impact on continued crimes could be a reference to the objective of prevention. However, it also brings to mind the discussion on the potentially detrimental impact of ICC prosecutions on peace processes.

The proposed operational criteria appear to be precisely of the type that have been suggested in literature to fall under the interests of

412. Id. at 13-14. See OTP Strategic Plan 2012-2015, supra note 121, at 14. See also supra Section VI.B.2.b.

413. See 2006 Report on Prosecutorial Strategy, supra note 65, at 5-6.

414. Draft Policy Paper on Case Selection and Prioritization, supra note 324, at 14.

415. Id. at $14-16$.

416. Id. at 15 .

417. Id. at 15 n. 42 .

418. Id. at 16 .

419. See id. at 7; Policy Paper on Preliminary Examinations, supra note 158, at If 66. 
justice criterion. ${ }^{420}$ While maintaining its restrictive policy on the interest of justice, the OTP chooses to consider these factors more freely as part of the discretionary prioritization of cases. ${ }^{421}$ Given the distinction made between selection and prioritization, this means that the factors will not necessarily preclude the selection of a case. Instead, they will guide the order in which cases are pursued. This seems to suggests a reluctance to afford these factors much weight.

\section{Analysis of Strategic Choices}

The following sections will first respond to the following subquestion from the Article's Introduction: What are some strategic choices that the OTP has made with respect to situation and case selection? Three select strategic choices will be presented, related to the process of situation and/or case and selection, that can be gathered from the OTP's policy and practice. Moreover, how these choices relate to some of the objectives of the ICC identified in Section IV above will be discussed. In other words, it is an attempt to answer the overarching question: how do strategic choices of the OTP correspond to the objectives of the ICC?

\section{A. Strategic Choice 1: Presumption for the Interests of Justice}

\section{In Policy}

When searching the OTP's strategy and policy documents for choices on situation and case selection, it is striking that perhaps the most discretionary criterion at the OTP's disposal, the interests of justice under Article 53(1) (c) and (2) (c), is largely downplayed. In the policy papers on the interests of justice and on preliminary examinations, the OTP emphasizes the exceptionality of the criterion. In fact, the Office argues that investigations and prosecutions that fulfill other legal criteria should be presumed to serve the interests of justice. ${ }^{422}$ Moreover, the OTP has expressly ruled out certain considerations, such as the impact on peace processes and practical feasibility, that other commentators have argued are appropriate to consider under the interests of justice. ${ }^{423}$

420. See, e.g., Goldston, supra note 2, at 304-99; Davis. supra note 5, at 182-83; Brubacher, supra note 224 , at $81-82$.

421. Draft Policy Paper on Case Selection and Prioritization, supra note 324, at 11, 15-16.

422. POLICY PAPER ON THE INTERESTS OF JUSTICE, supra. note 216 at 1 ; POLICY PAPER ON Preliminary EXaminations, supra note 158, at $\mathbb{9} 71$.

423. See infra $\mathrm{V}(\mathrm{D})(3)(\mathrm{d})$. 
The presumption for the interests of justice applies both to situation and to case selection. However, when it comes to case selection, it does not necessarily mean that factors such as practical feasibility cannot be considered. As stated earlier, case selection is more explicitly discretionary than situation selection. It is not expected that all cases within a situation that meet the legal criteria will actually be pursued by the OTP. ${ }^{424}$ This is also well-reflected in the Office's strategy and policy documents, notably with the 2006-2012 policy of focused investigations and prosecutions ${ }^{425}$ While the current policy of in depth, open-ended investigations is more ambitious in terms of the number of cases the OTP aims to pursue, it still reflects an understanding that, given the practical restraints, not all viable cases can realistically be selected. Interestingly enough, the recent draft policy paper on case selection suggests case prioritization criteria that relate to the practical feasibility and impact of prosecutions. ${ }^{426}$ Arguably, this affords the factors a more modest place among the criteria guiding the OTP's discretion than if they were considered under the "interests of justice." Prioritizing one case over another does not mean that the OTP is deciding not to prosecute in the latter case. Therefore, at least judging from current PTC practice, prioritization will not become subject to PTC review. ${ }^{427}$

When it comes to situation selection, the OTP's initial position in the 2003 policy paper seemed to be that issues such as the nature and stage of conflict and the prospects of cooperation would need to be considered. ${ }^{428}$ Because situation selection is mainly initiated by others, it is difficult to see how the OTP could consider such factors except via the interests of justice. Using the criterion of the interests of justice would permit the OTP to make a different assessment on the appropriateness of proceeding with an investigation than a referring state, the SC, or a sender of an Article 15 communication. Therefore, with the presumption for the interests of justice, it appears that the Office has somewhat changed its position on situation selection. ${ }^{429}$ Consequently, issues such as practical feasibility and political sensitivity will have less impact on the selection of situations than of cases.

424. See Schabas, Selecting Situations and Cases, supra note 33, at 377.

425. 2006 Report on Prosecutorial Strategy, supra note 65; Prosecutorial Strategy 2009-2012, supra note 121.

426. Draft Policy Paper on Case Selection and Prioritization, supra note 324, at 15 n.42.

427. Situation in the DRC, Decision on Request Pursuant to Rule 103(1), PTC I, supra note 305, II 5 .

428. See generally Policy PaPer on Preliminary Examinations, supra note 158.

429. See Schabas, Selection Situations and Cases, supra note 33, at 380-81. 


\section{In Practice}

To date, the OTP has never based a decision not to investigate or prosecute on the interests of justice and, thus, such a decision has not been under the review of the Court. ${ }^{430}$ When requesting the PTC to authorize investigations, the OTP has not found any reason to make such a negative determination. ${ }^{431}$ While the presumption for the interests of justice has not been expressly referred to, it seems likely that the OTP's practice is reflective of this policy. It might be interesting to consider whether the OTP would have had reason to apply the interests of justice criterion, were it not for its restrictive policy. Due to the lack of express pronouncements by the OTP on the issue, and because there is no real consensus on what the interests of justice would include, such a discussion will largely be speculative. It can be noted, however, that several of the OTP's investigations and prosecutions have both sparked political controversy and caused practical difficulties for the OTP.

A prime example is the investigation in Darfur, Sudan, and in particular the arrest warrant against Sudanese President Omar alBashir. The situation was referred by the SC in 2005, following a U.N. Commission of Inquiry on violations of international humanitarian and human rights law in Darfur. ${ }^{432}$ The OTP decided to open an investigation. ${ }^{433}$ Due to prevailing insecurity, the investigative activities took place outside of Darfur, making the OTP especially dependent on the assistance of states, NGOs, and international organizations. ${ }^{434}$ Eventually, six arrest warrants were issued, including two against the sitting head of state, al-Bashir, for crimes against humanity, war crimes, and genocide. ${ }^{435}$

The arrest warrant for al-Bashir is politically controversial to say the least. The League of Arab States and the African Union (AU) have both

430. deGuzman and Schabas, supra note 7, at 145.

431. See, e.g., Request for Authorization of an Investigation Pursuant to Article 15, ICC/02-11, III 59-60 (June 23, 2011).

432. S.C. Res. 508, II 1 (Mar. 31, 2005).

433. Press Release, Office of the Prosecutor, Int'l Criminal Court, The Prosecutor of the ICC Opens Investigation in Darfur, ICC-OTP-0606-104 (June 6, 2005).

434. See Office of the Prosecutor, Int'l Criminal Court, Second Report of the Prosecutor of the International Criminal Court, Mr. Luis Moreno OCAmpo, to the Security Council PURSUANT TO UNSCR 15934 (Dec. 13, 2005).

435. Prosecutor v. Al Bashir, ICC-02/05-01/09, Warrant of Arrest for Omar Hassan Ahmad Al Bashir, (Mar. 4, 2009); Prosecutor v. Al Bashir, ICC-02/05-01/09, Second Warrant of Arrest for Omar Hassan Ahmad Al Bashir (July 12, 2010). 
issued statements in support of the President, rejecting the arrest warrant. ${ }^{436}$ The Assembly of the AU argued that the indictment had a detrimental effect on the peace process in Sudan. ${ }^{437}$ It later issued a statement urging the OTP to amend its prosecutorial policy to include factors concerning the promotion of peace. ${ }^{438}$ In other words, the AU objected to the OTP's statement in its policy paper on the interests of justice, holding that it would not consider such factors as promoting peace. The AU Assembly also recommended an amendment to Article 16 of the Statute in order to allow the U.N. General Assembly, and not just the SC, to defer investigations and prosecutions at the ICC. ${ }^{439}$ In other words, the AU's position appeared to be skeptical, at best, to the notion of wide prosecutorial discretion at the ICC.

Due to its strong objections to the indictment of al-Bashir, the AU has recommended its member states not to cooperate with the ICC in the arrest and surrender of the suspect, pursuant to Article 98 of the Statute. ${ }^{440}$ Accordingly, al-Bashir has since been able to travel to several countries (mainly in the Middle East and Africa), including ICC member states, such as the DRC and South Africa, without being arrested. ${ }^{441}$ The four other indicted individuals in the Situation in Darfur also remain at large. In briefings to the SC on the progress of activities, the Prosecutor has expressed frustration over this fact, and requested that the SC make efforts to urge more state cooperation with the ICC. ${ }^{442}$ The same can be said for the other situation referred by the SC, Libya, where the OTP has not been able to secure the arrest of

436. Al Jazeera, Arab Leaders Snub Al-Bashir Warrant, AL JAzEERA, (Mar. 31, 2009), http:/ /www. aljazeera.com/news/middleeast/2009/03/2009330175846714662.html; Dec. 245 (XIII) Rev.1, Decision on the Meeting of African State Parties to the Rome Statute of the International Criminal Court (ICC), Assembly of the African Union, (July 3, 2009).

437. See Dec. 245 (XIII) Rev.1, supra note 436.

438. Dec. 270 (XIV), Decision on the Report of the Second Meeting of States Parties to the Rome Statute on the International Criminal Court (ICC), Assembly of the African Union, (Feb. 2, 2010).

439. Id.

440. See Dec. 245 (XIII) Rev.1, supra note 436.

441. Office of the Prosecutor of the International Criminal Court, Twenty-Second Rep. of the Prosecutor of the International Criminal Court to the U.N. Security Council Pursuant to the UNSCR 1593 (2005), ICC OTP, II 7 (Dec. 15, 2015).

442. Fatou Bensouda (Prosecutor of the International Criminal Court), Twenty-First Rep., Statement to the United Nations Security Council on the Situation in Darfur, Pursuant to UNSCR 1593 (2005), (June 29, 2015). 
indicted suspect Saif Al-Islam Gadaffi. ${ }^{443}$

The lack of cooperation from states has thus had a considerable impact on the practical feasibility of investigation and prosecution in both situations referred by the SC. This has also been the case with the proprio motu investigation in Kenya, and the indictment of Kenyan President Uhuru Kenyatta and his deputy William Samoei Ruto. ${ }^{444}$ Like in the case of al-Bashir, the AU has protested the indictments of a sitting head of state. The Prosecutor eventually found it necessary to withdraw the charges against Kenyatta due to the difficulties of securing enough evidence, which was partly due to lack of cooperation from the Kenyan government. ${ }^{445}$

The fact that most ICC investigations concern the African continent has also led to the accusation from African leaders and other commentators that the OTP is biased against Africa. ${ }^{446}$ The question of a potentially detrimental impact of ICC intervention on peace processes has come up notably in regard to the Situation in Uganda. Views differ as to whether the arrest warrants issued for members of rebel group the Lord's Resistance Army (LRA) were detrimental or helpful to ongoing peace negotiations between the LRA and the Ugandan government. ${ }^{447}$ Furthermore, the issue of practical feasibility has been brought up by the OTP itself with regard to the preliminary examination of the Situation in Afghanistan, stating that its activities have been hampered by

443. Office of the Prosecutor of the International Criminal Court, Tenth Rep. of the Prosecutor of the International Criminal Court to the United Nations Security Council pursuant to UNSCR 1970 (2011), ICC OTP, (Oct. 26, 2015), II 3-5.

444. See Shane Hickey, African Union Says ICC Should Not Prosecute Sitting Leaders, THE GuARDIAN, (Oct. 12, 2013), http://www.theguardian.com/world/2013/oct/12/african-union-icckenyan-president. The OTP later decided to withdraw the arrest warrant against Kenyatta due to insufficient evidence. See Prosecutor v. Uhuru Muigai Kenyatta, ICC-01/09-02/11, Decision on the Withdrawal of Charges Against Mr. Kenyatta, Trial Chamber V, ICC, III 4, 10 (Mar. 13, 2015), https://www.icc-cpi.int/Pages/record.aspx?docNo=ICC-01/09-02/11-1.

445. Fatou Bensouda (Prosecutor of the International Criminal Court), Statement of the Prosecutor of the International Criminal Court, on the Withdrawal of Charges Against Mr. Uhuru Muigai Kenyatta, (Dec. 5, 2014).

446. See Alette Smeulers et al., The Selection of Situations by the ICC: An Empirically Based Evaluation of the OTP's Performance, 15 InT'L CRIM. L. REv. 1, 3-4 (2015); Anthony Kariuki, War Crimes and Punishment: Why is the ICC Targeting Africa, Brown Pol. Rev. (Mar. 12 2015), http://www. brownpoliticalreview.org/2015/03/war-crimes-and-punishment-why-is-the-icc-targeting-africa.

447. See Patrick Corrigan, Why the ICC Must Stop Impeding the Juba Process, DAILY MONITOR, (July 27, 2007), https://www.globalpolicy.org/component/content/Article/164/28641.html; Ernest Harsch, Seeking Peace With Justice in Uganda, AfRICA Renewal, (Jan. 2006), http://www.un.org/ africarenewal/magazine/january-2006/seeking-peace-justice-uganda. 
limited state cooperation and by security constraints. ${ }^{448}$ However, the OTP has not explicitly argued that such difficulties speak against launching a full investigation in Afghanistan. ${ }^{449}$

Once again, it is not argued that the OTP has had reason to apply the interests of justice criterion in any particular situation or case. The examples above are simply meant to show that issues such as political appropriateness, impact on peace processes, and practical feasibility have been raised in regard to several ICC investigations and prosecutions. Most of these issues are, of course, inherently political and controversial. For example, it is perhaps unsurprising that indicted leaders such as Kenyatta and al-Bashir would use their political influence to accuse the Court of political bias. ${ }^{450}$ At the same time, it is clear that a reluctance to cooperate, or even open opposition, from actors such as the AU has a detrimental effect on the OTP's ability to carry out investigations and prosecutions, and possibly on the general perception of the Court within the international community. ${ }^{451}$

The examples provided suggest that much of the controversy surrounding the OTP's discretion has concerned the selection of defendants, or, in other words, cases. This could possibly be explained by the high political profile of some of the selected defendants, and perhaps by the fact that prosecution appears more aggressive in character than the opening of an investigation. However, the alleged unfair focus on situations in Africa has also been at the forefront of criticism by, for example, the AU. In addition, the practical difficulties in conducting investigations and preliminary examinations in situations such as Darfur and Afghanistan have not been limited to specific cases. It is therefore clear that the considerations often associated with the interests of justice may become relevant both for situation and case selection.

\section{Analysis}

\section{a. A Duty to Investigate and Prosecute}

When explaining the presumption for the interests of justice, the OTP specifically invoked the objectives of ending impunity, preventing

448. The Office of the Prosecutor of the International Criminal Court, Report on Preliminary Examination Activities II If 36-38 (2012).

449. Id.

450. See Goldston, supra note 2, at 386 .

451. Id. at $399-400$. 
crimes, and improving respect for international law. ${ }^{452}$ The reasoning is rather self-evident: assuming that these objectives will be furthered by criminal prosecutions, they will in most cases speak against applying the interests of justice criterion. Furthermore, the OTP referred to a consistent trend in international law establishing a duty for states to investigate and prosecute core international crimes. ${ }^{453}$ The OTP also stated that, quite simply, its own role is to investigate and prosecute core international crimes. ${ }^{454}$ Put together, these two statements suggest a corresponding duty for the OTP to investigate and prosecute crimes where states fail to act. The underlying rationale for this reasoning is the principle of complementarity. The arguments seem to reflect a vision of a sort of worldwide justice system where all perpetrators of core international crimes will be held accountable, either by national courts or by the ICC-the ultimate aspiration being an end to impunity. The ICC's ability to perform its duty will of course be limited by factors outside of the OTP's control, such as the fact that not all states accept the Court's jurisdiction. However, it might be argued that in order to do its part, the OTP should consistently choose to investigate and prosecute to the full extent of its mandate. Thus, discretionary decisions to decline investigating or prosecuting, for example by applying the interests of justice criterion, should be kept to a minimum.

This line of thought most directly brings to mind the objective of ending impunity. But a comprehensive system of international justice would, if achieved, be in line with nearly all the ICC's objectives. By significantly increasing the risk of prosecution for core international crimes, it is likely that a higher deterrent effect would be attained, respect for human rights and humanitarian law would increase, the contribution of criminal proceedings to building historical records would be greater, and more victims would benefit from redress.

However, given the current capacity of both the ICC and national justice systems, it seems equally evident that such a system will not be achieved in the foreseeable future. Even considering the principle of complementarity, a duty for the ICC to comprehensively fill in the blanks where states fail will most likely be insurmountable. ${ }^{455}$ As explained earlier, a realistic view on the Court's capacity is reflected in OTP strategy and policy on case selection, recognizing that not all

452. See generally Policy Paper on the Interests of Justice, supra note 216.

453. Id. at 3 .

454. See generally id.

455. Policy Paper on Preliminary Examinations, supra note 158, I 9. 
viable cases can be pursued. ${ }^{456}$ While the OTP has not expressed an equally discretionary approach to situation selection, its ability to open investigations is practically constrained by jurisdictional limits and by the influence of other actors, notably the SC and the PTC. Both situation selection and case selection will, therefore, most likely fall short of the ambitions of creating a comprehensive international justice system.

When it comes to the ICC's objectives, the selection of a limited number of situations and cases most easily aligns with the pedagogical objective of improving respect for international law. In order to attain this objective, at least in the version advanced by Damaška, it is not the quantity of investigations and prosecutions that matter. Instead, it is their quality in setting normative and pedagogical examples. ${ }^{457}$ Therefore, the key question for the OTP is how to put its limited time and resources to their most effective use. In other words, the question is not if the OTP should select a limited number or situations and cases, but how, or based on what criteria.

Should the OTP, for instance, focus on the situations and cases that are most likely to end in convictions, or that are most likely to have a positive effect on processes of peace and reconciliation? Should it, for pragmatic reasons, avoid investigations and prosecutions that are politically controversial or, conversely, demonstrate that important principles such as the responsibility of political leaders must be upheld despite political controversy? Arguably, while upholding an idealistic vision of a universal system of justice may be inspiring and exemplary, it does not provide enough guidance for the actual choices of the OTP. Therefore, there must arguably be some additional reasons for the OTP's choice to, as a general rule, not make use of the interests of justice criterion.

\section{b. An Apolitical Prosecutor}

As explained earlier, one of the most commonly proposed functions for the interests of justice criterion is to give the Prosecutor enough discretion to avoid undesirable political ramifications of investigations and prosecutions. Both the former and the current Prosecutor have repeatedly discarded the idea of involving "politics" in their decision-

456. Paper on SOMe POlicy issues Before the Office of the Prosecutor, supra note 62; 2006 Report on Prosecutorial Strategy, supra note 65, at 5-6; Draft Policy Paper on Case Selection AND PRIORITIZATION, supra note 324, at 14-16.

457. See Damaška, supra note 67, 345-47. 
making. ${ }^{458}$ The presumption for the interests of justice seems to follow in that same vein. By adhering to such a principle, the OTP perhaps wishes to avoid and refute accusations of political bias that may affect its perceived legitimacy. The rationale could be described as legalistic, representing an ideal of justice as blind, uncompromising, and unyielding.

The OTP seems to reject political considerations categorically. However, as Alexander Greenawalt has pointed out, the word "political" is imprecise. ${ }^{459}$ It could be argued that certain considerations fall more squarely than others into the political sphere, being clearly inappropriate for a legal decision-maker to consider. An example of this provided by Greenawalt would be the existence of diplomatic or economic ties between a government involved in genocide and a government that sits on the SC. ${ }^{460}$ However, other considerations that can be described as political or extralegal may nonetheless have a more legitimate claim to be included in prosecutorial decision making. ${ }^{461}$ An example of this might be the practical feasibility of investigations depending on the security situation on the ground, or the impact on potentially fragile political processes such as peace negotiations or elections.

The OTP's wish to avoid political calculations in its decision-making could also be related to the strategic choice to target high-ranking leaders. The OTP seemingly wished to stress that no perpetrator should be able to avoid responsibility through political maneuvering. As the $A l$ Bashir and Kenyatta cases demonstrate, obstruction by political leaders may be difficult to avoid in practice. However, even if indicted politicians such as the Sudanese and Kenyan presidents are successful in opposing the OTP, that does not necessarily mean that the OTP should yield to such opposition. It could be argued that by persisting with these cases, the OTP promotes an uncompromising form of justice, setting a pedagogical example and challenging impunity even for the most powerful. Conversely, it could be argued that the OTP should prioritize situations and cases with a higher probability of success, thereby demonstrating a higher degree of effectiveness and viability.

458. See, e.g., Luis Moreno-Ocampo, Prosecutor, Int'l Crim. Ct., Keynote Address at Council on Foreign Relations, Washington, D.C., (Feb. 4, 2010), 6; Fatou Bensouda, Prosecutor Elect, Int'l Crim. Ct., Introductory remarks: Lessons from Africa, International Conference: 10 years review of the ICC: Justice for All? (Feb. 15, 2012), 5.

459. Greenawalt, supra note 3 , at 613.

460. Id.

461. Id. 
This study will come back more specifically to the issue of selecting high-level perpetrators. ${ }^{462}$ However, the same type of dilemma applies to other potential considerations under the interests of justice, most notably those who relate to practical feasibility. When investigations and prosecutions are hampered by security concerns or by a lack of state cooperation, the OTP directing its attention and limited resources elsewhere may be more beneficial to objectives that build on the actual completion of trials, such as ending impunity, providing redress for victims, and preventing crimes. ${ }^{463}$ From the perspective of improving the respect for norms, it might also be argued that fostering political and public support for international justice will be more difficult if the OTP alienates actors such as the AU. ${ }^{464}$ A counterargument, based on the same objective, is that persisting in spite of difficulties and political opposition can have an important pedagogical function.

Furthermore, from the perspective of victims, it may be important to see that decisions are not based on grounds that can be perceived as arbitrary or unfair. To put it bluntly, why should the victims in Darfur be ignored by the ICC because President al-Bashir has been successful in avoiding justice? In fact, the OTP has often been motivated by a wish to persist in spite of practical challenges with a commitment to the victims' right to redress. ${ }^{465}$

One final point should be made about the OTP's choice to reject political considerations in the selection of situations. ${ }^{466}$ As stated earlier, the OTP appears to uphold such a policy more strictly when it comes to situations. But, paradoxically enough, it could be argued that

462. See infra Section VII.C.

463. See Gallón, supra note 56, at 97 (stating that the level of deterrence is directly proportional to accountability: the more the violators are stopped and held accountable-the higher the deterrent effect).

464. See Greenawalt, supra note 3, at 663.

465. Compare Fatou Bensouda (Prosecutor of the International Criminal Court), Twenty-first Rep., Statement to the United Nations Security Council on the Situation in Darfur,

Pursuant to UNSCR 1593 (2005), (June 29, 2015) ("Victims of Darfur have been let down for far too long."), with Statement of the Prosecutor of the International Criminal Court, on the withdrawal of charges against Mr. Uhuru Muigai Kenyatta, Fatou Bensouda (Prosecutor of the International Criminal Court), Statement of the Prosecutor of the International Criminal Court, on the withdrawal of charges against Mr. Uhuru Muigai Kenyatta, (Dec. 5, 2014) ("Ultimately, the hurdles we have encountered in attempting to secure the cooperation required for this investigation have in large part, collectively and cumulatively, delayed and frustrated the course of justice for the victims in this case.").

466. See Smeulers et al., supra note 446, at 3. 
this strengthens the political dimensions of situation selection by leaving it more in the hands of political actors such as states and the SC. In fact, through the presumption of the interests of justice, the OTP will in most cases accept these actors' assessment of the political appropriateness of ICC intervention. However, a main point of giving the Prosecutor an unprecedentedly high degree of influence over the selection of situations and cases selection was to give this process a judicial rather than political character. ${ }^{467}$ The granting of proprio motu powers was, of course, the clearest demonstration of this aspiration. ${ }^{468}$ Arguably, the fact that the OTP must assess and make a decision on whether or not to proceed even following state and SC referrals is also very significant.

Is the greater influence of states and the $\mathrm{SC}$ over situation selection an undesirable effect of the OTP's policy on the interests of justice, or can it be defended? On the one hand, it seems that most arguments against the so-called politicization of justice can be raised here. ${ }^{469}$ While the Prosecutor is to act as an objective officer of justice, ${ }^{470}$ the interests of states go far beyond the promotion of international justice. They are therefore arguably more likely to have inappropriate political motives for the selection of situations, such as a desire to get rid of a political rival or to protect a political ally. ${ }^{471}$ Considering the objective of strengthening respect for international law, there is arguably an important symbolism in a judicial actor such as the OTP acting as a check on the selection of situations by states and the SC.

Conversely, it could be argued that the presumption for the interests of justice puts political judgment on situation selection precisely where it belongs-in the hands of political actors. Such a reasoning has been expressed by the OTP with regard to the SC and the consideration of "the interests of peace." ${ }^{472}$ This brings us to the following section of this analysis, looking more closely at the question of peace vs. justice.

\section{c. The Interests of Justice vs. the Interests of Peace}

An especially interesting aspect of the OTP's restrictive policy on the interests of justice is its unwillingness to consider "the interests of

467. See id.

468. See Greenawalt, supra note 3, at 661 .

469. See id. at 613 .

470. Claus Kress, The Procedural Law of the International Criminal Court in Outline: Anatomy of a Unique Compromise, 1(3) J. Int'l Crim. Just., 603, 608 (2003).

471. See Greenawalt, supra note 3 , at 613 .

472. Policy PAPER On the INTERESTs of Justice, supra note 216, at 8-9. 
peace." ${ }^{473}$ If restoring international peace and security is accepted as an objective of the ICC, this strategy could of course be challenged. It could be argued that, instead, the OTP should use every tool at its disposal to contribute to this objective. A potential detrimental effect of its activities on peace processes could hardly be accepted.

However, the OTP's approach could perhaps be reconciled with an objective of promoting peace. In fact, the OTP argued that justice and peace are not necessarily conflicting interests, but interrelated and interdependent. ${ }^{474}$ The potential contribution of the ICC to the promotion of peace can be linked to other objectives. By ending impunity, providing redress to victims, and contributing to memorialization, the Court might also contribute to sustainable peace. Moreover, by improving respect for international law, the ICC might challenge a culture of impunity that hampers peace and reconciliation. Therefore, it could be argued that the best thing that the ICC could do for the cause of peace would be to underline its role as a judicial institution, basing its decision on strictly legal criteria rather than on fluctuating factors such as the state of peace negotiations.

However, while it is possible for criminal prosecutions to have a positive effect on peace efforts, the interdependence of justice and peace arguably goes both ways. Conflicts cause problems for the administering of justice, including for the ICC, by creating political, logistical and security-related hurdles. ${ }^{475}$ For this reason, it has been argued that in some cases, justice must be preceded by peace ${ }^{476}$ With such a view, it is the timing of ICC operations rather than their appropriateness per se that is questioned. As mentioned earlier, others argue that alternative forms of justice are more suitable than criminal prosecutions in certain situations. ${ }^{477}$ This reflects a more relativist view on the norms of international criminal law, as compared to the more universalist view that the OTP expressed. ${ }^{478}$ Depending on how it is framed, the objective of improving respect for international law could

473. Id.

474. Id.

475. See, e.g., Second Report of the Prosecutor of the International Criminal Court, Mr. Luis Moreno Ocampo, to the Security Council Pursuant to UnSCR 1593 (2005), supra note 434 , at 4 .

476. See Greenawalt, supra note 3, at 641-47.

477. See, e.g., Mbeki \& Mamdani, supra note 95; Vinjamuri, supra note 95, at 12-29.

478. The discussion on universalism vs. cultural relativism is prevalent in human rights discourse. See, e.g., Jack Donnelly, Cultural Relativism and Universal Human Rights, 6 Human Rights Quarterly 400 (1984). The Vienna Declaration, adopted by the World Conference on Human Rights in Vienna on 25 June 1993, established in its first operative paragraph that "the universal 
therefore be invoked in favor of either view.

Another way of aligning the ICCs approach with an objective of promoting peace is the OTP's argument on the institutional division of powers between itself and the SC. ${ }^{479}$ It can convincingly be argued that, due to its primary responsibility within the U.N. system for the maintenance of international peace and security, the SC is better placed than the OTP for making determinations on the interests of peace. Jens David Ohlin even argues that, as a matter of international law, the OTP should not be able to invoke the interests of justice in order to decline investigating a situation referred by the $\mathrm{SC} .{ }^{480} \mathrm{In}$ his opinion, doing so would be contrary to the binding Chapter VII powers of the SC, combined with the legal primacy of the U.N. Charter over the Statute. ${ }^{481}$ In a similar vein, Greenawalt argues that the OTP is ill-equipped to determine the appropriateness of criminal prosecutions in periods of post-conflict transition, and that a potential solution would be to consult the more competent SC. ${ }^{482}$

With such a view, it could be argued the ICC, like the ad hoc tribunals, can contribute to peace and security mainly as an instrument of the SC. With the powers of referral and deferral, the SC has the activation and deactivation of the ICC as tools for handling situations of conflict. ${ }^{483}$ However, such a limited role for the ICC in contributing to peace is difficult to reconcile with other aspects of the Statute, such as the independence of the OTP, its proprio motu powers and, perhaps most notably, its power to decline opening an investigation even following a SC referral. ${ }^{484}$

\section{d. Conclusions: Focusing on "What A Court Does Best"}

Especially considering the imprecision of the interests of justice criterion, discussing a policy not to apply will necessarily be somewhat speculative. However, it raises important questions on the valid uses of prosecutorial discretion. With the presumption for the interests of justice, the OTP appears to have adopted a legalistic or even idealistic

nature of [these] rights and freedoms is beyond question." See Vienna Declaration and Programme of Action art. 1, June 25, 1993, 32 I.L.M. 1661 (1993).

479. Jens David Ohlin, Peace, Security and Prosecutorial Discretion, in The Emerging Practice of THE International Criminal Court 185, 187 (Carsten Stahn \& Göran Sluiter eds., 2009).

480. See generally id.

481. See U.N. Charter arts. 25, 103.

482. Greenawalt, supra note 3, at 650-51, 664-69.

483. See supra Section V.B. and Section V.C.6.

484. But see Ohlin, supra note 479, at 189. 
approach to its own mandate, as opposed to the more pragmatic approach advocated by some commentators. The core question is two-fold. Firstly, should pragmatic or extralegal considerations at all affect the selection of situations and cases? Secondly, if such considerations are acceptable, who should consider them? Should it be the OTP, or another actor, such as the SC, a state, or perhaps the PTC?

At the outset, a distinction should likely be made between factors that are clearly unsuitable to consider in legal decision-making, and factors that could be defended from a pragmatic point of view. The latter category might include practical feasibility, the prospect of state cooperation and the potential impact on peace processes. From the draft policy paper on case selection, it appears that the OTP may consider such factors, though only to a limited extent, and not necessarily by invoking the interests of justice. ${ }^{485}$ However, precisely by not linking such considerations to this legal criterion, the OTP in fact remains in charge of them. In fact, the final arbiter of the interests of justice is not the OTP, but the PTC. While judicial review of prosecutorial discretion may be motivated in principle, the types of factors discussed here are arguably better considered by a prosecutor than by judges. They have to do with the realities of conducting investigations under complex and often difficult circumstances—realities more familiar to the OTP than the PTC. Furthermore, if it is inappropriate for the Prosecutor to make determinations with political undertones, would it not be even more inappropriate for a Chamber of the Court? ${ }^{486}$ Arguably, the importance of a strictly judicial and apolitical role is even greater for judges than for prosecutors, as the latter can be said to have more of an executive function.

However, in situation selection, the OTP seems to hold that there is no place for pragmatic or extralegal considerations. As a consequence, such considerations are left in the hands of more explicitly political actors such as the SC and states. Arguably, these actors are more competent in certain respects. However, they may also be more likely to consider politics in an inappropriate or biased sense. In the worst case, this may reflect negatively on the ICC. As Louise Arbour put it: "The greatest threat, in my view, to the legitimacy of the permanent Court, would be the credible suggestion of political manipulation of the Office of the Prosecutor, or of the Court itself, for political

485. Draft Policy Paper on Case Selection and Prioritization, supra note 324, at 15 n.42, 16.

486. See Greenawalt, supra note 3, at 659-60; Olásolo, supra note 6, at 105. 
expediency." 487

How the presumption for the interests of justice relates to the ICC's objectives is open for discussion. The OTP's own explanation most clearly brings to mind ending impunity, but also the closely related objectives of preventing crimes, improving respect for international law, and providing redress to victims. It can be argued that declining to investigate or prosecute for reasons that can be seen as extralegal runs counter to these objectives. Alternatively, it could be held that in order to further them in the long term, the OTP should pay close attention to its practical impact and perceived legitimacy. With this view, ignoring pragmatic factors would be less than strategic.

In a similar way, the most obvious interpretation of the strategic choice is that it will not further the objective of promoting peace. However, with a slightly different view on the relationship between justice and peace, it can be argued that the OTP should maintain a strictly judicial role and leave as much leeway as possible to actors like the SC. Still, this in fact means that other objectives, namely those listed in the previous paragraph, are prioritized over the promotion of peace and security. This could perhaps be explained by the fact that the former objectives are more traditionally legal in character. Perhaps promoting peace should rather be seen as a long-term and overarching political goal of the ICC's founders, for which the ICC is no more than a piece of a much bigger puzzle. To put it very simply, a court should do what a court does best.

\section{B. Strategic Choice 2: Relative Gravity in Situation Selection}

\section{In Policy}

In the OTP's strategy and policy documents, the gravity criterion in Article 53(1)(b) and (2)(b) in conjunction with Article 17(1)(d) stands in stark contrast with the interests of justice. Instead of being downplayed, gravity is emphasized as an important consideration for both situation and case selection. ${ }^{488}$ In the policy paper on the interests of justice, the following is said about the relationship between gravity and the interests of justice:

487. Arbour, supra note 33, at 213.

488. See Policy Paper on Preliminary Examinations, supra note 158, at 15-16; Policy Paper on the Interests of Justice, supra note 216, at 4-7; 2006 Report on Prosecutorial Strategy, supra note 65 , at 5; Prosecutorial Strategy 2009-2012, supra note 121, at 5-6. 
Before considering whether there are substantial reasons to believe that it is not in the interests of justice to initiate an investigation, the Prosecutor will necessarily have already come to a positive view on admissibility, including that the case is of sufficient gravity to justify further action. These reflections demonstrate both the central importance of the element of gravity of the crime, as well as the strong presumption in favour of initiating an investigation where the threshold of sufficient gravity is met. ${ }^{489}$

The quote suggests that gravity, unlike the interests of justice, is a useful criterion for situation selection. But besides placing emphasis on gravity, the OTP does not really convey a specific strategic choice. What does the "central importance" of gravity actually mean to the practice of situation selection? Has it made the OTP scrutinize SC referrals, state referrals and Article 15 communications in any particular way?

\section{In Practice}

The OTP has twice declined to open investigations due to insufficient gravity. The first time was in 2006, in response to Article 15 communications alleging crimes committed by British troops in Iraq. Because the United Kingdom is a state party to the Statute, the ICC could exercise jurisdiction over such cases. In a published letter to the senders of the communications, Prosecutor Moreno Ocampo explained his decision not to open an investigation. ${ }^{490}$

After analyzing the information, the OTP found a reasonable basis to believe that a number of war crimes, in the form of willful killings and inhuman treatment, had been committed. ${ }^{491}$ The OTP went on to assess the admissibility of the situation under Articles 53(1)(b) and 17 of the Statute. Beginning with gravity, it stated that the criterion was necessary in order for the OTP to select among the many situations it could potentially investigate. ${ }^{492}$ Firstly, the OTP cited the definition of war crimes in Article 8(1), stating that "the Court shall have jurisdiction in respect of war crimes in particular when committed as part of a plan or policy or as part of a large-scale commission of crimes." ${ }^{493}$ It argued

489. Policy Paper on the Interests of Justice, supra note 216, at 5.

490. OTP Response to Communications Received Concerning Iraq, supra note 214.

491. Id. at 8 .

492. Id.

493. Id. 
that, while these factors were not strict requirements, they provided guidance as to which situations the OTP should focus on, and that these factors did not appear applicable in the present situation. ${ }^{494}$

Secondly, turning to the more general notion of gravity under Article 53(1) (b), the OTP found the number of victims to be a key factor. ${ }^{495}$ It estimated the number of potential victims in the situation to somewhere between four and twenty persons, and compared this with other situations under investigation at the time in Uganda, DRC, and Darfur. ${ }^{496}$ The OTP held that each of those situations involved "thousands of willful killings as well as intentional and large-scale sexual violence and abductions" and that, altogether, they had resulted in the displacement of more than five million people. ${ }^{497}$ In conclusion, the OTP found that the Iraq situation did not meet the threshold of sufficient gravity. Therefore, it did not find it necessary to consider complementarity, and decided to close the preliminary examination. ${ }^{498}$

The Iraq decision demonstrates a view on gravity as a parameter for the prioritization of situations. In other words, the gravity of one situation is seen as relative to the other situations that the OTP is, or perhaps could be, investigating. Because the OTP admits that the aggravating factors in Article 8(1) are not strict requirements, it appears that the comparison with other situations was the determining factor. But what exactly was the OTP comparing? On the one hand, the number of victims in potential cases within the Situation in Iraq, and on the other hand, the total number of victims of the conflicts in Uganda, DRC, and Darfur, both separately and taken together. As Schabas has pointed out, this comparison does not seem entirely fair. ${ }^{499}$

Apparently, what the OTP was comparing was the potential cases that could arise from the situations. In the Situation in Iraq, the ICC's limited jurisdiction thus leads to a limited number of victims, whereas in the other situations, potential cases could theoretically involve a large number, or even all victims of the conflicts. However, practically speaking, prosecution will always be selective. The OTP has itself stated

494. Id.

495. Id. at 8-9.

496. Id. at 9 .

497. Id.

498. Id.

499. See William A. Schabas, Prosecutorial Discretion and Gravity, in The EMERging Practice of the International Criminal Court 229, 245 [hereinafter Schabas, Gravity]; William A. Schabas, Prosecutorial Discretion v. Judicial Activism, 6 J. InT'L CRIM. Just. 731, 739-41 (2008) [hereinafter Schabas, Discretion]; Schabas, Victor's Justice, supra note 3, at 546. 
that case selection should be representative of "the main types of victimization," ${ }^{500}$ rather than concern all victims of ICC crimes within each situation. At the time of the decision on Iraq, the OTP had yet to bring its first charges. When it did so shortly afterwards, in the Lubanga case, the charges were limited to the war crimes of conscription, enlisting, and using children for participation in hostilities. ${ }^{501}$ In other words, the charges did not involve any of the crimes-willful killings, sexual violence or abductions - which the OTP had essentially stated made the DRC situation graver than the Situation in Iraq. ${ }^{502}$ To date, five to six cases have arisen in each of the situations in Uganda, DRC, and Darfur. ${ }^{503}$ Therefore, as Schabas argues, in terms of magnitude and number of victims, it would have seemed more adequate to compare either the conflict in Iraq as a whole with the African conflicts, or the number of cases that might realistically be selected in each of the situations. $^{504}$

The seemingly questionable logic of the OTP's reasoning has led to some speculation as to its actual motives. ${ }^{505}$ Notably, Schabas suggests that there might have been hidden motives for the OTP's reluctance to get involved with such a politically charged situation as the war in Iraq. ${ }^{506}$ He even holds that the reference to gravity appears as a "a contrived attempt to make the determinations look objective and judicial." ${ }^{507}$ There are not enough grounds to delve further into such speculations. However, suspicions of double standards or ulterior motives do not reflect well on the OTP's impartiality and legitimacy.

In May 2014, Prosecutor Bensouda announced that the preliminary examination of the Situation in Iraq would be reopened. ${ }^{508}$ The deci-

500. 2006 Report on Prosecutorial Strategy, supra note 65, at 5-6; see also Draft Policy Paper on Case Selection and Prioritization, supra note 324, at 14.

501. See Prosecutor v. Dyilo, ICC-01/04-01/06, Warrant of Arrest (Feb. 10, 2006), https://www. icc-cpi.int/CourtRecords/CR2006_02234.pdf; Prosecutor v. Dyilo, ICC-01/04-01/06, Decision on the Confirmation of Charges, I 39 (Jan. 29, 2007). It can be noted that the limited range of charges against Lubanga was the main reason for the Women's Initiative motion discussed supra Section V.D.4.b.

502. See Schabas, Gravity, supra note 499, at 245.

503. See id. at 231-33.

504. Schabas, Discretion, supra note 499, at 747-48.

505. See Ohlin, supra note 479, at 200.

506. Schabas, Victor's Justice, supra note 3, at 548-49. See also Greenawalt, supra note 3, at 641 .

507. Schabas, Victor's Justice, supra note 3, at 549

508. Press Release, Int'l Crim. Court Office of the Prosecutor, Prosecutor of the International Criminal Court, Fatou Bensouda, Re-opens the Preliminary Examination of the Situation in Iraq (May 13, 2014), https://www.icc-cpi.int//Pages/item.aspx? name=otp-statement-iraq-13-052014. 
sion was based on an Article 15 communication containing new information, in particular alleging a higher number of cases of ill treatment of detainees, as well as cases of killings of civilians. ${ }^{509}$ In its 2015 report on preliminary examination activities, the OTP reported that, after additional communications, the total number of alleged cases now exceeded 1,000-including the crimes of rape, sexual violence, and denial of a fair trial. ${ }^{510}$

The preliminary examination of the Situation in Iraq is currently in its initial phase, where the OTP is considering subject-matter jurisdiction. ${ }^{511}$ Therefore, the issue of gravity has not yet been considered. Though it remains to be seen, the considerably higher number of victims according to the new communications can likely lead to a different conclusion on gravity than in 2006, at least if the quantitative factor is again considered as key.

The second situation that the OTP has declined to investigate due to insufficient gravity was referred by the Union of Comoros. ${ }^{512}$ It concerned crimes allegedly committed by Israeli forces during a 2010 interception of a humanitarian aid flotilla bound for the Gaza strip. The OTP published a so called "Article 53(1)" Report, explaining the assessments of the preliminary examination. ${ }^{513}$ Three out of the eight vessels in the flotilla were registered in state parties to the Statute, meaning that the ICC had jurisdiction over crimes committed aboard those vessels. ${ }^{514}$ The OTP further found a reasonable basis to believe that war crimes, in the forms of willful killings, outrages upon personal dignity, and willful causing of injury to body or health, had been committed on board of the Comorian-registered vessel, the Mari Marvara. ${ }^{515}$ However, even if the OTP reasonably believed that war crimes had been committed, it would not be sufficient for the OTP to proceed towards opening a formal investigation.

509. See Office of the Prosecutor, Int'l Criminal Court, Report on Preliminary EXAMINATION ACTIVITIES 2014 II $12-13$ (2014).

510. See Report on Preliminary Examination Activities (2015), supra note 148, at II If 33-38.

511. Id. at II 39-40.

512. See Press Release, Int'l Crim. Court Office of the Prosecutor, Statement of the Prosecutor of the International Criminal Court, Fatou Bensouda, on Concluding the Preliminary Examination of the Situation Referred by the Union of Comoros: "Rome Statute Legal Requirements Have Not Been Met” (Nov. 6 2014), https://www.icc-cpi.int/Pages/item.aspx?name= otp-statement-06-11-2014.

513. Int'l Crim. Court Office of the Prosecutor Situation on Registered Vessels of Comoros, Greece and Cambodia: Article 53(1) Report, (Nov. 6, 2014) [hereinafter Comoros Article 53(1) RePORT].

514. Id. at 13-14.

515. Id. at 54 . 
Moving on to the issue of admissibility, the OTP again began with the gravity criterion. Some general principles for the assessment were reiterated: that both the gravity of the crimes and the level of responsibility of alleged perpetrators would be assessed; that the assessment would be both qualitative and quantitative in nature; and that factors to guide the assessment would include the scale, nature, manner of commission and impact of crimes. ${ }^{516}$ In comparison with the 2006 decision on Iraq, it is clear that the interpretation of gravity has evolved and been guided by the emerging practice of the PTCs when authorizing proprio motu investigations. ${ }^{517}$

Like in the Iraq decision, the OTP also brought up the definition of war crimes in Article 8(1) of the Statute, and its referral to the existence of a plan or policy and to the large-scale nature of crimes. ${ }^{518}$ The OTP stated that, because the situation was limited to the "flotilla incident," the wider context of the Israel-Palestine conflict could not be taken into account when assessing gravity. ${ }^{519}$ For this reason, the Office did not find the aggravating factors in Article 8(1) to be applicable. ${ }^{520}$

Also in parallel to the Iraq decision, the OTP considered the scale of the alleged crimes to be relatively limited compared to other "cases" under investigation. ${ }^{521}$ However, it stated that such a quantitative factor could be countervailed by qualitative circumstances, such as a particularly cruel manner of commission or an especially significant impact of crimes. ${ }^{522}$ Furthermore, it stated that it was possible for a limited incident involving a small number of victims to meet the gravity threshold. It referred specifically to the Abu Garda case in the Situation in Darfur, regarding an attack against the African Union peacekeeping mission in Sudan (AMIS) ${ }^{523}$ Directing an attack against a peacekeeping or humanitarian mission constitutes a war crime under Article 8 (2) (b) (iii) of the Statute. ${ }^{524}$ The element had also affected the gravity assessment, because the OTP considered that the attack had disrupted the operations of the mission and thus impacted not only direct and indirect victims, but also the local population. ${ }^{525}$ The PTC had agreed

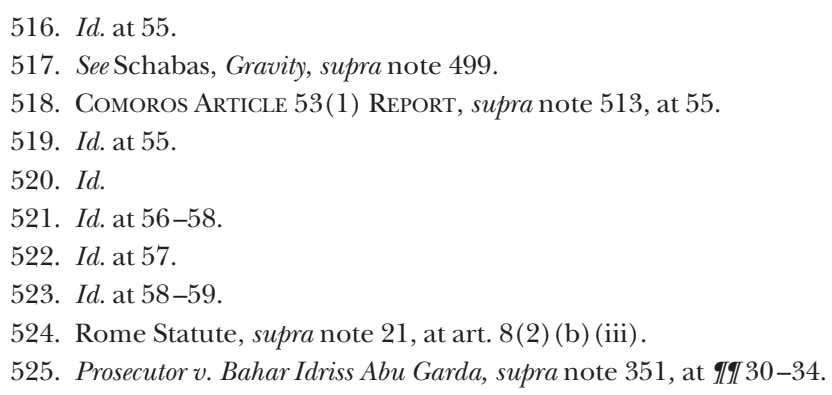


with this assessment. ${ }^{526}$ However, as is apparent from its evaluation of the Situation in Comoros, the OTP appears to have reserved the right to evaluate whether an entity or organization has a humanitarian mission for the purposes of Article 8(2) (b) (iii) and not automatically accept how the entity or organizations defines itself or its mission. ${ }^{527}$

In the Situation in Comoros, the OTP did not reach the same conclusion, despite the fact that the purpose of the flotilla was to deliver humanitarian supplies to the population of Gaza. ${ }^{528}$ It decided this for several reasons, including the perceived lack of neutrality and impartiality of the flotilla, its failure to seek Israeli consent, and the alleged proposal by the Israeli authorities to provide alternate routes for delivering the supplies. The OTP thus found that the flotilla did not constitute a humanitarian mission for the purposes of Article 8 (2) (b) (iii) ${ }^{529}$ For this reason, the impact on the population of Gaza was not considered as an aggravating factor. In conclusion, the OTP found that the gravity criterion was not fulfilled and decided not to proceed. ${ }^{530}$

In accordance with Article 53(3)(a) of the Statute, the Union of Comoros requested a PTC review of the Prosecutor's decision not to prosecute. ${ }^{531}$ Upon review, PTC I disagreed with the OTP's assessment of gravity on a number of points. For example, it disagreed with the notion that facts outside of the Court's jurisdiction, such as the broader context of conflict, could not be considered in the gravity assessment. ${ }^{532}$ Moreover, it came to a different conclusion than the OTP on the scale of the crimes, holding that the number of victims was significant enough to reach the gravity threshold. ${ }^{533}$ In several respects, the PTC found that the OTP had made premature determinations, and that it should have opened a full investigation in order to clarify certain aspects which impacted gravity. ${ }^{534}$ Regarding the impact of crimes on the population of Gaza, the PTC disagreed with the OTP, and addition-

526. As mentioned above in Section VI.B.2(b), the PTC declined to confirm the charges against Abu Garda due to insufficient evidence. Id. at If 233.

527. Comoros Article 53(1) Report, supra note 513, at 59-60.

528. Id.

529. Id. at 57 .

530. Id. at 60-61.

531. Situation on Registered Vessels of Comoros, Greece and Cambodia, ICC-01/13, Decision on the Request of the Union of Comoros to Review the Prosecutor's Decision not to Open an Investigation (July 16, 2015), https://www.icc-cpi.int/CourtRecords/CR2015_13139.pdf.

532. Id. at $\mathbb{1} 17$.

533. Id. at If 26.

534. Id. at II $30,36,43$. 
ally held that an impact beyond direct and indirect victims should not be necessary in order to reach the gravity threshold. ${ }^{535}$

In conclusion, PTC I requested that the OTP reconsider its decision not to investigate the Situation in Comoros. ${ }^{536}$ However, as explained above, the OTP is not required to comply with such a request, because the reviewed decision was not based on the interests of justice. ${ }^{537}$ This demonstrates the significance of prosecutorial discretion when assessing the gravity of situations. Furthermore, the conflicting opinions of the PTC and the OTP demonstrate the flexible nature of the criterion. Though gravity might appear as a strictly legal threshold, the weighing of different factors and circumstances has a clearly discretionary character.

What can then be gathered from the OTP's application of the gravity criterion? Can a strategic choice be deciphered? From the examined practice, the OTP uses the gravity criterion in a relative sense in order to prioritize among situations pressing for its attention. An alternative to this would be to understand gravity in absolute terms, like a fixed threshold similar to a de minimis rule. ${ }^{538}$ This would place the task of selection, like prioritizing and choosing among different possibilities, more in the hands of states, the SC, and senders of Article 15 communications. Taking into account the presumption for the interests of justice, the OTP's relative approach to gravity makes it arguably the most important criterion for prioritizing among several viable situations, and thus central to the role of prosecutorial discretion in situation selection.

The outcome of a comparison of course depends on what is compared. Arguably, situations should be compared with other situations, as in the first Iraq decision. However, the jurisdictional limits of situations such as in Iraq and Comoros mean that they will always fall short when compared to more broadly defined situations. In the Comoros decision, the OTP did not compare with other situations, but with cases. This may make sense considering that a situation is made up

535. Id. at II $47-48$.

536. Id. at II 50 .

537. The OTP has yet to pronounce whether or not it will reconsider its decision on the situation but filed an appeal against the decision by the PTC I. The Appeals Chamber rejected this appeal as inadmissible because it lacked legal grounds. See Situation on Registered Vessels of Comoros, Greece and Cambodia, ICC-01/13, Decision on the Admissibility of the Prosecutor's Appeal Against the Decision on the Request of the Union of the Comoros to Review the Prosecutor's Decision not to Initiate an Investigation (Nov. 6, 2015), https://www.icc-cpi.int/CourtRecords/CR2015_20965. pdf. 538. See deGuzman \& Schabas, supra note 7, at 144. 
of potential cases. In other words, a potential case was compared with an actual case. This seems to have led to a more detailed assessment of gravity factors, such as the impact of crimes on the civilian population. However, the fact that situation selection is more preliminary may complicate the comparison, because the conclusions will not be as well founded as in case selection.

\section{Analysis}

\section{a. Gravity, Neutrality, and Moral Clarity}

The combined impression of the first two strategic choices is that the OTP views gravity as more appropriate to consider than, for example, practical feasibility and potential political ramifications when selecting situations. The rationale seems to be that, as a matter of principle, the gravest situations are the worthiest of the ICC's attention. Such a principle could be linked to the objectives of ending impunity and of preventing crimes. When invoked in the Statute Preamble, these objectives refer to "the most serious crimes of concern to the international community." ${ }^{539}$ However, this could be interpreted as a reference to the subject-matter jurisdiction of the Court rather than to the additional gravity threshold in Article 17(1)(d).

Another possible explanation for the OTP's preference for focusing on gravity in situation selection, rather than the factors associated with the interests of justice, is that gravity is perceived as a more objective and measurable standard. By relying on gravity, the OTP might wish to avoid accusations of politicization, and to underscore its legitimacy as a judicial actor. Such a strategy is suspected, and criticized, by Schabas stating that "gravity provides the prosecutor with a seemingly objective but ultimately an extraordinarily subjective standard." ${ }^{540}$

In a similar vein, Greenawalt links gravity to a concept of "moral clarity," especially with regard to war crimes. ${ }^{541}$ He argues that, while international criminal justice is normally concerned with "deepest moral offenses of human history," not all war crimes are as morally

539. See Rome Statute, supra note 21, pmbl. (“(4) Affirming that the most serious crimes of concern to the international community as a whole must not go unpunished and that their effective prosecution must be ensured by taking measures at the national level and by enhancing international cooperation, (5) Determined to put an end to impunity for the perpetrators of these crimes and thus to contribute to the prevention of such crimes.").

540. Schabas, Selecting Situations and Cases, supra note 33, at 380.

541. Greenawalt, supra note 3, at 633-41. 
unambiguous. ${ }^{542}$ He gives the example of a NATO missile attack against a Serbian media company in 1999, during the war in Kosovo. According to some commentators, this attack violated international humanitarian law. ${ }^{543}$ However, a special committee consulted by the Prosecutor of the ICTY considered it legally acceptable. ${ }^{544}$ Based on this assessment, the ICTY Prosecutor declined to formally investigate it. According to Greenawalt, this demonstrates the legal and moral complexities that can arise when applying the laws of war. He argues that it is reasonable for the ICC to avoid such ambiguous situations, because its focus should be to establish moral clarity rather than invite moral debate. ${ }^{545}$ According to Greenawalt, the OTP's finding of insufficient gravity in the Situation in Iraq was indicative of such an aspiration. This brings to mind the objective of improving respect for international law. Clearly, a pedagogical effect will be easiest for the ICC to achieve if its decisions and rulings are viewed as both legally and morally authoritative. ${ }^{546}$

However, even if the OTP should select situations based on a concept of morality, is gravity really the best measurement of this? In other words, is there a direct correlation between immorality and gravity as understood and applied by the OTP? As Greenawalt points out, another possibly relevant factor is the difficulty of underlying legal determinations, for example, when qualifying an act as criminal under international humanitarian law. ${ }^{547}$ Furthermore, it is questionable to suggest that the OTP's finding of inadmissibility of the Situation in Iraq was based on morality. Is detainee abuse attributed to British troops in Iraq necessarily less immoral than, for example, the recruitment of child soldiers by armed groups in the DRC? As Schabas suggests, the fact that the Situation in Iraq was the result of an aggressive war could have been factored in, in the same way as the wider context of conflict was considered in the Situation in DRC. ${ }^{548}$

The OTP's selection of situations is not, and will likely never be, beyond moral reproach from every perspective. The very fact that the

542. Id. at 636 .

543. See, e.g., Amnesty International, nato/Federal Republic of Yugoslavia 'Collateral Damage' OR Unlawful Killings? (2000).

544. See Int'l Crim. Trib. for the Former Yugoslavia, Final Report to the Prosecutor by the Committee Established to Review the NATO Bombing Campaign Against the Federal RePublic OF YugOSLAVIA, II II 71-79 (2000), http:/ / www.icty.org/x/file/Press/nato061300.pdf.

545. Greenawalt supra note 3 , at $640-\overline{41 .}$

546. See id.

547. Id.

548. Schabas, Gravity, supra note 499, at 245-46. 
OTP's true motives have been questioned shows the ambiguity of the gravity criterion. Though attempts have been made to empirically evaluate situation selection based on gravity, ${ }^{549}$ an element of subjectivity is arguably involved in selecting and weighing the different aspects of this wide concept. Moreover, assuming that all relevant situations are grave per se, the very fact of comparing their gravity might be inherently controversial. If the goal is to appear neutral and to avoid accusations of political bias, it might therefore be better to apply an absolute gravity threshold equally to all situations.

\section{b. Painting a Broad Historical Picture}

In both the Iraq and the Comoros situations, the finding of insufficient gravity was related to the situations' jurisdictional limits. ${ }^{550}$ This gives the impression that the OTP prefers to focus on broader situations, including a higher number of potential cases. Such a preference brings to mind the current strategy of open-ended investigations and applying multiple case hypotheses throughout investigations. ${ }^{551}$ Perhaps the OTP finds it more worthwhile to select situations where it can sustain its attention, rolling out the selection of a high number of cases over time. ${ }^{552}$ This may explain why the broader contexts of conflict in the DRC, Uganda, and CAR were invoked in the first Iraq decision.

A preference of "broad" situations might be beneficial to the objective of creating a historical record of conflicts. It could be argued that the more a conflict is covered by the ICC's jurisdiction, the greater its potential for contributing to the historical record. For example, the ICC may more accurately depict the conflict by lifting crimes committed by several different actors, which, for example, is not presently possible in the Situation in Iraq. However, an obvious counterargument is that the ICC's contribution to a historical record will always be fragmentary. In addition, the OTP's case selection to date does not always indicate a comprehensive approach. For example, in the Situation in CAR, only one case of core ICG crimes has been selected. ${ }^{553}$ Furthermore, the OTP has explicitly stated that it will not necessarily

549. Smeulers et al., supra note 446 (using secondary data from empirical databases on human rights violations to establish a "seriousness index" of countries, which is then compared to the situation selection practice of the OTP).

550. OTP Response to Communications Received Concerning Iraq, supra note 214, at 9; Comoros Article 53(1) Report, supra note 513, at 56-58.

551. OTP Strategic Plan 2012-2015, supra note 121, at 14.

552. See Draft Policy Paper on Case Selection and Prioritization, supra note 324, at 14.

553. Prosecutor v. Gombo, ICC-01/05-01/08, Judgment, If 2 (Mar. 21, 2016). 
prosecute both sides to a conflict, at least not to an equal extent. ${ }^{554}$ In sum, there is little that indicates that the historical objective has been prioritized by the OTP.

\section{c. Conclusions: Recognizing the Need for Selectivity}

If the presumption for the interests of justice has put the role of prosecutorial strategy in situation selection into question, the focus on relative gravity has arguably reaffirmed it. Though the practice in question is limited to two situations, it suffices to show that the OTP will not uncritically move forward with each situation which fulfills minimum Statute requirements. Though the choice constitutes an interpretation of the gravity criterion, it is arguably a strategic one which falls into the sphere of discretion. Alternatively, the OTP could have chosen to apply the criterion as an absolute threshold.

In contrast with the presumption for the interests of justice, which may give the impression that the OTP aspires to universality, the focus on relative gravity reflects more pragmatism. It seems that the OTP wishes to focus its efforts where it can have the most impact. This seems to align with the objective of improving respect for international law. Graver situations, it can be argued, carry the most symbolic value and are, as Greenawalt argues, less morally ambiguous. ${ }^{555}$ Alternatively, it could be seen as an important pedagogical point to uphold the rules of international law even when their application is legally, politically or morally complex. From such a perspective, which might be described as legalistic, it would seem more suitable to construe gravity in absolute terms.

\section{Strategic Choice 3: Focusing on High-Level Perpetrators}

\section{In Policy}

As previously stated, the OTP emphasizes gravity in both situation and case selection. When it comes to case selection, one aspect that has featured prominently in the strategy and policy documents is the level of responsibility of defendants. ${ }^{556}$ This is the first of two elements of

554. Policy Paper on Preliminary Examinations, supra note 158, II 66; Draft Policy Paper on Case Selection and Prioritization, supra note 324, at 7.

555. Greenawalt, supra note 3 , at 530.

556. Paper on SOMe POlicy issues before the OfFice of the Prosecutor, supra note 62, at 6-7; Prosecutorial Strategy 2009-2012, supra note 121, at 5-6; OTP Strategic Plan 2012-2015, supra note 121 , at 13-14. 
gravity identified by the PTCs, the second being the gravity of the crimes as such ${ }^{557}$ Beginning in its very first policy paper, the strategy of the OTP has been to focus on "high-level perpetrators," i.e., those who occupy high-ranking and influential positions within organizations responsible for the commission of crimes, such as states or non-state armed groups. ${ }^{558}$ With the 2013 strategic plan, the focus was broadened to include mid-level, and under some circumstances, even lowlevel perpetrators.

The above-mentioned strategic choice is based on the premise that the most responsible perpetrators of ICC crimes should be targeted. ${ }^{559}$ Moreover, the concept of individual responsibility has been linked to the hierarchical level of a person within a structure, such as a state, army, or armed group. The highest ranking persons are therefore seen as the most desirable objects of prosecution. This approach is common to international criminal tribunals. For the IMT and IMTFE, the selection of "major war criminals" was inscribed in their very mandates. ${ }^{560}$ At the ICTY and ICTR, targeting high-level perpetrators was firstly a matter of prosecutorial strategy. As mentioned earlier, the ICTY Prosecutor also adopted an "upwards-building" strategy. ${ }^{561}$ However, as the tribunals developed completion strategies, the SC formally recommended that their prosecutors focus on the highest ranking perpetrators. ${ }^{562}$ For the OTP, the Appeals Chamber ruling on arrest warrants in the Ntaganda case established that focusing on senior leaders is not mandatory, but discretionary. ${ }^{563}$ This enabled a strategic change presented in 2013.

An obvious problem with terms such as low-, mid-, or high-level perpetrators is that they lack precision. In its 2013 Strategic Plan, the OTP noted that the structures it investigates are not always traditionally

557. See, e.g., Kenya authorization decision, supra note 139, II 59.

558. Prosecutorial Strategy 2009-2012, supra note 121, at 6.

559. Paper on SOMe Policy issues before the Office of the Prosecutor, supra note 62, at 6-7; Prosecutorial Strategy 2009-2012, supra note 121, at 5-6; OTP Strategic Plan 2012-2015, supra note 121, at 13-14; Prosecutorial Strategy 2009-2012, supra note 121, at 6.

560. See IMT Charter, supra note 37, art. 1; IMFTE Charter, supra note 37, art. 1. According to Dominic McGoldrick, the term "major" referred to rank of the defendants rather than to the seriousness of the crimes. See Dominic McGoldrick, Criminal Trials Before International Tribunals: Legality and Legitimacy, in The Permanent International Criminal Court: Legal and Policy Issues 9, 14 (Dominic McGoldrick, Peter Rowe, \& Eric Donnelly eds., 2004).

561. See supra Section VI.B.2.b.

562. See S.C. Res. 1503 (Aug. 28, 2003).

563. Situation in the DRC, Decision on the Prosecutor's Application for Warrants of Arrest, Article 58, Appeals Chamber, supra note 273, III 73-74. 
and hierarchically organized. ${ }^{564}$ This likely further complicates the ranking of potential defendants. Furthermore, the level of individual responsibility of a perpetrator clearly depends on more factors than his or her formal rank or title. For these reasons, the policy of focusing on mid- to high-level perpetrators can hardly be seen as a rigid standard, but rather as a general indicator for case selection. ${ }^{565}$

The strategic change in 2013 was based on the OTP's experience of targeting high-level perpetrators, which had proven practically difficult. By broadening its focus, the Office wished to achieve a higher rate of "success." ${ }^{566}$ The upwards-building strategy means that leaders are still considered the most desirable targets of prosecution. However, the opening toward selecting low-level perpetrators that have committed especially grave or notorious crimes reflects a flexible approach to the importance of "rank." ruling on admissibility in the Ntaganda case, holding that no category perpetrators should be excluded per se from the risk of prosecution. ${ }^{568}$ In a sense, the OTP's broadened focus means that it intends to use the flexibility it was granted by the Appeals Chamber.

\section{In Practice}

Due to its discretionary character, the practice of case selection is somewhat difficult to examine. Publicly available material—such as requests and decisions on arrest warrants, summonses to appear, and the confirmation of charges-do not necessarily include the more strategic reasons for the OTP's choices, falling into the sphere of discretion. In particular, there is no available information on other potential cases that were deselected or deprioritized. However, bearing these reservations in mind, the material does give an indication of the "rank" or level of responsibility of defendants thus far selected.

In the DRC, Uganda, and CAR situations, selected defendants have all belonged to the leadership of non-state armed groups. In the DRC, the OTP selected leaders of armed groups of the military wing of UPC/FPLC (Thomas Lubanga Dyilo and Bosco Ntaganda), ${ }^{569}$ FRPI

564. OTP Strategic Plan 2012-2015, supra note 121, at 13.

565. Cf. Greenawalt, supra note 3 , at 631.

566. OTP Strategic Plan 2012-2015, supra note 121, at 12.

567. See Policy Paper on Sexual and Gender-based Crimes, supra note 323, at 14.

568. Situation in the DRC, Decision on the Prosecutor's Application for Warrants of Arrest, Article 58 , Appeals Chamber, supra note 273, II 74.

569. Prosecutor v. Dyilo, ICC-01/04-01/06, Document Containing the Charges, II $4-5$ (Aug. 28 2006). 
(Germain Katanga), ${ }^{570}$ FNI (Mathieu Ngudjolo Chui), ${ }^{571}$ and FDLR (Callixte Mbarushimana and Sylvestre Mudacumura). ${ }^{572}$ In Uganda, the leadership of the LRA was targeted: Joseph Kony, Vincent Otti, Okot Odhiambo, Raska Lukwiya, and Dominic Ongwen. ${ }^{573}$ In the Situation in CAR, the leader of Congolese armed group/political party MLC, Jean-Pierre Bemba Gombo, was selected. ${ }^{574}$ Out of the mentioned defendants, five have been the top leaders of their respective organizations: Lubanga, Katanga, Ngudjolo Chui, Kony, and Bemba Gombo. The rest have held high ranking and influential positions, such as Executive-Secretary (Mbarushimana), top military commander (Mudacumura) or senior commander (Odhiambo, Lukwiya, and Ongwen).

In Darfur, Kenya, Libya, and Côte d'Ivoire, the OTP's focus has been on rather high-ranking government representatives, including four heads of state: Omar Al-Bashir of Sudan, ${ }^{575}$ Uhuru Kenyatta of Kenya, ${ }^{576}$ Muammar Gadaffi of Libya, ${ }^{577}$ and Laurent Gbagbo of Côte d'Ivoire. ${ }^{578}$ Other defendants have held high-ranking government positions such as Minister of State for the Interior (Ahmad Harun in Sudan), ${ }^{579}$ Head of the Public Service and Secretary to the Cabinet (Francis Muthaura in Kenya), ${ }^{580}$ Minister for Youth, Vocational Train-

570. Prosecutor v. Katanga, ICC-01/04-01/07, Warrant of Arrest, 5 (July 2, 2007).

571. Prosecutor v. Chui, ICC-01/04-02/07, Warrant of Arrest, 5 (July 6, 2007).

572. Prosecutor v. Mbarushimana, ICC-01/04-01/10, Warrant of Arrest, III 8-9 (Sept. 28 2010); Prosecutor v. Mudacumura, ICC-01/04-01/12, Decision on the Prosecutor's Application Under Article 58, I 64 (July 13, 2012).

573. Prosecutor v. Joseph Kony, supra note 271, If 7; Prosecutor v. Otti, ICC-02/04, Warrant of Arrest, If 10, (July 8, 2005); Prosecutor v. Ongwen, ICC-02/04, Warrant of Arrest, If 9 (July 8, 2005).

574. Prosecutor v. Gombo, ICC-01/05-01/08, Warrant of Arrest, III 18-19 (May 23, 2008).

575. Prosecutor v. Al Bashir, ICC-02/05-01/09, Warrant of Arrest for Omar Hassan Ahmad Al Bashir, 6-7 (Mar. 4, 2009).

576. See Prosecutor v. Muthaura, ICC-01/09-02/11, Decision on the Prosecutor's Application for Summonses to Appear (Mar. 8, 2011).

577. Prosecutor v. Gaddafi, ICC-01/11, Decision on the Prosecutor's Application Pursuant to Article 58 as to Muammar Mohammed Abu Minyar Gadaffi, Saif Al-Islam Gadaffi and Abdullah Al-Senussi, Il 17 (June 27, 2011).

578. Prosecutor v. Gbagbo, ICC-01/11-01/11, Decision on the Confirmation of Charges, II 78, 79, 96 (June 12, 2014).

579. Prosecutor v. Harun, ICC-02/05-01/07, Warrant of Arrest for Ahmad Harun, 5 (Apr. 27, 2007).

580. See Prosecutor v. Muthaura, ICC-01/09-02/11, Decision on the Prosecutor's Application for Summonses to Appear (Mar. 8, 2011). 
ing and Employment (Charles Blé Goudé in Côte d'Ivoire), ${ }^{581}$ Head of Military Intelligence (Abdullah Al-Senussi in Libya), ${ }^{582}$ and de facto prime minister (Saif Al-Islam Gadaffi in Libya) ${ }^{583}$ Besides government actors, prosecutions have also targeted leaders of non-state actors such as the Sudanese Janjaweed militia leader Ali Kushayb ${ }^{584}$ and leaders of the armed opposition group Justice and Equality Movement (JEM) Abu Garda ${ }^{585}$ and Abdallah Banda. ${ }^{586}$ In the Situation in Mali, the one case so far initiated concerns Ahmad Al Faqi Al Mahdi, a member of the Tuareg militia Ansar Dine and leader of a brigade within that militia. ${ }^{587}$

Bearing in mind the limitations of this overview, the OTP's practice clearly seems to reflect a focus on high-level perpetrators, not least through the selection of several heads of state and top leaders of armed groups. At the very least, all defendants seem to fall within the range of mid- to high-level perpetrators, holding positions of considerable influence, both de jure and de facto, within their respective organizations. Because most cases were initiated prior to 2013, when the OTP announced its strategic shift, the effects of this shift mostly remain to be seen. The only case that has been initiated since then is the Al Faqi case in the Situation in Mali. ${ }^{588}$ Indeed, Al Faqi does stand out because he is not referred to a senior or high-ranking leader of his organization, but merely a member, albeit leading a "sub-group" in the form of a brigade ${ }^{589}$ It remains to be seen whether the OTP will continue with an upwards-building strategy in the Situation in Mali.

\section{Analysis}

\section{a. Ending Impunity for the Most Powerful}

One justification for the focus on high-level perpetrators would be that leaders within an organization are by definition more morally responsible than their subordinates for the crimes attributed to that

581. Prosecutor v. Goudé, ICC-02/11-02/11, Decision on the Confirmation of Charges, II 58-60 (Dec. 11, 2014).

582. Gaddafi, supra note 577, at II 67.

583. Id.

584. Harun, supra, note 579 at 5 .

585. Prosecutor v. Garda, ICC-02/05-02/09, Summons to Appear, II 17 (May 7, 2009).

586. Prosecutor v. Nourain, ICC-02/05-03/09, Summons to Appear, Il 17 (Aug. 27, 2009).

587. Prosecutor v. Al Mahdi, ICC-01/12-01/15, Mandat d'arrêt [Warrant of Arrest], If 7 (Sept. 18, 2015).

588. The arrest warrant was issued in September 2015. See id.

589. Id. If 7 . 
organization. In some cases, it can of course be discussed if the planning or ordering of crimes is necessarily more immoral than their physical execution. ${ }^{590}$ Arguably, this may depend on such factors as the leaders' actions and the clarity of the causal links to the actions of subordinates, However, it might be argued that regardless of this, the prosecution of leaders is likely to have the greatest symbolic value, and therefore contribute more to improving respect for international law. ${ }^{591}$ It is an important point that the law applies even to the most powerful. Because these figures are often major players in conflicts, prosecuting them will likely also be favorable to the objective of contributing to a historical record.

A problem with targeting high-level leaders is that they can be more difficult to apprehend and convict, as the al-Bashir and Kenyatta cases demonstrate. ${ }^{592}$ Moreover, their prosecution is more likely to cause political controversy. From the perspective of ending impunity, it might be argued that the OTP should focus on cases with a higher probability of success and thus maximize the chances of as many convictions as possible. On the other hand, it seems plausible that leaders of states or organizations, and in particular leaders of states, are especially likely to enjoy impunity on the national level. Therefore, prosecution at the ICC can arguably be an important contribution to the objective of ending impunity. Such an idea is reflected in the 2003 policy paper, suggesting a sort of burden-sharing arrangement whereby national justice systems would prosecute lower-level perpetrators. ${ }^{593}$ Therefore, the more pragmatic upward-building strategy, combined with a principal goal of reaching high-level perpetrators, appears to be a well-balanced approach.

\section{b. Avoiding a Singular Focus}

As discussed in relation to the objective of preventing crimes, some argue that high-ranking perpetrators are less likely than others to be deterred by the risk of prosecution. ${ }^{594}$ However, as Greenawalt points out, to the extent that a deterrent effect can be achieved, it will likely have a broader and more significant impact with respect to leaders

\footnotetext{
590. See Damaška, supra note 67, at 351-53; Morris, supra note 117, at 186.

591. See Greenawalt, supra note 3, at 629.

592. OTP Strategic Plan 2012-2015, supra note 121, at 13.

593. Paper on SOME POlicy issues Before the Office of the Prosecutor, supra note 62, at 6-7. 594. See supra Section IV.B.
} 
than to less influential perpetrators. ${ }^{595}$ Besides deterrence, the effects of individual incapacitation will likely be more significant. For example, prosecuting a political leader might aid political transition simply by removing him or her from power. ${ }^{596}$

In its ruling on admissibility in the Ntaganda case, the Appeals Chamber held that excluding any category of perpetrators from the risk of prosecution would be detrimental to the objective of prevention. ${ }^{597}$ Similarly, Gustavo Gallón argues that both leaders and subordinates must be prosecuted, because both categories are replaceable. ${ }^{598}$ In other words, only prosecuting leaders will not suffice, because new leaders can emerge from among the subordinates. ${ }^{599}$ Furthermore, Gallón argues that an exclusive focus on leaders is an oversimplification of reality. While it may be tempting to see a leader as "the key element [] to explain every violations," the truth is that large-scale violations often require a high degree of decentralization. ${ }^{600}$ This argument brings to mind the objective of creating a historical record. Even granted that the ICC's contribution to such a record will be fragmentary, it should arguably attempt to present a reasonably accurate picture, and therefore avoid an exaggerated focus that might even be historically misleading.

In a similar vein, Madeline Morris argues that a broad focus on both leaders and their subordinates, rather than a narrow focus on leaders, will benefit the objective of providing redress to victims. ${ }^{601}$ While leaders may bear the greatest responsibility on an overarching level, individual victims may find a greater sense of justice in their direct perpetrators being held accountable. ${ }^{602}$ However, if the ambition would be to satisfy a large number of victims on this "individual" level, a correspondingly large number of perpetrators would likely have to be prosecuted. ${ }^{603}$ Morris recognizes that in this respect, the OTP is limited by resource constraints. Yet, she argues that even with a limited number of cases, the best would be to prosecute "a full cross section of

595. Greenawalt, supra note 3, at 629. See also Olásolo, supra note 6, at 146.

596. Olásolo, supra note 6 , at 146.

597. Situation in the DRC, Decision on the Prosecutor's Application for Warrants of Arrest, Article 58, Appeals Chamber, supra note 273, II $73-79$.

598. Gallón, supra note 56, at 98.

599. See also Morris, supra note 117, at 188.

600. Gallón, supra note 56, at 98.

601. Morris, supra note 117, at 188.

602. Id. at $186-87$.

603. Id. at $186-88$. 
perpetrators," ranging from high- to low-level. ${ }^{604}$ In that way, the legitimate interests of victims would be recognized, at least on a symbolic level. This reasoning is quite convincing. The OTP's current upwards-building strategy is positive in this respect, though it would seem that it is based on more practical considerations of the prospects of convicting leaders.

\section{c. Conclusions: A Principally and Pragmatically Reasonable Approach}

Like the focus on relative gravity in situation selection, the focus on high-level perpetrators in case selection reflects a recognition of the need for selectivity. In other words, the strategic choice is based on an assessment of how the OTP can put its limited time and resources to their most effective use. In terms of contributing to the ICC's objectives, it seems that the strategic choice could be beneficial in several ways. A primary focus on high-level leaders holds a symbolic and pedagogical value that may contribute to improving respect for norms. If successful, it would also be a symbolically important contribution to the fight against impunity. Precisely for this reason, it seems reasonable to apply a pragmatic approach to the targeting of leaders, i.e., the upwards-building strategy. Moreover, not excluding middle- and lowlevel perpetrators might also be beneficial to the objectives of prevention and of providing redress to victims. In sum, attempting to select a somewhat representative cross section of perpetrators, while maintaining a primary focus on leaders, appears reasonable from both a principal and a pragmatic point of view.

\section{CONCLusion}

The establishment of a permanent international criminal court has been hailed as one of the great achievements in the history of international criminal justice. Most likely, its future will largely be determined by the direction the Court takes. The paradox of the ICC is that its capacity is exceptionally limited in relation to its broad mandate and lofty ambitions. Therefore, it is crucial that the selection of situations and cases is exercised in a well-calculated and strategic manner. In this respect, prosecutorial strategy is key. Against this background, the purpose of this study has been to identify strategic choices of the OTP, and to discuss how they relate to the ICC's objectives.

604. Id. at 188 . 
The first strategic choice, the presumption for the interests of justice, gives the impression that the OTP is downplaying its own discretion. After a closer look, it appears that the purpose is rather to emphasize the legalistic and apolitical character of prosecutorial decision-making. For situation selection, the effect is more significant, and means that considerations of a more pragmatic character are essentially left to states, the SC and/or senders of Article 15 communications. This fact sheds a particular light on the second strategic choice, relative gravity in situation selection. This arguably represents a more pragmatic approach to situation selection. Though using the seemingly objective gravity criterion also reflects an element of legalism, it means that the practical need for selectivity is recognized. The third strategic choice, the selection of high-level perpetrators, follows a similar logic of placing emphasis on gravity. Moreover, the modification of the strategy shows the more clearly pragmatic approach that the OTP has adopted to case selection than to situation selection.

In sum, the three strategic choices demonstrate the tensions between legalism and pragmatism in prosecutorial decision-making. The need for predictability and legal certainty on the one hand, and for pragmatism and case-by-case flexibility on the other hand, must be a familiar dilemma to most prosecutors. However, for the ICC OTP the balancing act seems particularly difficult. As a legal institution operating in highly politicized contexts, it might be particularly important for the ICC to stand for legalistic values. It could even be argued that this is the Court's main function. At the same time, precisely the fact that the Court operates within complex and widely varying contexts, combined with the fact that it has limited resources and is largely dependent on the cooperation of states, creates many practical difficulties. If the Court is to be perceived as both legitimate and effective, a good balance between legalism and pragmatism will likely need to be found. Indeed, the task of the Prosecutor is not an easy one.

The balancing of legalism and pragmatism can also be linked to the different objectives of the ICC. The more principal objectives of ending impunity, preventing crimes, and providing redress to victims seem to inspire a legalistic view, primarily demonstrated by the presumption for the interests of justice. However, in view of the ICC's limited capacity and practical difficulties, these objectives should arguably be seen as more of long-term aspirations than as realistic objectives. The objective of improving respect for norms is perhaps more realistic, in the sense that it hinges more on the symbolic value than on the quantity of 
investigations and prosecutions. ${ }^{605}$ The focus on gravity, both in situation and in case selection, seems to fall in line with this objective.

In comparison with the aforementioned objectives, the objectives of restoring peace and security and of contributing to a historical record seem somewhat secondary to the OTPs strategic choices. This can likely be explained by the fact that they are wide political and societal goals to which the contribution of the ICC, and of criminal prosecution in general, will necessarily be limited. In the words of Hannah Arendt, from her famous account of the 1961 trial against Nazi leader Adolf Eichmann in Israel:

[T] he purpose of a trial is to render justice, and nothing else; even the noblest ulterior purposes ... can only detract from the law's main business: to weight the charges brought against the accused, to render judgment, and to mete out due punishment. $^{606}$

The question on what role a court can or should play for the attainment of wider political and societal goals is especially interesting in the case of the ICC. Because previous international tribunals have been established within specified political and societal contexts, their founders were able to assess the prospects of international criminal justice having positive impacts, such as contributing to ending conflict, promoting reconciliation, or creating a historical record. ${ }^{607}$ With the establishment of the ICC, the control over assessing the appropriateness of investigations and prosecution has to a large extent been left in the hands of the Prosecutor. ${ }^{608}$ The underlying rationale for this seems to be that criminal prosecution is positive per $s e$, regardless of specific political and societal circumstances. This also seems to fall in line with a universal concept of human rights. ${ }^{609}$

Luc Reydams and Jed Odermatt have suggested that in fact, the ICC is an objective unto itself-its main function being the institutionalization and depoliticization of international criminal justice. ${ }^{610}$ The OTP's interpretation of its own mandate as apolitical seems to fall in line with such a view. So does the approach of basing selectivity on, at least

\footnotetext{
605. See Damaška, supra note 67, 345-47.

606. Hannah Arendt, Eichmann in Jerusalem: A Report on the Banality of Evil 253 (2006).

607. See Reydams \& Odermatt, supra note 32, at 111-12.

608. Id. at 108 .

609. See supra section VII.A.3.c.

610. Reydams \& Odermatt, supra note 32, at 111-12.
} 
seemingly, objective legal criteria like gravity. There is great symbolic and principal value to such an approach. The very existence and functioning of an international criminal court, operating as far as possible like a domestic court, could go a long way in terms of strengthening the rule of law on a global scale.

However, the desired effect will likely require that the OTP's decisionmaking is perceived as objective and consistent. If not, questions of hidden motives, political or otherwise, will undoubtedly continue to arise. ${ }^{611}$ After examining the OTP's strategy and policy documents, the recurrent call for more transparency in this respect appear reasonable ${ }^{612}$ While "more candour about criteria," as James Goldston has called it, ${ }^{613}$ may not help in guiding concrete decisions, it would arguably have an inherent value-potentially strengthening respect for the very concept of international legal institutions and their discretionary powers.

611. See Schabas, Victor's Justice, supra note 3, at 548-49; Greenawalt, supra note 3, at 641; Al Jazeera, Arab Leaders Snub Al-Bashir Warrant, supra note 436; Dec. 245 (XIII) Rev.1, supra note 436.

612. Danner, supra note 1, at 541-52; Goldston, supra note 2, at 402-05; Greenawalt, supra note 3 , at 652 .

613. See Goldston, supra note 2. 